\title{
Annual Site Environmental Report for Tonopah Test Range, Nevada and Kauai Test Facility, Hawaii
}

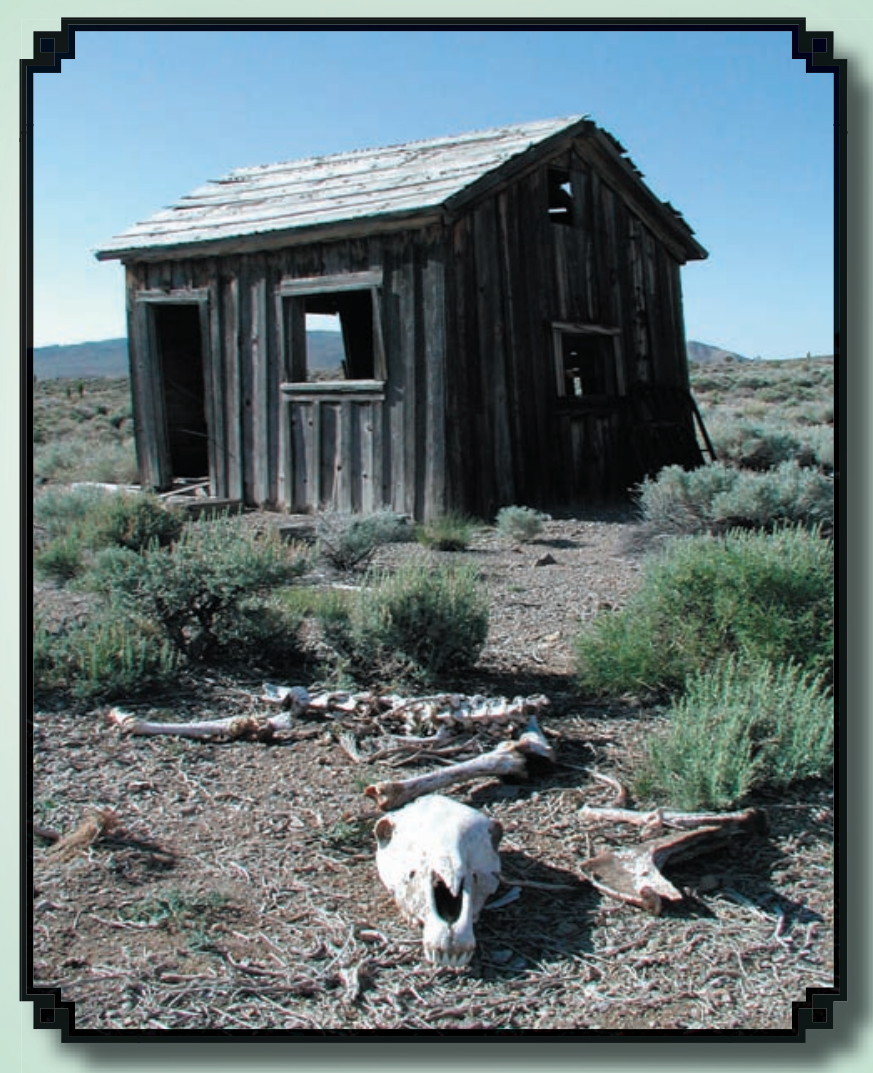

Katrina Wagner, Susan Koss, Stephanie Salinas, Teresa Goering and Amber Montoya

Prepared by

Sandia National Laboratories

Albuquerque, New Mexico 87185

Sandia is a multiprogram laboratory operated by Sandia Corporation, a Lockheed Martin Company, for the United States Department of Energy's National Nuclear Security Administration under Contract DE-AC04-94A185000.

Approved for public release; further dissemination unlimited. 
Issued by Sandia National Laboratories, operated for the United States Department of Energy by Sandia Corporation.

NOTICE: This report was prepared as an account of work sponsored by an agency of the United States Government. Neither the United States Government, nor any agency thereof, nor any of their employees, nor any of their contractors, subcontractors, or their employees, make any warranty, express or implied, or assume any legal liability or responsibility for the accuracy, completeness, or usefulness of any information, apparatus, product, or process disclosed, or represent that its use would not infringe privately owned rights. Reference herein to any specific commercial product, process, or service by trade name, trademark, manufacturer, or otherwise, does not necessarily constitute or imply its endorsement, recommendation, or favoring by the United States Government, any agency thereof, or any of their contractors or subcontractors. The views and opinions expressed herein do not necessarily state or reflect those of the United States Government, any agency thereof, or any of their contractors.

Printed in the United States of America. This report has been reproduced directly from the best available copy.

Available to DOE and DOE contractors from

U.S. Department of Energy

Office of Scientific and Technical Information

P.O. Box 62

Oak Ridge, TN 37831

Telephone: $\quad$ (865)576-8401

Facsimile: $\quad$ (865)576-5728

E-Mail: reports@adonis.osti.gov

Online ordering: http://www.osti.gov/bridge 
SAND 2005-4628

Unlimited Release

Printed September 2005

\title{
Calendar Year 2004 \\ Annual Site \\ Environmental Report \\ Tonopah Test Range, Nevada \& \\ Kauai Test Facility, Hawaii
}

\author{
Project Lead \\ Stephanie Salinas \\ Associate Chief Editor and Document Specialist \\ Katrina Wagner \\ Graphics and Document Specialist \\ Susan Koss \\ Document Production Team \\ Teresa Goering and Amber Montoya \\ Produced by: \\ Sandia National Laboratories \\ P.O. Box 5800 \\ Albuquerque, New Mexico 87185-1042
}

\begin{abstract}
Tonopah Test Range (TTR) in Nevada and Kauai Test Facility (KTF) in Hawaii are government-owned, contractor-operated facilities operated by Sandia Corporation, a subsidiary of Lockheed Martin Corporation. The U.S. Department of Energy (DOE), National Nuclear Security Administration (NNSA), through the Sandia Site Office (SSO), in Albuquerque, NM, manages TTR and KTF's operations. Sandia Corporation conducts operations at TTR in support of DOE/NNSA's Weapons Ordnance Program and has operated the site since 1957. Westinghouse Government Services subcontracts to Sandia Corporation in administering most of the environmental programs at TTR. Sandia Corporation operates KTF as a rocket preparation launching and tracking facility. This Annual Site Environmental Report (ASER) summarizes data and the compliance status of the environmental protection and monitoring program at TTR and KTF through Calendar Year (CY) 2004. The compliance status of environmental regulations applicable at these sites include state and federal regulations governing air emissions, wastewater effluent, waste management, terrestrial surveillance, and Environmental Restoration (ER) cleanup activities. Sandia Corporation is responsible only for those environmental program activities related to its operations. The DOE/NNSA, Nevada Site Office (NSO) retains responsibility for the cleanup and management of ER TTR sites. Currently, there are no ER Sites at KTF. Environmental monitoring and surveillance programs are required by DOE Order 450.1, Environmental Protection Program (DOE 2005) and DOE Order 231.1A, Environment, Safety, and Health Reporting (DOE 2004b).
\end{abstract}


Calendar Year 2004 Annual Site Environmental Report

Sandia National Laboratories, Tonopah Test Range, Nevada \&

Kauai Test Facility, Hawaii

Final Approval date: August 2005

Work performed under Contract No. DE-ACO4-94AL85000

\section{Prepared for:}

U.S. Department of Energy, National Nuclear Security Administration Sandia Site Office, Albuquerque, NM

\section{Prepared by:}

Sandia Corporation, Albuquerque, New Mexico

ES\&H and Emergency Management Center

Environmental Management Department (6331) 


\section{ACKNOWLEDGMENTS}

We wish to thank the following individuals who contributed their time and expertise assisting in the production of the TTR and KTF annual reports:

Karen Agogino
Brenda Bailey-White
Linda Bayliss
Joe Bonaguidi
Kevin Cabble
Michael du Mond
Charles Fink

Karen Agogino

Brenda Bailey-White

Linda Bayliss

Charles Fink

\author{
Lucie Mayeux \\ Mark Miller \\ Amber Montoya \\ Jennifer Payne \\ Stephanie Salinas \\ Rebecca Sanchez \\ Katrina Wagner
}

\section{NOTE TO THE READER}

The goals for the TTR and KTF Annual Site Environmental Reports are to present summary environmental performance, compliance with environmental standards and requirements, and to highlight significant facility programs. In addition, DOE views this document as a valuable tool for maintaining a dialogue with our community about the environmental health of these sites.

We are striving to improve the quality of the contents as well as include information that is important to you. Please provide feedback, comments, or questions to:

U.S. Department of Energy

National Nuclear Security Administration

Sandia Site Office

P.O. Box 5400

Albuquerque, NM 87185-5400

Attention: Karen Agogino 
This page intentionally left blank. 


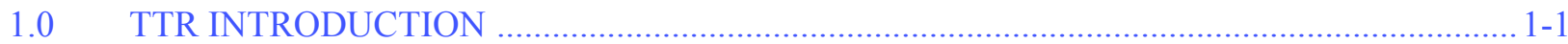

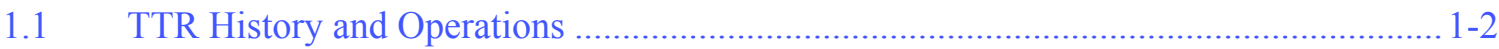

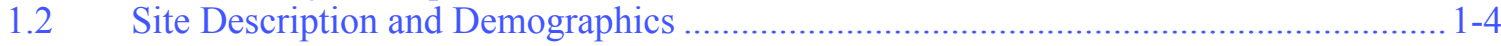

1.3 Regional Geology, Hydrology, Climate, and Fauna .................................................. 1-5

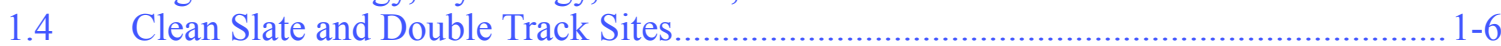

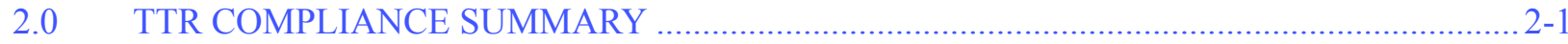

2.1 Compliance Status with Federal Regulations .............................................................2-2

2.1.1 Comprehensive Environmental Response, Compensation, and Liability Act (CERCLA) ........................................................................ 2-2

2.1.2 Emergency Planning and Community Right-to-Know Act (EPCRA) ................ 2-2

2.1.3 Resource Conservation and Recovery Act (RCRA) .........................................2-2

2.1.4 Federal Facility Compliance Act (FFCA) ......................................................... 2-2

2.1.5 Clean Air Act (CAA) and Clean Air Act Amendments (CAAA) of 1990 .......... 2-4

2.1.6 Clean Water Act (CWA) ............................................................................... 2-4

2.1.7 Safe Drinking Water Act (SDWA) ....................................................... 2-5

2.1.8 Toxic Substances Control Act (TSCA) ............................................................ 2-5

2.1.9 Federal Insecticide, Fungicide, and Rodenticide Act (FIFRA) ........................ 2-5

2.1.10 National Environmental Policy Act (NEPA) …................................................ 2-5

2.1.11 Endangered Species Act (ESA) ….............................................................. 2-5

2.1.12 Migratory Bird Treaty Act (MBTA) ……................................................... 2-6

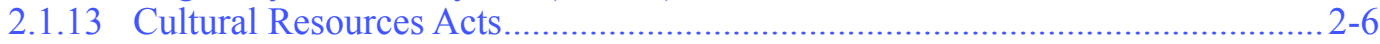

2.1.14 Environmental Compliance Executive Orders (EOs) .......................................2-6

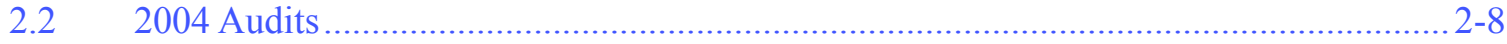

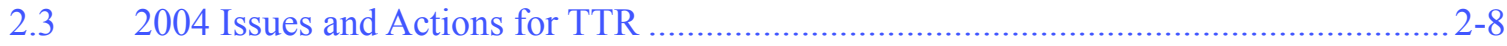

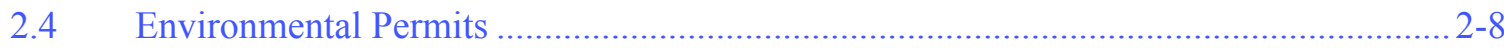

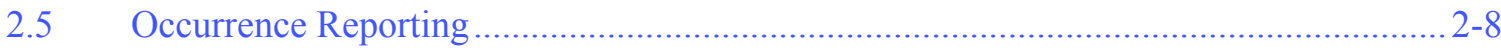

3.0 TTR ENVIRONMENTAL PROGRAMS INFORMATION .................................................. 3-1

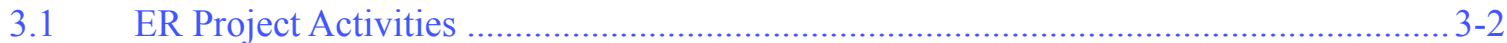

3.2 Waste Management Programs .................................................................................. 3-6

3.3 Spill Prevention Control and Countermeasures (SPCC) Plan ......................................... 3-6

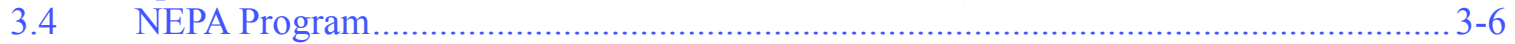

3.5 Environmental Monitoring Performed by Outside Agencies .......................................... 3-8

3.6 Summary of Release Reporting .............................................................................. 3-8

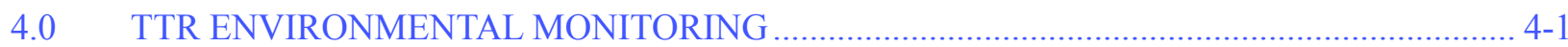

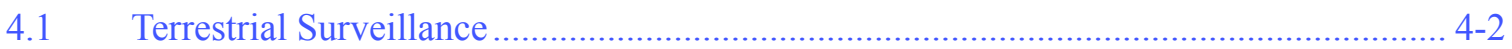

4.1.1 Program Objectives ................................................................................... 4-2

4.1.2 Regulatory Standards and Comparisons ........................................................ 4-2

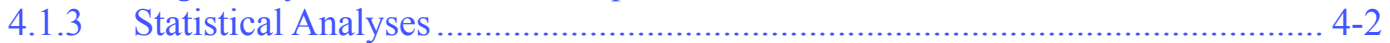

4.1.4 Sampling Locations ...................................................................................... 4-3

4.1.5 Radiological Parameters and Results .......................................................... 4-3

4.1.6 Non-Radiological Parameters and Results .......................................................... 4-7

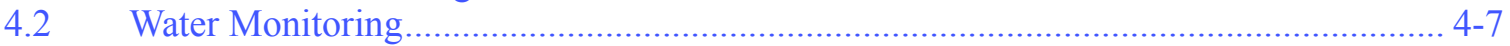

4.2.1 Production Well Monitoring ........................................................................... 4-7

4.2.2 Sewage System and Septic Tank Monitoring ..................................................... 4-8

4.2.3 Storm Water Monitoring ................................................................................. 4-9 


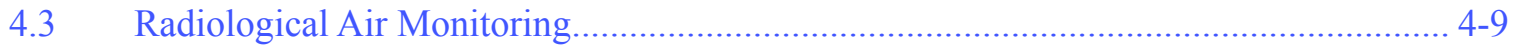

4.4 Non-Radiological Air Emissions ................................................................................... 4-10

5.02004 ANNUAL SITE ENVIRONMENTAL REPORT FOR KAUAI TEST FACILITY ............ 5-1

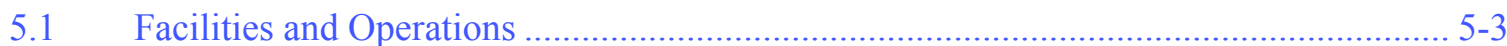

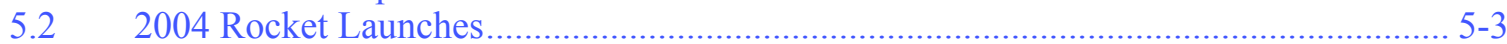

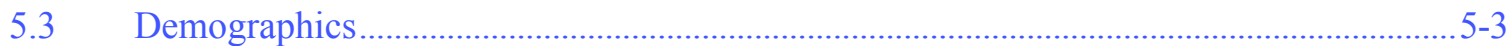

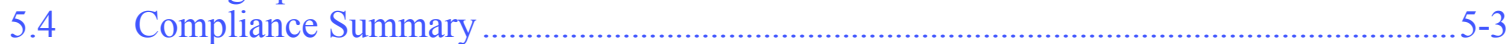

5.5 Environmental Program Activities .......................................................................... 5-10

5.6 Environmental Surveillance and Monitoring Activities ............................................. 5-11

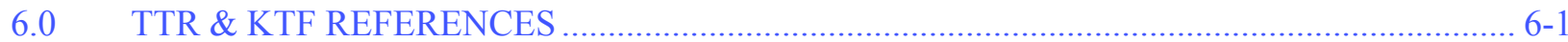

APPENDIX A Terrestrial Surveillance Results and Sampling Location Maps for TTR.................... A-1

\section{FIGURES}

1-1 Location of the Tonopah Test Range (TTR), Within the Boundaries of the

Nevada Test and Training Range (NTTR), Nevada .................................................................. 1-3

1-2 Location of Facilities Operated by SNL/NSO at TTR ......................................................... 1-6

4-1 Tonopah Test Range TLD Exposure (1999-2004) .................................................................... 4-8

5-1 Map of the Pacific Missile Range Facility (PMRF) and the Adjacent Area................................. 5-2

\section{TABLES}

1-1 Project Roller Coaster Test Information.............................................................................. 1-7

2-1 2004 SARA Title III (or EPCRA) Reporting Requirements Applicable to TTR ...................... 2-4

2-2 Protected Species Potentially Occurring in Nye County, Nevada............................................ 2-7

2-3 Summary of Environmental Audits Performed at TTR in 2004 .............................................. 2-9

2-4 2004 Summary of Permit Ownership at TTR ....................................................................... 2-9

3-1 DOE/NNSA/NSO ER Project TTR CAUs and CASs Calendar Year 2004 Status...................... 3-3

3-2 Sandia Corporation TTR Generated RCRA-Regulated

Hazardous Waste Shipped Off-site in 2004 ........................................................................... 3-7

3-3 Non-RCRA-Regulated Hazardous or Toxic Waste Shipped Off-site in 2004 .......................... 3-7

3-4 Recycled Regulated Hazardous or Toxic Waste Shipped Off-site in 2004 ............................. 3-7

4-1 Decision Matrix for Determining Priority Action Levels ....................................................... 4-3

4-2 On-site Terrestrial Surveillance Locations at TTR ............................................................... 4-4

4-3 Off-site Terrestrial Surveillance Locations at TTR …....................................................... 4-4

4-4 Perimeter Terrestrial Surveillance Locations at TTR .................................................... 4-5

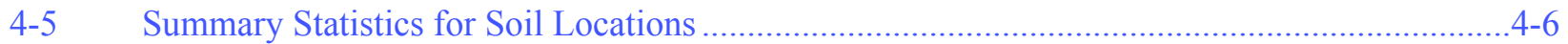

4-6 Summary Statistics for Soil Locations Noted as Priority-2 .................................................... 4-7

4-7 Summary Statistics for Soil Locations Noted as Priority-3 ................................................... 4-7

4-8 Summary Statistics for TLDs by Location Class ................................................................. 4-7

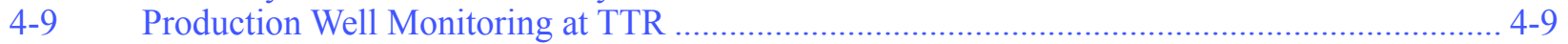

4-10 Calculated Dose Assessment Results for On-site Receptor ................................................... 4-10

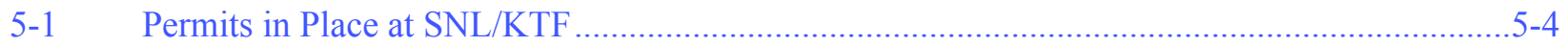

5-2 2004 SARA Title III (or EPCRA) Reporting Requirements Applicable to SNL/KTF ...............5-6

5-3 Threatened and Endangered Species Potentially Occurring on SNL/KTF ...............................5-7

6-1 State of Nevada Administrative Code (NAC) Applicable to the TTR ..................................... 6-8 
ACRONYMS AND ABBREVIATIONS

A AEA

ACM

AEC

AIRFA

AQC

ARPA

ASER

AST

B BLM

BMD

BMDO

BMP

BSA

C CAA

CAAA

CAS

CAU

CEMP

CERCLA

CFR

CIS

COD

CV

CWA

CY

D D\&D

DMR

DoD

DOE

DOE/AL

DOH

DRI

DU

E EA

EDE

EHS

EIS

EM

EMS

EO

EPA

EPCRA

ER

ERDA

ES\&H

ESA

F $\quad$ FFCA

FFACO

FIDLER

FIFRA

FONSI
Atomic Energy Act

Asbestos Containing Material

U.S. Atomic Energy Commission

American Indian Religious Freedom Act

Air Quality Compliance

Archaeological Resources Protection Act

Annual Site Environmental Report

aboveground storage tank

U.S. Bureau of Land Management

Ballistic Missile Defense

Ballistic Missile Defense Organization

Best Management Practice

Bulk Storage Areas

Clean Air Act

Clean Air Act Amendments

Corrective Action Site

Corrective Action Unit

Community Environmental Monitoring Program

Comprehensive Environmental Response, Compensation, and Liability Act

Code of Federal Regulations

Chemical Inventory System

chemical oxygen demand

Coefficient of Variation

Clean Water Act

calendar year

decontamination and demolition

Discharge Monitoring Report

U.S. Department of Defense

U.S. Department of Energy

U.S. Department of Energy, Albuquerque Operations Office

Department of Health

Desert Research Institute, Water Resource Center, University of Nevada System

depleted uranium

environmental assessment

effective dose equivalent

extremely hazardous substance

Environmental Impact Statement

Environmental Management (Department)

Environmental Management System

Executive Order

U.S. Environmental Protection Agency

Emergency Planning and Community Right-to-Know Act

Environmental Restoration

U.S. Energy Research and Development Administration

Environment, Safety, and Health

Endangered Species Act

Federal Facilities Compliance Act

Federal Facilities Agreement and Consent Order

field instrument for the detection of low-energy radiation

Federal Insecticide, Fungicide, and Rodenticide Act

Finding of No Significant Impact 
FTU-1 Flight Test Unit 1

$\begin{array}{lll}\text { H } & \text { HAR } & \text { Hawaii Administrative Rules } \\ \text { HQ } & \text { headquarters }\end{array}$

I ICP-20 Inductively Coupled Plasma-20 (stable metals)

ICP-AES Inductively Coupled Plasma-Atomic Emission Spectrum

IDW Investigation Derived Waste

IOC Inorganic Compounds

ISMS Integrated Safety Management System

J JASSM Joint Air to Surface Stand-off Missile System

JTA Joint Test Assembly

K KTF Kauai Test Facility

L LDR Land Disposal Restriction

LLW low-level waste

M MBTA Migratory Bird Treaty Act

MDA minimum detectable activity

MOA Memorandum of Agreement

MEI maximally exposed individual

MSDS Material Safety Data Sheet

MW mixed waste

N NAEG Nevada Applied Ecology Group

NAFB Nellis Air Force Base (Range Complex)

NCR no code required

NEDS Non Explosive Destruction Site

NDEP Nevada Department of Environmental Protection

NEPA National Environmental Policy Act

NESHAP National Emission Standards for Hazardous Air Pollutants

NFA No Further Action

NFEC National Facilities Engineer Command

NHPA National Historic Preservation Act

NNSA National Nuclear Security Administration

NOS not otherwise specified

NPDES National Pollutant Discharge Elimination System

NPL National Priorities List

N/R Not required

NSP Non-covered Source Permit

NSPS New Source Performance Standard

NSO Nevada Site Office

NTS Nevada Test Site

NTTR Nevada Test and Training Range

NV Nevada

$\begin{array}{lll}\mathbf{O} & \text { O\&M } & \text { Operations and Maintenance } \\ \text { OIG } & \text { Office of Inspector General }\end{array}$

P PA Preliminary Assessment

PCB polychlorinated biphenyl

$\mathrm{pH} \quad$ potential of Hydrogen

PMRF Pacific Missile Range Facility

PMS portable monitoring station

PPE personal protective equipment

PSD Prevention of Significant Deterioration 


\begin{tabular}{|c|c|c|}
\hline $\mathbf{Q}$ & QA & quality assurance \\
\hline $\mathbf{R}$ & $\begin{array}{l}\text { RBIFF } \\
\text { R\&D } \\
\text { RCRA } \\
\text { ROD } \\
\text { RQ } \\
\text { RY }\end{array}$ & $\begin{array}{l}\text { Reentry Body Impact Fuze Flight } \\
\text { research and development } \\
\text { Resource Conservation and Recovery Act } \\
\text { Record of Decision } \\
\text { Reportable Quantity } \\
\text { reporting year }\end{array}$ \\
\hline $\mathbf{S}$ & $\begin{array}{l}\text { SAIC } \\
\text { SARA } \\
\text { SDI } \\
\text { SDWA } \\
\text { SHPO } \\
\text { SNL/KTF } \\
\text { SNL/NM } \\
\text { SOC } \\
\text { SPCC } \\
\text { SSO } \\
\text { STARS } \\
\text { SVOC }\end{array}$ & $\begin{array}{l}\text { Science Applications International Corporation } \\
\text { Superfund Amendments and Reauthorization Act } \\
\text { Strategic Defense Initiative } \\
\text { Safe Drinking Water Act } \\
\text { State Historic Preservation Office } \\
\text { Kauai Test Facility } \\
\text { Sandia National Laboratories, New Mexico } \\
\text { Synthetic Organic Compounds } \\
\text { Spill Prevention, Control, and Countermeasures } \\
\text { Sandia Site Office } \\
\text { Strategic Targeting System } \\
\text { semi-volatile organic compound }\end{array}$ \\
\hline $\mathbf{T}$ & $\begin{array}{l}\text { TLD } \\
\text { TQ } \\
\text { TRPH } \\
\text { TRI } \\
\text { TSCA } \\
\text { TSD } \\
\text { TTR }\end{array}$ & $\begin{array}{l}\text { thermoluminescent dosimeter } \\
\text { threshold quantity } \\
\text { total recoverable petroleum hydrocarbon } \\
\text { Toxic Release Inventory } \\
\text { Toxic Substances Control Act } \\
\text { treatment, storage, and disposal (facility) } \\
\text { Tonopah Test Range }\end{array}$ \\
\hline $\mathbf{U}$ & $\begin{array}{l}\text { UDP } \\
\text { USAF } \\
\text { USFS } \\
\text { USGS } \\
\text { UST } \\
\text { UXO }\end{array}$ & $\begin{array}{l}\text { underground discharge point } \\
\text { U.S. Air Force } \\
\text { U.S. Forest Service } \\
\text { U.S. Geological Survey } \\
\text { underground storage tank } \\
\text { unexploded ordnance }\end{array}$ \\
\hline & VOC & volatile organic compound \\
\hline
\end{tabular}

\section{Units of Measure}

$\begin{array}{llll}{ }^{\circ} \mathrm{C} & \text { Celsius degree } & \mathrm{m} & \text { meter } \\ \mathrm{cm} & \text { centimeter } & \mathrm{m}^{2} & \text { square meter } \\ { }^{\circ} \mathrm{F} & \text { Fahrenheit degree } & \mathrm{m}^{3} & \text { cube meter } \\ \mathrm{ft} & \text { feet } & \mathrm{mg} & \text { milligram } \\ \mathrm{g} & \text { gram } & \mathrm{mi} & \text { mile } \\ \mathrm{in} . & \text { inch } & \mathrm{ppm} & \text { parts per million } \\ \mathrm{km} & \text { kilometer } & \mathrm{yd} & \text { yard } \\ \mathrm{kg} & \text { kilogram } & \mathrm{yr} & \text { year } \\ \mathrm{lb} & \text { pound } & \mathrm{Std} \text { Dev } & \text { standard deviation }\end{array}$

\section{Radioactivity Measurements}

\begin{tabular}{|c|c|c|c|}
\hline $\begin{array}{l}\mathrm{Ci} \\
\mathrm{mrem} \\
\mathrm{mrem} / \mathrm{yr}\end{array}$ & $\begin{array}{l}\text { curie (unit of radioactivity) } \\
\text { millirem (unit of radiation dose) } \\
\text { millirem per year }\end{array}$ & $\begin{array}{l}\mathrm{pCi} / \mathrm{g} \\
\mathrm{rem}\end{array}$ & $\begin{array}{l}\text { picocurie per gram } \\
\text { roentgen equivalent man } \\
\text { (unit of radiation dose) }\end{array}$ \\
\hline
\end{tabular}




$\begin{array}{llll}\mathrm{mR} / \mathrm{yr} & \text { milliroentgen per year } & \mathrm{mSv} & \begin{array}{l}\text { millisievert (unit of radiation dose) } \\ \mathrm{pCi}\end{array} \\ \mu \mathrm{R} / \mathrm{hr} & \text { micocurie } & \mu \mathrm{g} / \mathrm{m}^{2} & \text { microgram per square meter }\end{array}$

\section{Chemical Abbreviations}

$\begin{array}{llll}\mathrm{Am}-241 & \text { americium-241 } & \mathrm{Cs}-137 & \text { cesium-137 } \\ \mathrm{Pu}-238 & \text { plutonium-238 } & \mathrm{Pu}-239 & \text { plutonium-239 } \\ \mathrm{Pu}-240 & \text { plutonium-240 } & \mathrm{U}_{\text {tot }} & \text { uranium, total }\end{array}$

\section{Approximate Conversion Factors for Selected SI (Metric) Units}

$\begin{array}{ll}\text { Multiply Si (metric) unit } & \text { by } \\ \text { Celsius }\left({ }^{\circ} \mathrm{C}\right) & { }^{\circ} \mathrm{F}=9 / 5{ }^{\circ} \mathrm{C}+32 \\ \text { centimeter }(\mathrm{cm}) & 0.39 \\ \text { cubic meter }\left(\mathrm{m}^{3}\right) & 35 \\ \text { gram }(\mathrm{g}) & 0.035 \\ \text { hectare }(\mathrm{ha}) & 2.5 \\ \text { kilogram }(\mathrm{kg}) & 2.2 \\ \text { kilometer }(\mathrm{km}) & 0.62 \\ \text { liter }(\mathrm{L}) & 0.26 \\ \text { meter }(\mathrm{m}) & 3.3 \\ \text { milligram per liter }(\mathrm{mg} / \mathrm{L}) & 1 \\ \text { microgram per gram }(\mathrm{mg} / \mathrm{g}) & 1 \\ \text { square kilometer }\left(\mathrm{km}^{2}\right) & 0.39\end{array}$

To obtain U.S. customary unit

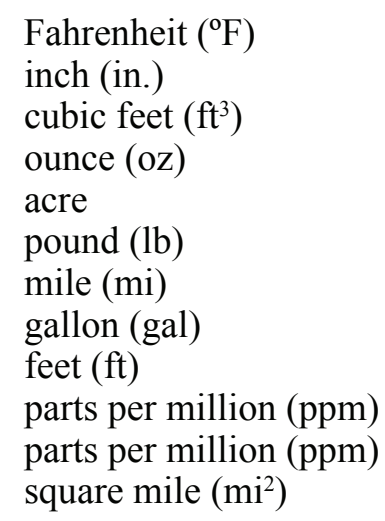




\section{TTR \& KTF}

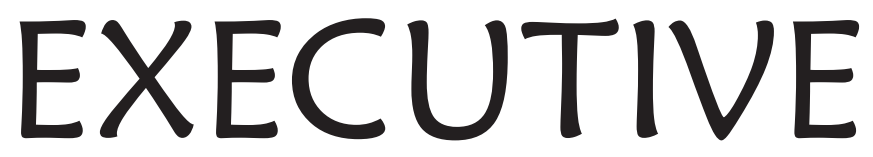

SUMMARY

Tonopah Test Range

Environmental Programs:

Waste Management

Environmental Restoration

Project

Terrestrial Surveillance

Water Quality

Air Quality

National Environmental

Policy Act Activities

Kauai Test Facility

Environmental Programs

National Environmental

Policy Act Activities

Water Quality

Air Quality

Terrestrial Surveillance
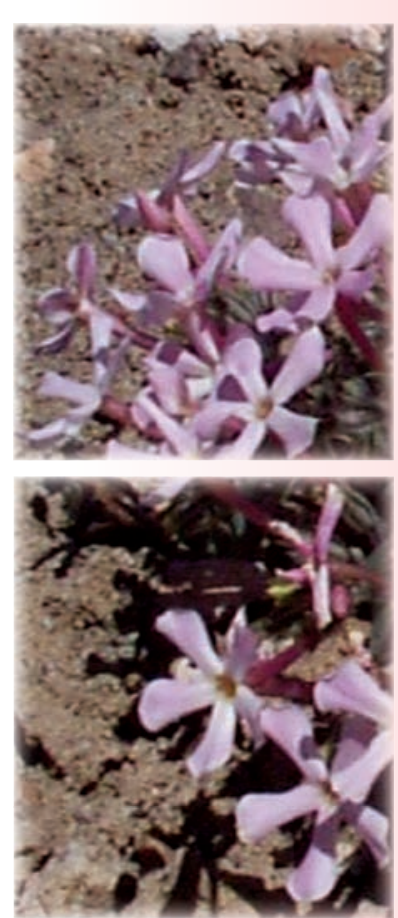
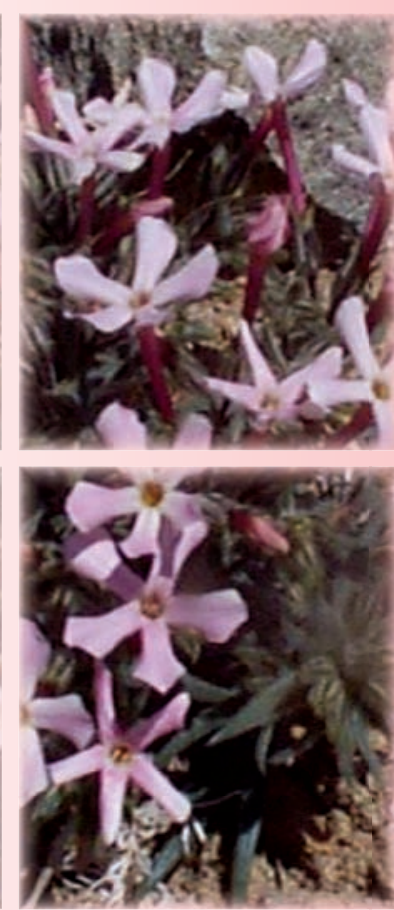

Longleaf Phlox

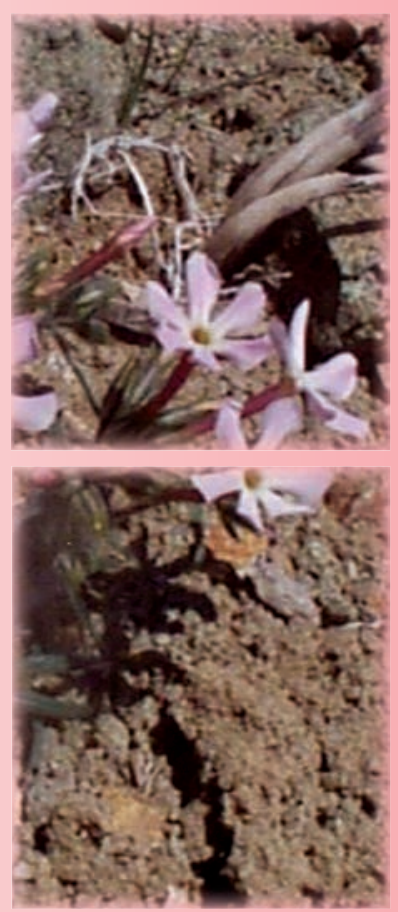


Sandia National Laboratories (SNL) (a whollyowned subsidiary of Lockheed Martin Corporation) at Tonopah Test Range (TTR) and Kauai Test Facility (KTF) are government-owned, contractoroperated facilities owned by the U.S Department of Energy (DOE), National Nuclear Security Administration (NNSA) and managed by the Sandia Site Office (SSO), in Albuquerque, New Mexico. This report was prepared in accordance with, and as required, by DOE Order 450.1, Environmental Protection Program (DOE 2005) and DOE Order 231.1A, Environment, Safety, and Health Reporting (DOE 2004b). This report summarizes data from environmental protection and monitoring programs at TTR and KTF for Calendar Year 2004. It also discusses Sandia Corporation's compliance with environmental statutes, regulations, and permit provisions and highlights other significant environmental programs and efforts at TTR and KTF. This report is a key component of Sandia Corporation and DOE's effort to keep the public informed about environmental conditions throughout the DOE/ NNSA complex.

\section{Tonopah Test Range}

Sandia Corporation conducts operations at TTR in support of the DOE/NNSA's Weapons Ordnance Program. Sandia Corporation's activities involve research and development and testing of weapon components and delivery systems. Many of these activities require a remote test range with a long flight corridor for air drops and rocket launches. Other activities include explosive tests and gun firings.

\section{Environmental Programs}

The following environmental programs are in place at TTR:

- Waste management,

- Environmental Restoration(ER),

- Terrestrial surveillance,

- Water quality monitoring,

- Air quality compliance, and

- National Environmental Policy Act (NEPA).

\section{Waste Management}

Waste generated at TTR in 2004 included hazardous waste regulated by the Resource Conservation and Recovery Act (RCRA) and non-hazardous industrial and sanitary waste. All hazardous waste was shipped to permitted treatment, storage, and disposal facilities. (Sandia Corporation does not handle waste generated by ER activities.)

\section{ER Project}

ER activities at TTR are conducted through the DOE/NNSA, Nevada Site Office (NSO). ER sites remaining at TTR include areas contaminated from target tests and detonations, non-impacted surface debris, and areas impacted by ordinance and depleted uranium.

\section{Terrestrial Surveillance}

Soil samples were collected from 14 off-site, eight perimeter, and 21 on-site locations in 2004. Soil is the only terrestrial medium sampled at TTR. Samples are collected to detect airdeposited pollutants or contaminants that may have transported and deposited as a result of surface water runoff.

Thermoluminescent dosimeter results (a measure of ambient gamma radiation) showed no distinguishable statistical difference between on-site and off-site locations in 2004. Nonradiological soil analyses were not performed in 2004. To date, there have been no terrestrial sample results that have indicated a significant level of concern (Priority-1) that would trigger actions at locations that are not already being addressed by the ER Project.

\section{Water Ouality}

Wastewater monitoring results confirmed that all permit conditions set by the State of Nevada were met in 2004.

Water quality samples are routinely taken from Production Well 6, which supplies potable water for Sandia Corporation's Main Compound at TTR.

\section{Air Ouality}

Radiological air emissions are regulated by National Emission Standards for Hazardous Air Pollutants. The only radionuclide sources at TTR are the three Clean Slate Sites, which are sources of diffused radionuclide emissions as a result of the re-suspension of contaminated soils. These sites are currently being addressed by DOE/NNSA/NSO under the ER Project. The calculated dose for the maximally exposed individual was 0.024 millirem/ year (mrem/yr), which is approximately 400 times less than the $10 \mathrm{mrem} / \mathrm{yr}$ standard set by the U.S. 
Environmental Protection Agency. Based on this value, an annual dose assessment is not required to be calculated for the TTR site.

TTR's Class II Air Quality Permit requires emission reports from significant non-radionuclide sources. At TTR, these sources include the screening plant and portable screen. In 2004, the total emissions to the state of Nevada were .002 ton/yr from the portable screen replacement.

\section{$\underline{N E P A}$}

At TTR, NEPA compliance is coordinated between Sandia Corporation and DOE/NNSA/SSO. Compliance is also supported with the assistance of the Desert Research Institute, a branch of the University of Nevada System. A total of six NEPA reviews were processed during 2004. Two NEPA reviews were completed by SNL/NM. Four NEPA checklists were submitted to SSO for review. Three of these checklists were found to be categorically excluded, and one NEPA checklist is pending a decision at SSO.

\section{Kauai Test Facility}

KTF is operated by Sandia Corporation as a rocket preparation, launching, and tracking facility for DOE/NNSA, as well as in support of other U.S. Military agencies. SNL/KTF exists as a facility within the boundaries of the U.S. Department of Defense Pacific Missile Range Facility. SNL/KTF, located on the island of Kauai at the north end of the Pacific Missile Range Facility near Nohili Point, has been an active rocket-launching facility since 1962. There were no rockets launched from SNL/KTF in 2004.
The following environmental programs are in place at KTF:

- Air quality compliance,

- NEPA,

- Water quality monitoring, and

- Terrestrial surveillance (every five years).

\section{Air Ouality}

As required by the EPA, the 2004 Annual Fee and Monitoring Report (air emissions) was submitted to the State of Hawaii at the end of February 2005 (SNL 2005b). In 2004, the total usage reported to the State of Hawaii was 4,736 gallons of diesel fuel. Sandia Corporation was in compliance with all air quality regulations in 2004.

\section{$\underline{N E P A}$}

At KTF, NEPA compliance is coordinated between Sandia Corporation and DOE/NNSA/SSO. In 2004, Sandia National Laboratories/New Mexico (SNL/NM) completed one NEPA compliance review for proposed actions at $\mathrm{SNL} / \mathrm{KTF}$.

\section{Water Ouality}

Septic tanks do not require permitting or sampling, but as a best management practice, Sandia Corporation periodically performs sampling. No contaminants were identified above the reporting limits.

\section{Terrestrial Surveillance}

Terrestrial surveillance is conducted every five years. No sampling occurred this year. 
This page intentionally left blank.

S-4 


\section{chapter one}

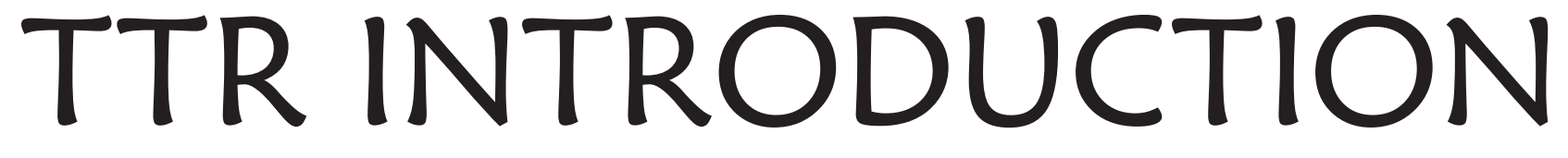

In This Chapter ...

TTR History and Operations

Site Description and Demographics

Regional Geology, Hydrology,

Climate, and Fauna

Clean Slate and Double Track Sites

\section{Environmental Snapshot}

The topography at TTR is

characterized by a broad, flat, valley bordered by two north and south trending mountain ranges. Elevations within TTR range from 5,347 feet at the valley floor to 7,482 feet at Cactus Peak.

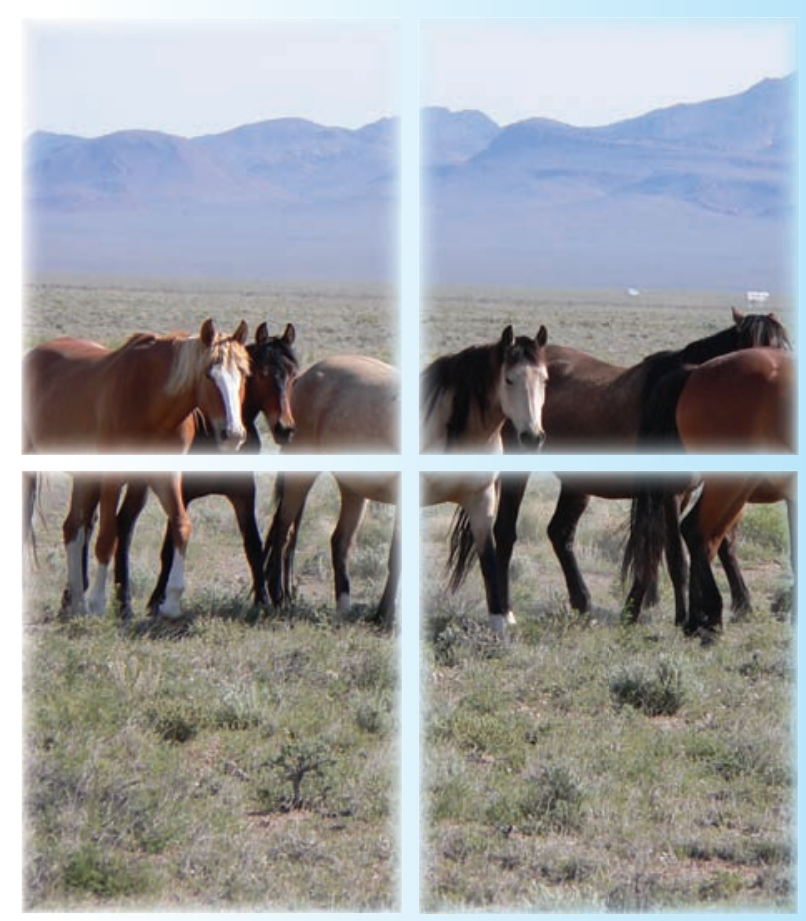

Wild Horses at TTR 
Sandia Corporation (a subsidiary of Lockheed Martin Corporation through its contract with the U.S. Department of Energy [DOE]), National Nuclear Security Administration (NNSA), Sandia Site Office (SSO), operates the Tonopah Test Range (TTR) in Nevada.

Sandia Corporation's TTR is located on approximately 280 square miles $(179,200$ acres $)$ within the boundaries of the Nevada Test and Training Range (NTTR) withdrawal and is used to support DOE/ NNSA and U.S. Air Force (USAF) activities and missions. TTR is owned by the DOE/NNSA, and is managed by the SSO in Albuquerque, New Mexico. Westinghouse Government Service performs most environmental program functions on behalf of Sandia Corporation, including environmental media sampling, wastewater effluent and drinking water monitoring, spill response, and waste management operations. Westinghouse Government Service also supports TTR during tests by operating optics equipment, recovering test objects, and performing radiography.

This Annual Site Environmental Report (ASER) is prepared in accordance with the following DOE Orders that pertain to environmental protection and management:

- DOE Order 231.1A, Environment, Safety, and Health Reporting (DOE 2004b);

- DOE Order 231.1-2, Occurrence Reporting and Processing of Operations Information (DOE 2003);

- DOE Order 435.1, Chg 1, Radioactive Waste Management (DOE 2001);

- DOE Order 450.1, Environmental Protection Program (DOE 2005);

- DOE Order 5400.5, Chg 2, Radiation Protection of the Public and the Environment (DOE 1993); and

- SEN-22-90, DOE Policy on Signatures of RCRA Permit Applications (DOE 1990).

This ASER summarizes data from environmental protection and monitoring programs at TTR for 2004. The environmental programs summarized include waste management, air, water, terrestrial monitoring and surveillance, the Environmental Restoration (ER) Project, and the National Environmental Policy Act (NEPA). DOE Order 450.1 specifies the requirements for environmental monitoring conducted at and around the TTR site. The ASER represents an important component of DOE and Sandia Corporation's effort to keep the public informed about environmental conditions at DOE/ NNSA facilities.

Sandia Corporation's strategy for managing and implementing its Environment, Safety, and Health (ES\&H) Program is described in the Integrated Safety Management System (ISMS). The ISMS program is structured around five safety management functions and provides the processes to assist line management in identifying and controlling hazards. Sandia Corporation is implementing an Environmental Management System (EMS) as an enhancement of the ISMS. The EMS is that part of the ISMS that addresses environmental consequences of SNL/NM's activities, products, and services. In 2004, SNL/NM continued to work to improve environmental management (EM) based on best management practices (BMPs), bench marking, and process improvements.

\subsection{TTR HISTORY AND OPERATIONS}

In 1940, President Roosevelt established the "Las Vegas Bombing and Gunnery Range" (now referred to as NTTR), which is part of the Nellis Air Force Base (NAFB) Complex. The NAFB Complex, located eight miles north of Las Vegas, Nevada, includes several auxiliary small arm ranges, and the NTTR - divided into a North Range and a South Range (Figure 1-1). The Nevada Test Site (NTS) is located between these two ranges. The entire NAFB Complex is comprised of approximately three million acres. TTR is located 32 miles (mi) southeast of Tonopah, Nevada.

\section{TTR Site Characteristics}

The topography at TTR is characterized by a broad, flat, valley bordered by two north and south trending mountain ranges: the Cactus Range to the west (occurring mostly within the boundaries of TTR) and the Kawich Range to the east. Cactus Flat is the valley floor where the main operational area of TTR is located. An area of low hills outcrops in the south. Elevations within TTR range from 5,347 feet at the valley floor to 7,482 feet at Cactus Peak. The elevation within the town of Tonopah is 6,030 feet.

\section{TTR Site Selection}

TTR was selected as a bombing range after similar facilities at the Salton Sea Test Base in California, as well as Yucca Flat on the NTS, became inadequate. By the mid-1950s, the atmosphere at the Salton Sea Test Base became permeated with haze, which limited visibility and hampered photography. Nevada's Yucca Flat site also became inadequate 


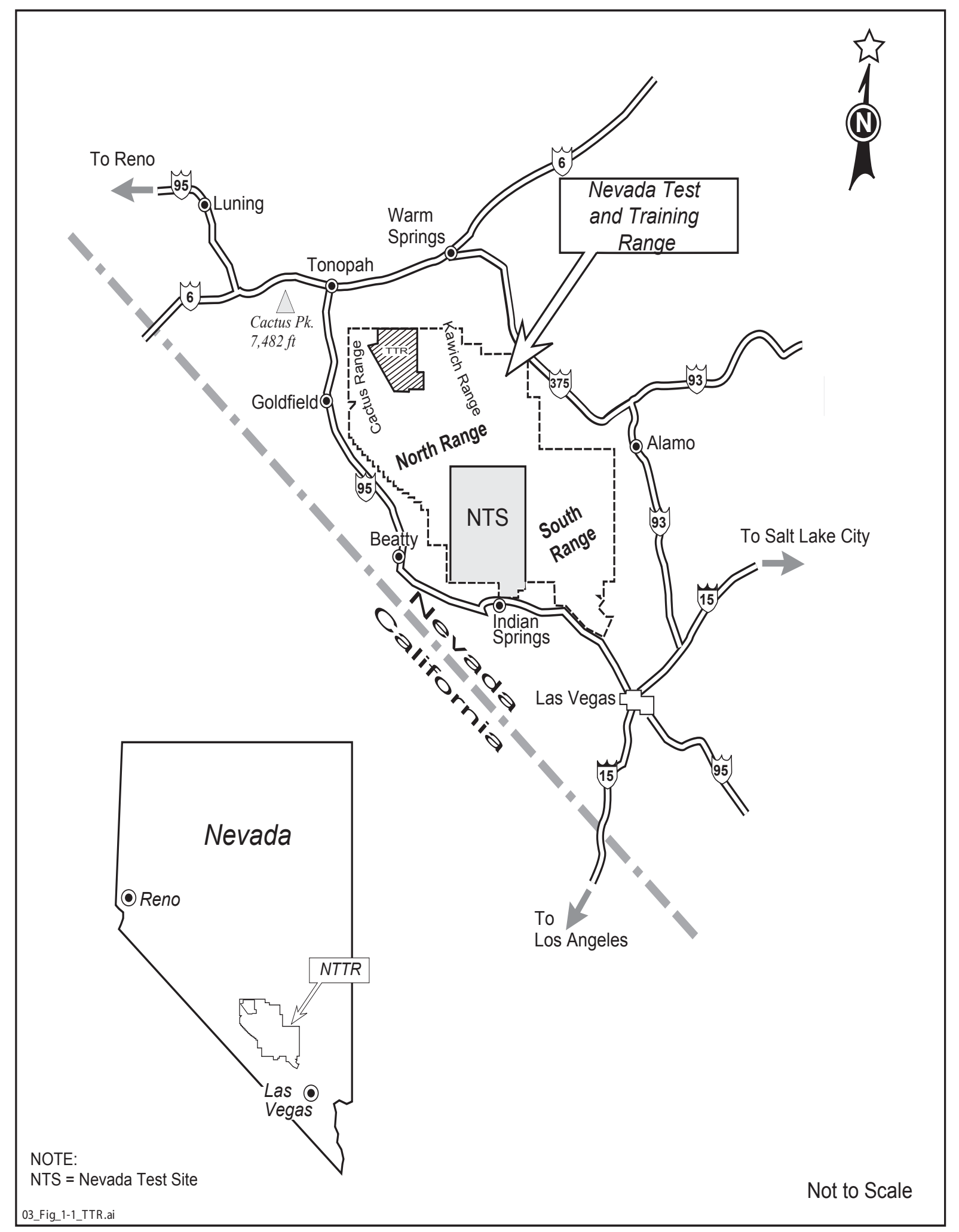

FIGURE 1-1. Location of the Tonopah Test Range (TTR), Within the Boundaries of the Nevada Test and Training Range (NTTR), Nevada. 
due to the increasing emphasis on low-altitude approaches and deliveries that required flat terrain and a long approach corridor. The TTR site was located in the northwest corner of the then Las Vegas Bombing and Gunnery Range. The site, which was approximately seven times the size of the Salton Sea Test Base, was well suited because it had immense areas of flat terrain needed for the increasing use of rockets and low-altitude, high-speed aircraft operations. The area was withdrawn in 1956 and TTR became operational in 1957 to operate and test new weapon systems. In the years following World War II, facilities that were built at TTR were originally designed and equipped to gather data on aircraft delivered inert test vehicles under U.S. Atomic Energy Commission (AEC) cognizance (now DOE). Over the years, the facilities and capabilities at TTR were expanded to accommodate tests related to the DOE/NNSA's Weapons Ordnance Program.

\section{Operations Control Center}

The Main Compound in Area 3 is the heart of the test range activities. The Operations Control Center controls and coordinates all test functions and affords a 360-degree view of the site. During test operations, the test director, range safety officer, test project engineer, camera controller, and range communicator operate the consoles in the Operations Control Center to control and coordinate all test functions.

\section{TTR Activities}

Principal DOE activities at TTR include stockpile reliability testing; research and development (R\&D) testing support of structural development; arming, fusing and firing systems testing; and testing nuclear weapon delivery systems. No nuclear devices are tested at TTR.

TTR is instrumented with a wide array of signal tracking equipment including video, high-speed cameras, radar tracking devices used to characterize ballistics, aerodynamics, and parachute performance on artillery shells, bomb drops, missiles, and rockets.

In recent years, specific test activities at TTR have consisted of the following:

- $\quad$ Air drops (trajectory studies of simulated weapons);

- Gun firings;

- Ground-launched rockets (study of aeroballistics and material properties);

- $\quad$ Air-launched rockets (deployed from aircraft);
- $\quad$ Explosive testing (e.g., shipping and storage containers);

- Static rocket tests (related to the Trident Submarine Program); and

- Ground penetrator tests.

These activities require a remote range for both public safety and to maintain national security. The majority of test activities at TTR occur within Cactus Flat, a valley with almost no topographical relief flanked by mountains and hills.

\section{Site Responsibility}

On October 1, 1997, a Memorandum of Agreement (MOA) was signed between DOE/SSO and the DOE/ Nevada Site Office (NSO) in regards to operational test activities at TTR (DOE 1994). It was determined that $\mathrm{DOE} / \mathrm{SSO}$ is responsible for the oversight of TTR; however, DOE/NSO will continue with the oversight of ER activities at TTR. Environmental program management, as discussed in this ASER, is a joint effort between Sandia Corporation's TTR and Sandia National Laboratories, NM (SNL/NM) employees and contractors with oversight from DOE/SSO. In April 2002, a Land Use Permit was signed between the USAF and NNSA entitled, "Department of the Air Force Permit to the National Nuclear Security Administration To Use Property Located On The Nevada Test and Training Range, Nevada." The current size of TTR is approximately 280 square miles (179,200 acres). Prior to the April 2002 lease agreement, the footprint was 335,655 acres.

\subsection{SITE DESCRIPTION AND DEMOGRAPHICS}

TTR is located within the NTTR at the northern boundary. The area north of the TTR boundary is sparsely populated public lands administered by both the U.S. Bureau of Land Management (BLM) and the U.S. Forest Service (USFS). The land is currently used to graze cattle. There is a substantial irrigated farming operation to the north of the range as well. To the east of TTR, and within the NTTR, is the Nevada Wild Horse Range, which is also administered by the BLM.

The nearest residents are located in the town of Goldfield (population 659), approximately 22 miles west of the site boundary. The town of Tonopah (population 4,400) is approximately 30 miles northwest of the site (DOC 2005). Las Vegas, Nevada is 140 miles from TTR. The total population within a 50-miles radius around TTR is approximately 7,000 , which includes the potential population at TTR if all housing units at the site were occupied. 


\subsection{REGIONAL GEOLOGY, HYDROLOGY, CLIMATE, AND FAUNA}

\section{Geology}

The regional area around TTR is located in the western part of the Basin and Range geophysical province. This area is marked by horst and graben topography, a system of mountains and downdropped fault valleys formed through regional extension. TTR lies northeast of the Walker Lane, a zone of transcurrent faulting and shear, and the Las Vegas Valley shear zone to the southeast (Sinnock 1982).

The Cactus Range to the west of TTR is the remnants of a major volcanic center consisting of relatively young (six million-year-old) folded and faulted tertiary volcanics. This range is one of at least five northwest trending, raised structural blocks that lie along the Las Vegas Valley-Walker Lane lineaments (ERDA 1975).

\section{Surface Water}

Drainage patterns within and near TTR are intermittent (ephemeral stream channels) and end in closed basins. Ephemeral streams occasionally carry spring runoff to the center of Cactus Flat where there is a string of north-south trending dry lakebeds; however, due to the high rate of evaporation, little is recharged to the groundwater (DRI 1991).

There are several small springs within the Cactus and Kawich Ranges. Three springs occur within TTR boundaries: Cactus, Antelope, and Silverbow Springs. Water from these springs does not travel more than several tens of meters dissipating rapidly through evaporation and infiltration. The effect on the landscape is purely local.

\section{Groundwater}

TTR obtains its water from local wells. The U.S. Geological Survey (USGS) has recorded groundwater depths from 21 to 454 feet at the site. Groundwater is encountered at the Antelope Mine well in the Cactus Range at 21 feet and at the EH2 well near the TTR Airport at 454 feet. The depth to groundwater at the Area 9 well located at the north end of the site is approximately 131 feet. South of the Area 9 well, groundwater is encountered at 361 to 394 feet in Area 3. The static water level at the main water supply well (Well 6) is approximately 350 feet.

\section{Climate}

The climate at TTR is typical of high desert, midlatitude locations, with large diurnal and seasonal changes in temperature, and little total rainfall.
Temperature extremes on the test range can vary from a high near $40{ }^{\circ} \mathrm{C}\left(104{ }^{\circ} \mathrm{F}\right)$ in the summer and approach $-30{ }^{\circ} \mathrm{C}\left(-22^{\circ} \mathrm{F}\right)$ in the winter. July and August are the hottest months with daily highs ranging from 32 to $37^{\circ} \mathrm{C}\left(90 \mathrm{~s}{ }^{\circ} \mathrm{F}\right)$ and temperatures between 10 and $15^{\circ} \mathrm{C}\left(50 \mathrm{~s}^{\circ} \mathrm{F}\right)$ at night. January conditions vary from highs 5 to $10^{\circ} \mathrm{C}\left(40 \mathrm{~s}^{\circ} \mathrm{F}\right)$ to lows -7 to $-11^{\circ} \mathrm{C}$ (teens ${ }^{\circ} \mathrm{F}$ ). An eight-year climatology developed from data taken in the 1960s identifies a record high of $38.8^{\circ} \mathrm{C}\left(102^{\circ} \mathrm{F}\right)$ and a record low of $-31^{\circ} \mathrm{C}\left(-24^{\circ} \mathrm{F}\right)$ (Schaeffer 1970).

Rainfall, though sparse, is dependent on elevation. Annual average rainfall on the desert floor is 4 inches with as much as 12 inches falling in the mountains (USAF 1999).

Winds are generally from the northwest in the winter and early spring, switching to southerly directions during the summer. The mountain/valley system channels the wind so that the wind seldom blows from the east or southwest directions. Dust storms are common in the spring, when monthly average wind speeds reach $6.7 \mathrm{~m} / \mathrm{s}$ (15 miles an hour). During the spring and fall months, a diurnal cycle to the wind may be seen with northwest drainage winds for a time, and southerly winds by afternoon.

\section{Vegetation}

Temperature extremes and arid conditions of the high desert limit vegetation coverage. Sparse vegetation that occurs in Cactus Flat is predominantly range grasses and low shrubs typical of the Great Basin Desert flora (ERDA 1975; EG\&G 1979).

Vegetation is divided into two basic types at the site by elevation - salt desert shrub in the low areas and northern desert shrub in the higher elevations (USAF 1999, DRI 1991). Salt desert shrub is characteristic of poorly drained soils and is common along dry lakebeds. Specific plants in this group include shadescale (Atriplex confertilfolia), Russian thistle (Salsola kali), and sagebrush (Artemesia tridentata). Northern desert shrub, found in the Cactus Range, includes a variety of sagebrush, rabbitbrush (Chrysothamnus nauseosus), squirrel tail (Elymus longifolius), juniper (Juniperus), and Nevada bluegrass (Poa nevadensis). Joshua tree (Yucca brevifolia) and juniper grow in the transition zone at the base of the mountains.

\section{Wildlife}

The Nevada Wild Horse Range and other wild horse land-use areas compose a significant portion of the North Range with herds common in Cactus and Gold Flats, Kawich Valley, Goldfield Hills, and the Stonewall Mountains. Hundreds of wild horses (Equus caballus) graze freely throughout 
TTR and activities on-site have had little affect on the horse population or their grazing habits. The BLM routinely rounds up a portion of the herds for dispersal through the Horse Adoption Program.

Other mammals common to the area include pronghorn (Antilocapra americana), mule deer (Odocoileus hemionus), kit fox (Vulpes macrotis), bobcat (Zynx rufus), coyote (Canis latrans), and gray fox (Urocyon cinereoargenteus). To a lesser extent, bighorn sheep (Ovis canadensis), mountain lion (Felis concolor), and burros (Equus asinus) are also present (USAF 1999, DRI 1991).

In general, the NTTR land withdrawal has provided a positive effect on local plant and animal life. Since much of the withdrawal area is undisturbed by human activity, large habitat areas are protected from the affects of public use.

\subsection{CLEAN SLATE AND DOUBLE TRACK SITES}

In May and June 1963, Project Roller Coaster included a series of four nuclear weapons destruction tests that resulted in plutonium dispersal in the surrounding soils. Three of these tests were conducted within the boundaries of TTR; the fourth was conducted on the NTTR just west of TTR. The three Project Roller Coaster test sites at TTR are referred to as Clean Slates 1, 2, and 3 (Figure 1-2).
The fourth test site at NTTR is referred to as Double Tracks. In 1996, Double Tracks was closed after soil contamination was remediated to a level of less than or equal to 200 picocurie per gram $(\mathrm{pCi} / \mathrm{g}$ ) of transuranics.

Table 1-1 summarizes test information related to the four Project Roller Coaster sites. DOE/NNSA/NSO is responsible for the remediation of these and all other Environmental Restoration (ER) sites (see Chapter 3) at TTR. Sandia Corporation will continue to be responsible for environmental compliance at these sites.

The initial cleanup of each Clean Slate site was conducted shortly after each test. Test-related debris was bladed into a hole at test ground zero and backfilled. An initial fence was built around each test area where the soil contamination was set at approximately $1,000 \mu \mathrm{g} / \mathrm{m}^{2}$ of plutonium. The soil survey was conducted on $61-\mathrm{m}$ grids with a hand-held survey meter or field instrument for the detection of low-energy radiation (FIDLER). In 1973 , additional outer fences were set at $40 \mathrm{pCi} / \mathrm{g}$ of plutonium in soil also using the hand-held meter method. Soil sampling is conducted periodically at these sites and the areas are visually inspected twice a year to determine whether any fence repairs are required. Any horses that may wander inside the fenced areas are promptly relocated.

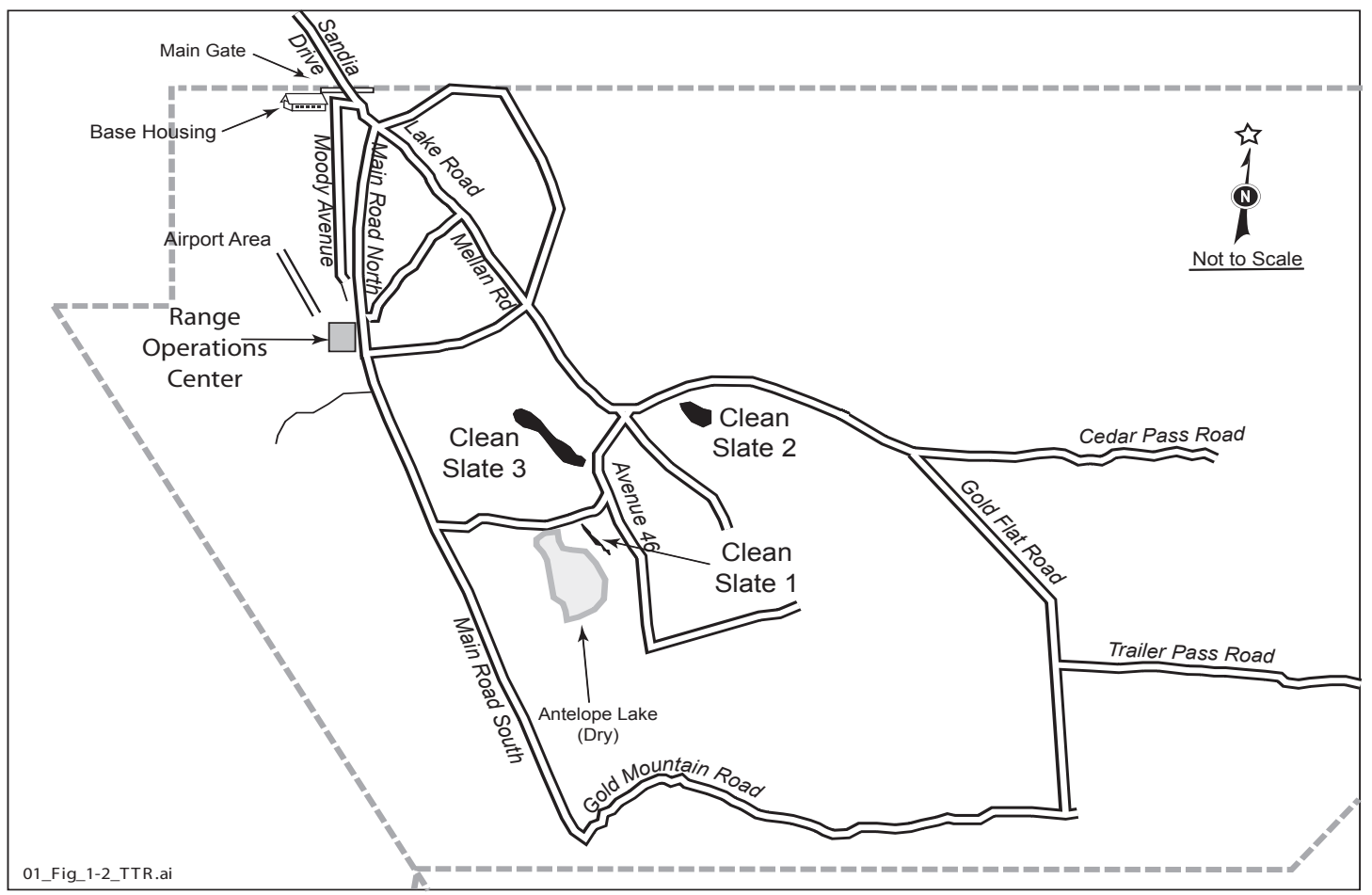

FIGURE 1-2. Location of Facilities Operated by SNL/NSO at TTR 
TABLE 1-1. Project Roller Coaster Test Information

\begin{tabular}{|c|c|c|c|}
\hline Test Name & Date of Test & Location & Status \\
\hline Clean Slate 1 & May 25, 1963 & TTR & Remediation phase \\
\hline Clean Slate 2 & May 31, 1963 & TTR & Remediation has not started \\
\hline Clean Slate 3 & June 9, 1963 & TTR & Closed \\
\hline Double Tracks & May 15, 1963 & $\begin{array}{c}\text { NTTR, North Range } \\
\text { (west of TTR) }\end{array}$ \\
NOTE: TTR = Tonopah Test Range \\
NTTR = Nevada Test and Training Range \\
Source : Sampling and Analysis Plan for Clean Slate 1, September 1996 (IT 1996)
\end{tabular}

In 1977 , an aerial radiological survey was performed by EG\&G, Inc. for the Nevada Applied Ecology Group (NAEG) (EG\&G 1995). The aerial radiological surveys were undertaken to supplement the FIDLER and previous soil sample measurements of transuranics. The objective was to determine the extent of surficial distribution of plutonium and other transuranic elements dispersed during the Project Roller Coaster tests. Radiation isopleths showing soil activity due to americium-241 (Am-241), plutonium-239 (Pu-239), and plutonium-240 (Pu240) were drawn for each area. The cumulative area of the diffuse sources, as determined by the aerial radiological survey, is 20 million $\mathrm{m}^{2}$ (approximately 4900 acres). The results of the survey found transuranic contamination outside the fenced area in the downwind direction (EG\&G 1995).

\section{Air Monitoring at ER sites}

Remediation activities were conducted at Clean Slate 1 in 1997. The Desert Research Institute (DRI) collected air monitoring data from several locations in the vicinity of Clean Slate 1 before, during, and after remediation activities. Although these data have been validated, they have only as of yet been presented to DOE/NSO in the form of a draft report (DRI 1997). Bechtel Nevada has two air monitoring stations available for use at TTR. DOE/NSO suspended air monitoring in April 2000 and will not resume until active remediation efforts at the Clean Slate sites begin again. Clean Slates 1,2, 3, and Double Tracks and a number of other sites at the Nevada Test Site are Corrective Action Units (CAUs) in the Soils Project, which has been suspended because of cleanup level issues. 
This page intentionally left blank. 


\section{chapter two}

\section{TTR COMPLIANCE}

\section{SUMMARY}

\section{In This Chapter ...}

Compliance Status with

Federal Regulations

2004 Audits

2004 Issues and Actions for

TTR

Environmental Permits

Occurrence Reporting

\section{Environmental Snapshot}

Environmental compliance permits for TTR include those for potable water supply, Resource Conservation and Recovery Act (RCRA), and specific air emission units, such as screening plants.
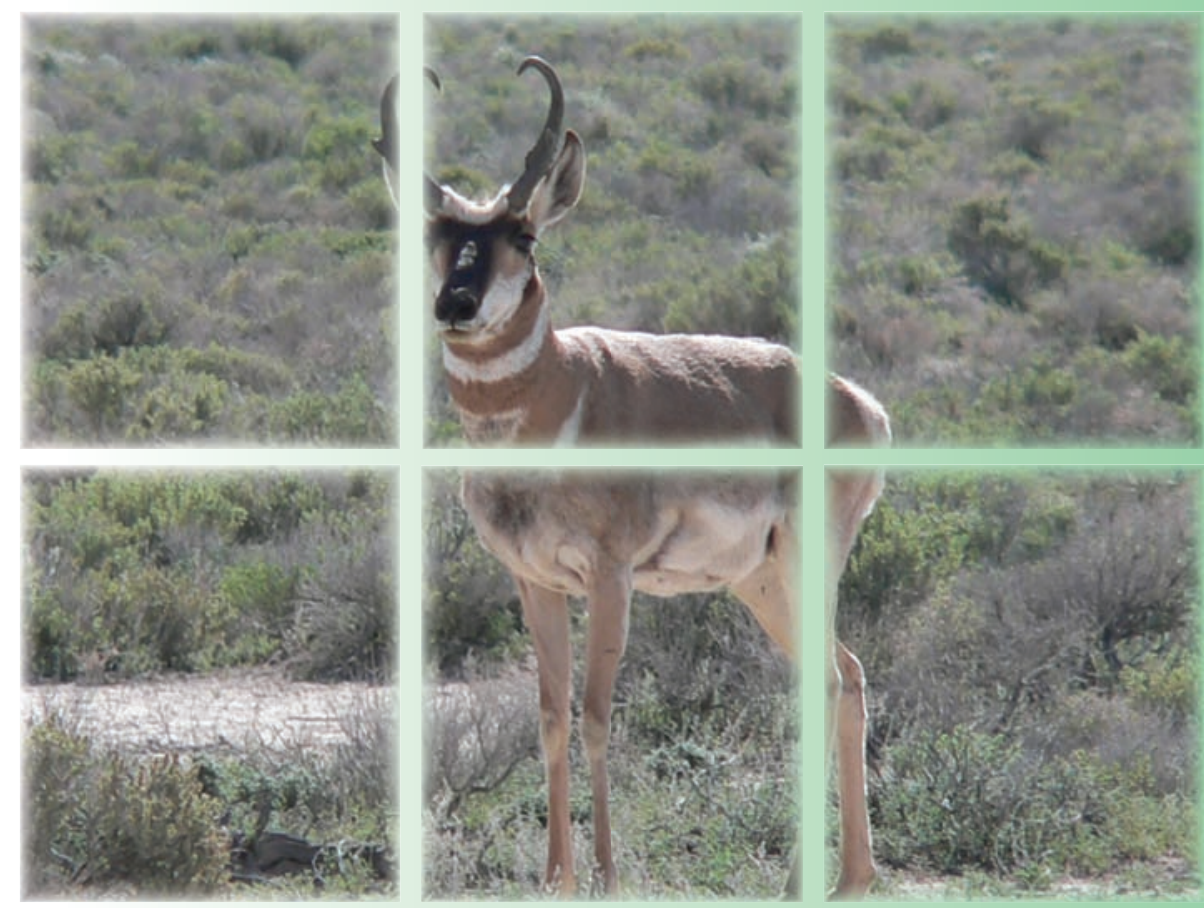
Sandia Corporation is responsible for Environment, Safety, and Health (ES\&H) compliance with federal environmental statutes, regulations, Executive Orders (EOs), and U.S. Department of Energy (DOE) Orders applicable to Tonopah Test Range (TTR).

This chapter discusses Sandia Corporation's responsibility and the status of ES\&H compliance. Environmental audit summaries, occurrence reporting, and environmental permit status for 2004 are also presented in this chapter.

The State of Nevada administers most environmental regulations applicable to TTR. Specific state regulations listed in Chapter 6 include regulations governing air quality, solid and hazardous waste management, wildlife, water quality, and radiation control. Radionuclide air emission regulations are administered directly by the U.S. Environmental Protection Agency (EPA).

\subsection{COMPLIANCE STATUS WITH FEDERAL REGULATIONS}

This section summarizes DOE and Sandia Corporation's compliance status with major environmental regulations, statutes, EOs, and DOE Orders that pertain to the environment.

Major federal laws applicable to environmental compliance at TTR are presented on page 2-3 (see shaded box).

\subsubsection{Comprehensive Environmental Response, Compensation, and Liability Act (CERCLA)}

CERCLA defines assessment activities and reporting requirements for inactive waste sites at federal facilities. As required by CERCLA, a Preliminary Assessment (PA) was submitted in 1988 for all facilities listed on the federal agency hazardous waste compliance docket. Sites with significant contamination were put on the National Priorities List (NPL) for cleanup (EPA 2005). There are no NPL or "Superfund" sites located at TTR.

Additional CERCLA requirements are given in the Superfund Amendments and Reauthorization Act (SARA) Title III for reportable quantity (RQ) releases and chemical inventory reporting. Sandia
Corporation at TTR was in full compliance with CERCLA, SARA, and RQ in 2004. Table 2-1 lists SARA Title III reporting requirements.

\subsubsection{Emergency Planning and Community Right-to-Know Act (EPCRA)}

SARA Title III (also known as EPCRA) requires the submittal of a Toxic Release Inventory (TRI) report for chemical releases over a given threshold quantity (TQ). The release reporting limit for lead is $100 \mathrm{lbs}$. The TTR Firing Range released approximately 1,790 lbs of non-recovered lead in 2004. This information will be reported in the Reporting Year (RY) 2004 TRI Report.

\subsubsection{Resource Conservation and Recovery Act (RCRA)}

Under the RCRA Hazardous Waste Permit Program (40 CFR 270), TTR is permitted as a "small quantity generator." Under this designation, hazardous waste can only be stored on-site for 180 days before it must be shipped off-site for treatment and disposal at an EPA-permitted facility. At TTR, hazardous waste shipments are scheduled to occur at least two to three times a year.

Sanitary solid waste, which is also regulated under RCRA, is disposed of at landfills on-site. There is one Class II sanitary landfill in operation at TTR operated by the U.S. Air Force (USAF) Operations and Maintenance contractor. The landfill is used cooperatively by all organizations at TTR.

Underground Storage Tanks (USTS) and Aboveground Storage Tanks (ASTs) - RCRA, Subchapter I (40 CFR 280) sets forth requirements for USTs that contain hazardous materials or petroleum products. The last five USTs (two diesel tanks and two gasoline tanks were removed from Area 3 at the site of a former gas station and one diesel tank was removed from Area 9 that had supplied generator fuel) were removed in August 1995. There are no ASTs requiring registration with the State of Nevada at TTR.

\subsubsection{Federal Facility Compliance Act (FFCA)}

The FFCA amendments to RCRA specifically address Land Disposal Restriction (LDR) requirements for the treatment of mixed waste (MW) at federal 


\section{Major Environmental Regulations \& Statutes Applicable to TTR}

\section{Clean Air Act (CAA) and CAA Amendments (CAAA)}

Provides standards to protect the nation's air quality http://www.epa.gov/oar/oaq caa.html

\section{Clean Water Act (CWA)}

Provides general water quality standards to protect the nation's water sources and byways

http://www.epa.gov/region5/watercwa.htm

\section{Comprehensive Environmental Response, Compensation, and Liability Act (CERCLA)}

Provides federal funding for cleanup of inactive waste sites on the National Priorities List (NPL) and mandates requirements for reportable releases of hazardous substances $\mathrm{http} / / \mathrm{www} . \mathrm{epa} . \mathrm{gov} / \mathrm{region} 5 / \mathrm{defs} / \mathrm{html} / \mathrm{cercla} . \mathrm{htm}$

\section{Cultural resources acts}

Includes various acts that protect archeological, historical, religious sites, and resources

http://water.usgs.gov/eap/env_guide/cultural.html

\section{Endangered Species Act (ESA)}

Provides special protection status for federally-listed endangered or threatened species http://www.epa.gov/region5/defs/html/esa.htm

\section{Executive Orders (EOs)}

Several EOs provide specific protection for wetlands, floodplains, environmental justice in minority and low-income populations, and greening the government through leadership in environmental management

http://www.archives.gov/federal_register/executive_orders/disposition_tables.html

\section{Federal Facility Compliance Act (FFCA)}

Directs federal agencies regarding environmental compliance http://tis.eh.doe.gov/oepa/laws/ffca.html

\section{Federal Insecticide, Fungicide, and Rodenticide Act (FIFRA)}

Controls the distribution and use of various pesticides http://www.epa.gov/region5/defs $/ \mathrm{html} / \mathrm{fifra} . \mathrm{htm}$

\section{Migratory Bird Treaty Act (MBTA) of 1918}

Prevents the taking, killing, possession, transportation and importation of migratory birds, their eggs, parts, and nests http://tis.eh.doe.gov/oepa/laws/mbta.html

\section{National Emission Standards for Hazardous Air Pollutants (NESHAP)}

Specifies standards for radionuclide air emissions and other hazardous air releases under the CAA http://www.epa.gov/radiation/neshaps/

\section{National Environmental Policy Act (NEPA)}

Requires federal agencies to review all proposed activities so as to include environmental aspects in agency decision-making http://tis.eh.doe.gov/NEPA/

\section{Resource Conservation and Recovery Act (RCRA)}

Mandates the management of solid and hazardous waste and certain materials stored in underground storage tanks (USTs) http://www.epa.gov/region5/defs/html/rcra.htm

\section{Safe Drinking Water Act (SDWA)}

Provides specific standards used for drinking water sources $\mathrm{http}: / /$ www.epa.gov/safewater/sdwa/sdwa.html

\section{Superfund Amendments and Reauthorization Act (SARA)}

SARA,Title III, also known as the Emergency Planning and Community-Right-to-Know Act (EPCRA), mandates comunication standards for hazardous materials over a threshold amount that are stored or used in a community http://www.epa.gov/region5/defs/html/sara.htm

\section{Toxic Substance Control Act (TSCA)}

Specifies rules for the manufacture, distribution, and disposal of specific toxic materials such as asbestos and polychlorinated biphenyls (PCBs) http://www.epa.gov/compliance/civil/tsca/index.html 
TABLE 2-1. 2004 SARA Title III (or EPCRA) Reporting Requirements Applicable to TTR

\begin{tabular}{|c|c|c|c|c|}
\hline \multirow[t]{2}{*}{ Section } & \multirow{2}{*}{$\begin{array}{l}\text { SARA Title } \\
\quad \text { III } \\
\text { Section Title }\end{array}$} & \multicolumn{2}{|c|}{$\begin{array}{l}\text { Requires } \\
\text { Reporting? }\end{array}$} & \multirow[t]{2}{*}{ Description } \\
\hline & & Yes & No & \\
\hline $302-303$ & $\begin{array}{l}\text { Emergency } \\
\text { Planning }\end{array}$ & $\mathrm{X}$ & & $\begin{array}{l}\text { Sandia Corporation submits an annual report listing chemical } \\
\text { inventories above the reportable Threshold Planning Quantities } \\
\text { listed in } 40 \text { CFR Part } 355 \text { Appendix B, location of the chemicals } \\
\text { and emergency contacts. The report is prepared for the DOE/ } \\
\text { NNSA/SSO which distributes it to the required entities. }\end{array}$ \\
\hline 304 & $\begin{array}{l}\text { Emergency } \\
\text { Notification }\end{array}$ & & $X$ & $\begin{array}{l}\text { No RQ releases of an EHS, or as defined under CERCLA, oc- } \\
\text { curred in } 2004 .\end{array}$ \\
\hline 311-312 & $\begin{array}{l}\text { Hazardous } \\
\text { Chemical } \\
\text { Storage } \\
\text { Reporting } \\
\text { Requirements }\end{array}$ & $\mathrm{X}$ & & $\begin{array}{l}\text { There are two "Community Right-to-Know" reporting require- } \\
\text { ments: (a) SNL/NM completes the EPA Tier II forms for all } \\
\text { hazardous chemicals present at the facility at any one time in } \\
\text { amounts equal to or greater than } 10,000 \text { lbs and for all EHSs pres- } \\
\text { ent at the facility in an amount greater than or equal to } 500 \mathrm{lbs} \text { or } \\
\text { the Threshold Planning Quantity, whichever is lower; (b) TTR } \\
\text { provides MSDSs for each chemical entry on a Tier II form unless } \\
\text { it decides to comply with the EPA's alternative MSDS reporting, } \\
\text { which is detailed in } 40 \text { CFR Part } 370.21 \text {. }\end{array}$ \\
\hline 313 & $\begin{array}{l}\text { Toxic Chemi- } \\
\text { cal Release } \\
\text { Forms }\end{array}$ & $\mathrm{X}$ & & $\begin{array}{l}\text { EPCRA, Section 313, requires that facilities that use toxic chemi- } \\
\text { cals listed in SARA Tile III over a threshold value must submit a } \\
\text { TRI report. For RY 2004, a report was submitted for lead. }\end{array}$ \\
\hline
\end{tabular}

NOTE: MSDS = Material Safety Data Sheets (gives relevant chemical information)

$\begin{array}{ll}\text { TRI = Toxic Release Inventory } & \text { DOE = U.S. Department of Energy } \\ \text { SSO = Sandia Site Office } & \text { EPA = U.S. Environmental Protection Agency } \\ \text { NNSA = National Nuclear Security Administration } & \text { RY = reporting year } \\ \text { CIS = Chemical Inventory System } & \text { lbs = pounds } \\ \text { CERCLA = Comprehensive Environmental Response, Compensation, and Liability Act } \\ \text { EPCRA = Emergency Planning and Community Right-to-Know Act } \\ \text { SARA = Superfund Amendments and Reauthorization Act }\end{array}$

facilities. Since TTR does not generate MW and currently has no MW stored on-site, this statute is not applicable to Sandia Corporation's operations at TTR.

\subsubsection{Clean Air Act (CAA) and Clean Air Act Amendments (CAAA) of 1990}

CAA and CAAA of 1990 requirements are regulated by the State of Nevada air quality regulations. Air emissions from non-radionuclide sources, such as a screening plant and a portable screen, are permitted under a Class II Air Quality Permit. Sandia Corporation tracks emissions and pays a fee to the State of Nevada based on the total standard tons emitted. Sandia Corporation met all air quality permit conditions in 2004.

\section{National Emission Standards for Hazardous Air Pollutants (NESHAP) Compliance}

The EPA retains compliance authority for all radionuclide air releases, which are regulated by NESHAP and implemented under 40 CFR 61,
Subpart H. The Clean Slate sites, as discussed in Chapter 1, have been the only source of radionuclide air emissions at TTR. Continuous air monitoring was conducted from February 22, 1996 to February 25, 1997 (SNL 1997). The TTR Airport was determined to be the location of the maximally exposed individual (MEI). The result of 0.024 millirems per year (mrem/yr) was below the threshold of $0.1 \mathrm{mrem} / \mathrm{yr}$ for which continuous air monitoring would be required and approximately 400 times less than the EPA standard of $10 \mathrm{mrem} / \mathrm{yr}$. The NESHAP Annual Report for 2004 and Chapter 4 of this report discuss these monitoring results (SNL 2005).

\subsubsection{Clean Water Act (CWA)}

Wastewater effluents and potable water supplies are regulated under the CWA and State of Nevada water pollution and sanitary waste systems regulations. The State of Nevada, Bureau of Health Protection Services and the Nevada Department of Environmental Protection (NDEP) administer 
regulations relevant to wastewater discharges. At TTR, wastewater is discharged to the sewer system connected to the USAF sewage lagoon and to six septic tank systems.

There were no excursions or other permit violations in 2004 with respect to wastewater discharges.

\section{Storm Water}

The issuance of a National Pollutant Discharge Elimination System (NPDES) storm water permit is generally based on whether or not storm water runoff is discharged to "Waters of the U.S." This definition includes rivers, lakes, streams, and swamps, as well as channels and arroyos that lead to waters that are currently used, have been used in the past, or may be susceptible for use in interstate or foreign commerce. The TTR site is primarily a closed basin with runoff evaporating or infiltrating to the ground. The USAF has permitted its airfield and Area 10 for storm water runoff and have cognizance over all storm water issues at the site. Currently, Sandia Corporation does not conduct any activities at TTR that require storm water permitting or monitoring.

\subsubsection{Safe Drinking Water Act (SDWA)}

Sandia Corporation meets standards for drinking water as defined in the SDWA and State of Nevada public water supply and public water systems regulations. Well 6 provides all drinking water for Sandia Corporation's operations at TTR and is operated under a permit issued by the State of Nevada. Chapter 4 of this report discusses monitoring activities.

\subsubsection{Toxic Substances Control Act (TSCA)}

Compliance with TSCA at TTR primarily concerns the management of asbestos and polychlorinated biphenyls (PCBs). As defined by the TSCA, any material with greater than or equal to 500 parts per million (ppm) is considered a "PCB"; materials with greater than or equal to $50 \mathrm{ppm}$, but less than 500 ppm are considered as "PCB-contaminated." In 1993, sampling was performed on TTR transformers to determine if PCBs were present in the soil (IT 1993). All samples contained less than $50 \mathrm{ppm}$ of PCBs.

Decontamination and demolition (D\&D) operations conducted at TTR during 2004 generated $8 \mathrm{yd}^{3}$ of asbestos containing material (ACM) waste.

\subsubsection{Federal Insecticide, Fungicide, and Rodenticide Act (FIFRA)}

Chemical pesticides used at TTR include herbicides, rodenticides, and insecticides, as required. All chemicals used are EPA-approved and applied in accordance with applicable label guidelines and regulations. Sandia Corporation retains records of the quantities and types of pesticides that are used as well as Material Safety Data Sheets (MSDSs) for each pesticide. There were no violations of the FIFRA in 2004.

\subsubsection{National Environmental Policy Act (NEPA)}

NEPA requires federal agencies and private entities that perform federally-sponsored projects to include environmental aspects in early project planning and decision-making. A major intent of the law is to ensure that federal agencies are aware of the potential environmental impacts associated with their operations and include this information in early project planning and decision making. NEPA mandates that an agency's decision process be open for public review. Additionally, if a proposed action is determined to have environmentally "significant" impacts, the agency must prepare an environmental assessment (EA) or an environmental impact statement (EIS) before an irretrievable commitment of resources or funding occurs. Although a major objective of NEPA is to preserve the environment for future generations, the law does not require an agency to select the proposed action alternative with the least environmental impacts.

NEPA activities are discussed in Section 3.4.

\subsubsection{Endangered Species Act (ESA)}

The ESA applies to both private individuals and federal agencies. Federal agencies must ensure that any action authorized, funded, or carried out by them will not jeopardize the continued existence of a threatened or endangered species, or result in adverse modifications of its habitat. The ESA is addressed under the NEPA Program and Ecology Program. If potentially significant impacts to sensitive species or habitats are found as a result of the proposed action, an EA or an EIS must be prepared. 
Table 2-2 lists all federal and state protected species occurring within Nye County; therefore, having the potential to occur at TTR.

\subsubsection{Migratory Bird Treaty Act (MBTA)}

The MBTA of 1918 implemented the 1916 Convention for the protection of migratory birds. The original statute implemented the agreement between the United States (U.S.) and Great Britain (for Canada) and later amendments implemented treaties between the U.S. and Mexico, the U.S. and Japan, and the U.S. and Russia. The MBTA prevents the taking, killing, possession, transportation and importation of migratory birds, their eggs, parts, and nests. Federal institutions are not exempt from the MBTA. New guidance is being developed by the U.S. Fish and Wildlife Service to assist federal institutions in interpreting this Act. At Sandia Corporation's TTR, the MBTA is coordinated with NEPA compliance reviews and the Ecology Program.

\subsubsection{Cultural Resources Acts}

Federal cultural resources management responsibilities are applicable to activities at TTR. These include but are not limited to compliance with the following laws and their associated regulations:

- National Historic Preservation Act (NHPA)

- Archaeological Resources Protection Act (ARPA)

- American Indian Religious Freedom Act (AIRFA)

DOE/National Nuclear Security Administration (NNSA) Sandia Site Office (SSO) is responsible for determining the level of applicability of cultural resources requirements. In 2004, Sandia Corporation's operations did not impact any known cultural resources sites at TTR.

\section{Historical Building Assessment}

In 2004, DOE/NNSA/SSO initiated a consultation with the Nevada State Historic Preservation Office (SHPO) on 212 buildings at TTR. The SHPO did not concur with the DOE determination of eligibility for the 212 buildings. At the SHPO's request, Sandia Corporation contracted with an architectural historian to evaluate the TTR buildings under National Register Criterion C. A revised report on the buildings at TTR will be submitted to the Nevada SHPO during 2005.

A consultation with the Nevada SHPO for rebuilding the TTR power system was initiated in 2004. A cultural resource inventory report was completed following an intensive archeological and historic inventory of the proposed project area. No historic properties were found within the proposed project area. As a result, in January 2005, the SHPO concurred with the DOE/NNSA/SSO determination that no historic properties would be affected by the proposed undertaking.

\subsubsection{Environmental Compliance EOs}

EO 11988, Floodplain Management, as amended, and EO 11990, Protection of Wetlands, as amended, require evaluation of the potential effects of actions taken in these environmentally sensitive areas. There are no floodplains or significant wetlands at TTR; however, some very limited wetlands exist in the vicinity of several springs. These provide an important source of drinking water for wildlife in the area. Sandia Corporation complies with all applicable mandates stated in these EOs.

EO 12898, Federal Actions to Address Environmental Justice in Minority Populations and Low-Income Populations, as amended, requires that to the greatest extent practicable and permitted by law, and consistent with the principles set forth in the Report on the National Performance Review (Gore 1993), each federal agency shall make achieving environmental justice part of its mission by identifying and addressing, as appropriate, disproportionately high and adverse human health or environmental effects of its programs, policies, and activities on minority populations and lowincome populations in the United States and its territories and possessions. Sandia Corporation must include in the assessment of its operations any disproportionate impacts on minority or lowincome populations within the area of influence of the Laboratories' operations.

EO 13148, Greening the Government Through Leadership in Environmental Management, requires federal agencies to ensure that "all necessary actions are taken to integrate environmental accountability into agency day-to-day decision-making and longterm planning processes, across all agency missions, activities, and functions." Among the primary 
TABLE 2-2. Protected Species Potentially Occurring in Nye County, Nevada

\begin{tabular}{|c|c|c|c|}
\hline $\begin{array}{l}\text { Common Name } \\
\text { PLANTS }\end{array}$ & Scientific Name & Federal Status & $\begin{array}{c}\text { State of Nevada } \\
\text { Status }\end{array}$ \\
\hline Sodaville Milkvetch & Astragalus lentiginosus var. sesquimetralis & --- & State Protected \\
\hline Halfring Milkvetch & Astragalus mohavensis var hemigyrus & SOC & State Protected \\
\hline Ash Meadows Milkvetch & Astragalus phoenix & Threatened & State Protected \\
\hline Armored Hedgehog Cactus & Echinocereus engelmannii var. armatus & --- & State Protected \\
\hline Ash Meadows Sunray & Enceliopsis nudicaulis var. corrugata & Threatened & State Protected \\
\hline Mojave Barrel Cactus & Ferocactus cylindraceus var. lecontei & & State Protected \\
\hline Sunnyside Green Gentian & Frasera gypsicola & SOC & State Protected \\
\hline Ash Meadows Gumplant & Grindelia fraxinopratensis & Threatened & State Protected \\
\hline Ash Meadows Mousetails & Ivesia kingii var. eremica & Threatened & State Protected \\
\hline Ash Meadows Blazingstar & Mentzelia leucophylla & Threatened & State Protected \\
\hline Amargosa Niterwort & Nitrophila mohavensis & Endangered & State Protected \\
\hline Sand Cholla & Opuntia pulchella & --- & State Protected \\
\hline Williams Combleaf & Polyctenium williamsiae & --- & State Protected \\
\hline Blaine Pincushion & Sclerocactus blainei & SOC & State Protected \\
\hline Tonopah Pincushion & Sclerocactus nyensis & --- & State Protected \\
\hline Hermit Cactus & Sclerocactus polyancistrus & --- & State Protected \\
\hline \multicolumn{4}{|l|}{ INSECTS } \\
\hline Ash Meadows Naucorid & Ambrysus amargosus & Threatened & --- \\
\hline \multicolumn{4}{|l|}{ FISH } \\
\hline White River Desert Sucker & Catostomus clarki intermedius & SOC & State Protected \\
\hline Moorman White River Springfish & Crenichthys baileyi thermophilus & SOC & State Protected \\
\hline Railroad Valley Springfish & Crenichthys nevadae & Threatened & State Protected \\
\hline Devils Hole Pupfish & Cyprinodon diabolis & Endangered & State Protected \\
\hline Ash Meadows Amargosa Pupfish & Cyprinodon nevadensis mionectes & Endangered & State Protected \\
\hline Warm Springs Amargosa Pupfish & Cyprinodon nevadensis pectoralis & Endangered & State Protected \\
\hline Pahrump Poolfish & Empetrichthys latos latos & Endangered & State Protected \\
\hline White River Spinedace & Lepidomeda albivallis & Endangered & State Protected \\
\hline Moapa Dace & Moapa coriacea & Endangered & State Protected \\
\hline Lahontan Cutthroat Trout & Oncorhynchus clarki henshawi & Threatened & State Protected \\
\hline Big Smoky Valley Speckled Dace & Rhinichthys osculus lariversi & & State Protected \\
\hline Ash Meadows Speckled Dace & Rhinichthys osculus nevadensis & Endangered & State Protected \\
\hline Big Smokey Valley Tui Chub & Siphateles bicolor ssp. 8 & SOC & State Protected \\
\hline Hot Creek Valley Tui Chub & Siphateles bicolor ssp. 5 & SOC & State Protected \\
\hline Little Fish Lake Valley Tui Chub & Siphateles bicolor ssp. 4 & & State Protected \\
\hline Railroad Valley Tui Chub & Siphateles bicolor ssp. 7 & $\mathrm{SOC}$ & State Protected \\
\hline \multicolumn{4}{|l|}{ AMPHIBIANS } \\
\hline Amargosa Toad & Bufo nelsoni & --- & State Protected \\
\hline Columbia Spotted Frog & Rana luteiventris pop 3 & Candidate & --- \\
\hline \multicolumn{4}{|l|}{ REPTILES } \\
\hline Banded Gila Monster & Heloderma suspectum cinctum & SOC & State Protected \\
\hline $\begin{array}{l}\text { Desert Tortoise (Mojave Desert } \\
\text { pop.) }\end{array}$ & Gopherus agassizii & Threatened & State Protected \\
\hline \multicolumn{4}{|l|}{ MAMMALS } \\
\hline Spotted Bat & Euderma maculatum & SOC & State Protected \\
\hline Pygmy Rabbit & Brachylagus idahoensis & SOC & State Protected \\
\hline American Pika & Ochotona princeps & --- & State Protected \\
\hline Kit Fox & Vulpes macrotis & --- & State Protected \\
\hline BIRDS & & & \\
\hline Northern Goshawk & Accipiter gentilis & SOC & State Protected \\
\hline Golden Eagle & Aquila chrysaetos & --- & State Protected \\
\hline Long-eared Owl & Asio otus & --- & State Protected \\
\hline Western Burrowing Owl & Athene cunicularia hypugaea & SOC & State Protected \\
\hline Juniper Titmouse & Baeolophus griseus & --- & State Protected \\
\hline Ferruginous Hawk & Buteo regalis & SOC & State Protected \\
\hline Swainson's Hawk & Buteo swainsoni & --- & State Protected \\
\hline Sage Grouse & Centrocercus urophasianus & --- & State Protected \\
\hline Western Snowy Plover & Charadrius alexandrinus nivosus & Threatened & State Protected \\
\hline Mountain Plover & Charadrius montanus & Proposed Threatened & State Protected \\
\hline Black Tern & Chlidonias niger & SOC & State Protected \\
\hline Western Yellow-billed Cuckoo & Coccyzus americanus occidentalis & Candidate & State Protected \\
\hline Yellow Warbler & Dendroica petechia & --- & State Protected \\
\hline Southwestern Willow Flycatcher & Empidonax traillii extimus & Endangered & State Protected \\
\hline Prarie Falcon & Falco mexicanus & --- & State Protected \\
\hline Common Yellowthroat & Geothlypis trichas & --- & State Protected \\
\hline Greater Sandhill Crane & Grus canadensis tabida & --- & State Protected \\
\hline Pinyon Jay & Gymnorhinus cyanocephalus & --- & State Protected \\
\hline Yellow-breasted Chat & Icteria virens & --- & State Protected \\
\hline Western Least Bittern & Ixobrychus exilis hesperis & SOC & State Protected \\
\hline Loggerhead Shrike & Lanius ludovicianus & SOC & State Protected \\
\hline Lewis' Woodpecker & Melanerpes lewis & --- & State Protected \\
\hline Long-billed Curlew & Numenius americanus & --- & State Protected \\
\hline Macgillivray's Warbler & Oporornis tolmiei & --- & State Protected \\
\hline Mountain Quail & Oreortyx pictus & --- & State Protected \\
\hline Flammulated Owl & Otus flammeolus & --- & State Protected \\
\hline Osprey & Pandion haliaetus & --- & State Protected \\
\hline Phainopepla & Phainopepla nitens & $\overline{---}$ & State Protected \\
\hline White-faced Ibis & Plegadis chihi & SOC & State Protected \\
\hline Vesper Sparrow & Pooecetes gramineus & --- & State Protected \\
\hline Yuma Clapper Rail & Rallus longirostris yumanensis & Endangered & State Protected \\
\hline Red-naped Sapsucker & Sphyrapicus nuchalis & --- & State Protected \\
\hline Crissal Thrasher & Toxostoma crissale & --- & State Protected \\
\hline Orange-crowned Warbler & Vermivora celata & --- & State Protected \\
\hline Lucy’s Warbler & Vermivora luciae & --- & State Protected \\
\hline Grey vireo & Vireo vicinior & --- & State Protected \\
\hline
\end{tabular}


agency goals is support to the development and implementation of environmental compliance audit programs and policies "that emphasize pollution prevention as a means to both achieve and maintain environmental compliance." Sandia Corporation is working under guidance from DOE/NNSA/SSO toward compliance with this EO.

\subsection{AUDITS}

Table 2-3 lists audits conducted in 2004, including an assessment made by Sandia Corporation.

\subsection{ISSUES AND ACTIONS FOR TTR}

Sandia Corporation's ongoing self-assessments continue to look for potential compliance issues and subsequent follow-up actions.

Federal Facility Agreement and Consent Order (FFACO) Compliance for ER Activities

An ongoing action started in 1996 is the FFACO with the State of Nevada. This agreement was implemented in May 1996 between the State of Nevada, DOE, and the U.S. Department of Defense (DoD) (DoD/DOE/State of NV 1996). All DOE cleanup activities in the State of Nevada must be conducted in conformance with the requirements of this agreement. The FFACO is an enforceable agreement with stipulated penalties for violations. The ER sites for which DOE has assumed responsibility, and which are subject to the FFACO:

- NTS,

- Areas within TTR,

- Areas within the NTTR,

- Central Nevada Test Area, and

- Project Shoal Area (east of Carson City in Churchill County).
A summary of DOE/NNSA's ER sites in Nevada can be found in the FFACO report (DOD/DOE/State of NV 1996). The list of sites has been modified for consistency with NDEP requirements and grouped into Corrective Action Units (CAUs), which are listed by Corrective Action Site (CAS) numbers. Each CAU is listed in the FFACO under Appendices II (inactive CAUs) and III (active CAUs) and are updated every six months. A listing of ER sites located at TTR is shown in Chapter 3, Table 3-1.

\subsection{ENVIRONMENTAL PERMITS}

Environmental compliance permits for TTR include those for potable water supply, RCRA, and specific air emission units, such as screening plants. The permit application and registration of Sandia Corporation activities at TTR are issued directly by the State of Nevada to either DOE/NNSA, Nevada Site Office (NSO) or DOE/NNSA/SSO and administered by Westinghouse Government Service on behalf of Sandia Corporation. Sandia Corporation and Westinghouse Government Service ensure that all permit conditions are met. Table 2-4 lists all permits and registrations in effect in 2004.

\subsection{OCCURRENCE REPORTING}

There were no reportable occurrences in 2004. 
TABLE 2-3. Summary of Environmental Audits Performed at TTR in 2004

\begin{tabular}{|l|l|l|l|}
\hline \multicolumn{1}{|c|}{ Type/Subject } & \multicolumn{1}{|c|}{ Date } & \multicolumn{1}{c|}{ Audit Organization } & \multicolumn{1}{c|}{ Findings Summary } \\
\hline $\begin{array}{l}\text { Spill Prevention } \\
\text { Counter Control } \\
\text { Measures }\end{array}$ & April 2004 & NNSA/SSO & $\begin{array}{l}\text { One Finding (Plan not up to date) } \\
\text { Seven Observations and Five Note- } \\
\text { worthy comments. }\end{array}$ \\
\hline $\begin{array}{l}\text { ES\&H Self-Assessment } \\
\text { of the Tonopah Test } \\
\text { Range }\end{array}$ & May 2004 & SNL Center 15000 & $\begin{array}{l}\text { Numerous Observations mostly } \\
\text { related to training. }\end{array}$ \\
\hline Air Quality & June 2004 & State of Nevada & There were no findings. \\
\hline $\begin{array}{l}\text { Quality Assessment } \\
\text { of the Tonopah Test } \\
\text { Range }\end{array}$ & May - July 2004 & NNSA/SSO & $\begin{array}{l}\text { Numerous findings mostly related to } \\
\text { Emergency Management. }\end{array}$ \\
\hline
\end{tabular}

NOTE: NNSA/SSO = National Nuclear Security Administration, Sandia Site Office

TTR $=$ Tonopah Test Range

ES\&H = Environment, Safety, and Health

TABLE 2-4. 2004 Summary of Permit Ownership at TTR

\begin{tabular}{|c|c|c|c|c|}
\hline Permit Type and Location & $\begin{array}{l}\text { Permit } \\
\text { Number }\end{array}$ & $\begin{array}{l}\text { Tssue } \\
\text { Date }\end{array}$ & $\begin{array}{c}\text { Expiration } \\
\text { Date }\end{array}$ & Comments \\
\hline \multicolumn{5}{|l|}{ Air Quality Permits } \\
\hline $\begin{array}{l}\text { Class II Air Quality } \\
\text { Operation Permit }\end{array}$ & AP9611-0680.01 & $\begin{array}{l}\text { July 23, } \\
2001\end{array}$ & July 23, 2006 & $\begin{array}{l}\text { 1- 3'x 5' Screening Plant } \\
\text { 1- 7'x 7' Portable Screen } \\
\text { Non-Permit Equipment List } \\
\text { Generators (53 emission units) } \\
\text { Boilers ( } 7 \text { emission units) } \\
\text { Maintenance Activities } \\
\text { (5 emission units) } \\
\text { Propane Storage Tanks } \\
\text { (23 emission units) } \\
\text { Surface Area Disturbance } \\
\text { (> } 5 \text { acres) }\end{array}$ \\
\hline \multicolumn{5}{|l|}{ RCRA - Hazardous Waste } \\
\hline Hazardous Waste Generator & NV1890011991 & $\begin{array}{l}\text { January 7, } \\
1993\end{array}$ & Indefinite & State of Nevada \\
\hline \multicolumn{5}{|c|}{ Production Well (Drinking Water) } \\
\hline Well 6 Production Well & NY-3014-12NC & $\begin{array}{l}\text { September } \\
2003\end{array}$ & $\begin{array}{l}\text { September } \\
2004^{*}\end{array}$ & State of Nevada \\
\hline
\end{tabular}

NOTE: * The State of Nevada Bureau of Health Protection Services renews the permit for Well 6 (NY-3014-12NC) annually.

TTR $=$ Tonopah Test Range

RCRA = Resource Conservation and Recovery Act

"Emission units" are sources such as generators and boilers. 
This page intentionally left blank. 


\section{chapter three}

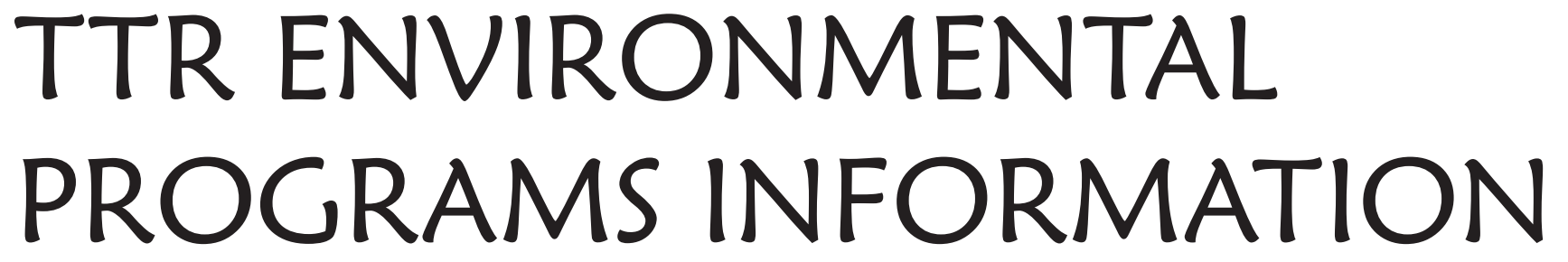

\section{$\underline{\text { In This Chapter ... }}$}

ER Project Activities

Waste Management Programs

Spill Prevention Control and

Countermeasures Plan

National Environmental Policy

Act

Environmental Monitoring

Performed by Outside Agencies

Summary of Release Reporting

Environmental Snapshot

In 2004, investigation

activities at Environmental

Restoration sites generated

a total of $255 \mathrm{~kg}(495 \mathrm{lb})$

of waste including $200 \mathrm{~kg}$

(440 lb) of non-RCRA waste and $25 \mathrm{~kg}(55 \mathrm{lb})$ of RCRA hazardous waste.
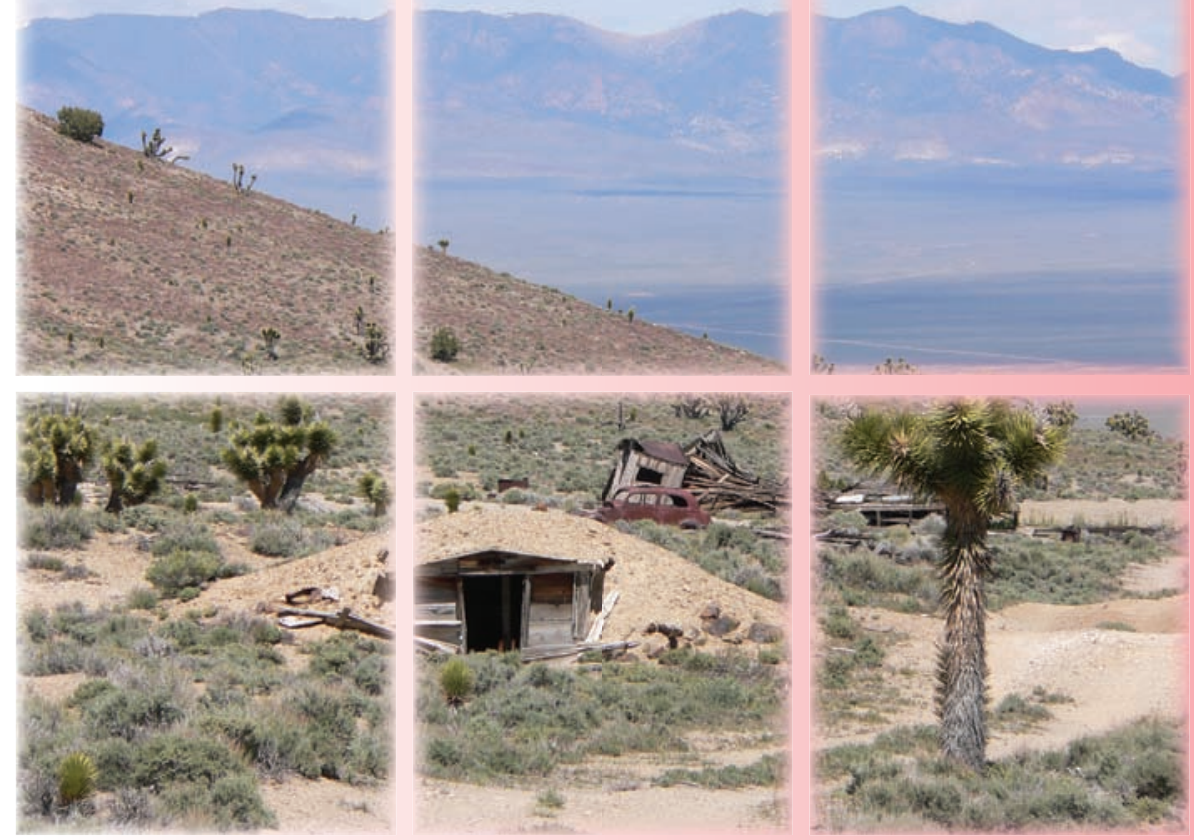

View of Mountain Range at Tonopah Test Range 
The Environmental Restoration (ER) Project, the Waste Management Program, and the National Environmental Policy Act (NEPA) Program are some of the programs and activities Sandia Corporation's Tonopah Test Range (TTR) utilizes to meet compliance with various state and federal regulations, Executive Orders (EOs), and U.S. Department of Energy (DOE) Orders. Terrestrial surveillance, drinking water, wastewater, and air quality programs are discussed in Chapter 4 of this report.

\subsection{ER PROJECT ACTIVITIES}

The ER Project at TTR began in 1980 to address contamination resulting primarily from nuclear weapons testing and related support activities. In late 1992 and early 1993, an agreement was reached between DOE Headquarters (HQ), the DOE/ National Nuclear Security Administration (NNSA) Service Center and the DOE, Nevada Site Office (NSO) regarding the management of ER activities at TTR. The decision was made to designate the responsibility of all ER sites to DOE/NSO.

Since 1996, cleanup activities for sites located in the State of Nevada have been regulated by the Federal Facility Agreement and Consent Order (FFACO) (DoD/DOE/State of NV 1996). The FFACO was negotiated between DOE/NSO, the Nevada Division of Environmental Protection (NDEP), and the U.S. Department of Defense (DoD). The FFACO took effect on May 10, 1996 and accomplished the following:

- Established a framework for identifying Corrective Action Sites (CASs),

- Grouped CASs into Corrective Action Units (CAUs),

- $\quad$ Prioritized CAUs, and

- Implemented corrective action activities.

The FFACO is also discussed in Section 2-3. CAUs located at TTR are addressed by two ER Division Projects:

(1) Industrial Sites Project - Past sites used to support nuclear testing activities, and

(2) Soil Sites Project - Areas where tests resulted in extensive surface and/or shallow subsurface contamination.
ER site contamination includes radiological (e.g., depleted uranium [DU] and plutonium) and nonradiological constituents (e.g., artillery, solvents, septic sludges, and heavy metals).

\section{CAS Identification}

The initial identification, description, and listing of CASs at TTR were derived from the Preliminary Assessment (PA) and the Federal Facility Preliminary Assessment Review (E\&E 1989). In 1993, the potential TTR CASs identified in the PA were subdivided into four "Soil Sites CAUs" and 43 "Industrial Sites CAUs." Twelve additional potential CASs not included in the PA were also identified. These CASs were identified through:

- ER sites inventory process,

- Ordnance removal activities,

- Geophysical surveys,

- Former worker interviews,

- Archive reviews,

- Site visits, and

- Aerial radiological and multispectral surveys

(1993 to 1996).

The remediation activities at the Clean Slate and Double Tracks sites (Project Roller Coaster) are discussed in Chapter 1. These sites are listed under Soil Sites CAUs/CASs in Table 3-1 as CAU-411, $-412,-413$, and -414 .

Table 3-1 summarizes the existing Industrial and Soil Sites CAUs and CASs at TTR. The ER activities planned for these CASs range from "no activities currently planned" to "NDEP-approved closure." The CAS information presented in Table 3-1 is contained in Appendices II, III, and IV of the FFACO (DoD/DOE/State of NV 1996).

\section{ER Activities}

In 2004, ER activities were focused on investigation and delineation of corrective action sites in preparation for cleanup activities. Investigation activities at ER sites generated a total of $255 \mathrm{~kg}$ (495 lb) of waste including $200 \mathrm{~kg}$ (440 lb) of nonResource Conservation and Recovery Act (RCRA) waste and $25 \mathrm{~kg}(55 \mathrm{lb})$ of RCRA hazardous waste. RCRA waste consisted of spent field-testing kits and associated debris. All RCRA waste was transported to the Nevada Test Site (NTS) for processing and disposal at a permitted treatment, storage, and disposal (TSD) facility. No low-level waste (LLW) 
TABLE 3-1. DOE/NNSA/NSO ER Project TTR CAUs and CASs Calendar Year (CY) 2004 Status

\begin{tabular}{|c|c|c|}
\hline \multicolumn{3}{|c|}{ Industrial Sites CAUs/CASs } \\
\hline CAS Number & CAS Description & General Location \\
\hline \multicolumn{3}{|c|}{$\begin{array}{l}\text { CAU-400 - Closed } \\
\text { Bomblet Pit and Five Points Landfill, TTR }\end{array}$} \\
\hline TA-19-001-05PT & Ordnance Disposal Pit & Five Points Intersection \\
\hline TA-55-001-TAB2 & Ordnance Disposal Pit & Bunker 2 Road \\
\hline \multicolumn{3}{|c|}{$\begin{array}{l}\text { CAU-401 - Closed } \\
\text { Area } 3 \text { Gas Station UST Site, TTR }\end{array}$} \\
\hline 03-02-003-0357 & UST, Gas & First Gas Station, Area 3 \\
\hline \multicolumn{3}{|c|}{$\begin{array}{l}\text { CAU-402 - Closed } \\
\text { Area } 3 \text { Bldg. } 0353 \text { UST Site. TTR }\end{array}$} \\
\hline $03-02-001-0353$ & UST, Diesel & Bldg. 0353 \\
\hline \multicolumn{3}{|l|}{$\begin{array}{l}\text { CAU-403 - Closed } \\
\text { Area } 3 \text { Second Gas St }\end{array}$} \\
\hline $03-02-004-0360$ & USTs & Second Gas Station \\
\hline \multicolumn{3}{|l|}{$\begin{array}{l}\text { CAU-404 - Closed } \\
\text { Roller Coaster Lagoo }\end{array}$} \\
\hline TA-03-001-TARC & Roller Coaster Lagoons & NW of Antelope Lake \\
\hline TA-21-001-TARC & Roller Coaster North Disposal Trench & NW of Antelope Lake \\
\hline \multicolumn{3}{|c|}{$\begin{array}{l}\text { CAU-405-Closed } \\
\text { Area } 3 \text { Septic Systems, TTR }\end{array}$} \\
\hline 03-05-002-SW03 & Septic Waste System & Area 3 \\
\hline 03-05-002-SW04 & Septic Waste System & Area 3 \\
\hline 03-05-002-SW07 & Septic Waste System & Area 3 \\
\hline \multicolumn{3}{|c|}{$\begin{array}{l}\text { CAU-406 - Closed } \\
\text { Area } 3 \text { Bldg. 03-74 and Bldg. 03-58 UDPs, TTR }\end{array}$} \\
\hline $03-51-002-0374$ & Heavy Duty Shop UDP, Sumps & Bldg. 0374 \\
\hline $03-51-003-0358$ & UPS Building UDP & UPS Building, Area 3 \\
\hline \multicolumn{3}{|l|}{$\begin{array}{l}\text { CAU-407 - Closed } \\
\text { Roller Coaster Rad S }\end{array}$} \\
\hline TA-23-001-TARC & Roller Coaster Rad Safe Area & Northwest of Antelope Lake \\
\hline \multicolumn{3}{|c|}{$\begin{array}{l}\text { CAU-408 - Not Started } \\
\text { Bomblet Target Area. TTR }\end{array}$} \\
\hline TA-55-002-TAB2 & Bomblet Target Areas & Antelope Lake \\
\hline \multicolumn{3}{|c|}{$\begin{array}{l}\text { CAU-409-Closed } \\
\text { Other Waste Sites, TTR }\end{array}$} \\
\hline RG-24-001-RGCR & Battery Dump Site & Cactus Repeater \\
\hline TA-53-001-TAB2 & Septic Sludge Disposal Pit & Bunker 2 \\
\hline TA-53-002-TAB2 & Septic Sludge Disposal Pit & Bunker 2 \\
\hline \multicolumn{3}{|c|}{$\begin{array}{l}\text { CAU-410 - Closed } \\
\text { Area } 9 \text { Underground Vault and Disposal Trench. TTR }\end{array}$} \\
\hline 09-21-001-09MG & Former Bunker or Underground Vault & East of Area 9 Magazines \\
\hline 09-21-001-TA09 & Disposal Trenches & Area 9 \\
\hline TA-19-002-TAB2 & Debris Mound & Bunker 2 \\
\hline TA-21-003-TANL & Disposal Trench & NEDS Lake \\
\hline TA-21-002-TAAL & Disposal Trench & South Antelope Lake \\
\hline
\end{tabular}

Refer to notes at end of table. 
TABLE 3-1. DOE/NNSA/NSO ER Project TTR CAUs and CASs CY 2004 Status (continued)

\begin{tabular}{|c|c|c|}
\hline \multicolumn{3}{|c|}{ Industrial Sites CAUs/CASs } \\
\hline CAS Number & CAS Description & General Location \\
\hline \multicolumn{3}{|c|}{$\begin{array}{l}\text { CAU-423-Closed } \\
\text { Area } 3 \text { UDP, Bldg. 0360. TTR }\end{array}$} \\
\hline $03-02-002-0308$ & UDP & \multirow{2}{*}{$\begin{array}{l}\text { Bldg. } 0360 \\
\text { Bldg. } 0360\end{array}$} \\
\hline 03-02-002-0308 & UDP & \\
\hline \multicolumn{3}{|l|}{$\begin{array}{l}\text { CAU-424- Closed } \\
\text { Area } 3 \text { Landfill Com }\end{array}$} \\
\hline 03-08-001-A301 & Landfill Cell A3-1 & Area 3 Landfill Complex \\
\hline 03-08-002-A302 & Landfill Cell A3-2 & Area 3 Landfill Complex \\
\hline 03-08-002-A303 & Landfill Cell A3-3 & Area 3 Landfill Complex \\
\hline 03-08-002-A304 & Landfill Cell A3-4 & Area 3 Landfill Complex \\
\hline 03-08-002-A305 & Landfill Cell A3-5 & Area 3 Landfill Complex \\
\hline 03-08-002-A306 & Landfill Cell A3-6 & Area 3 Landfill Complex \\
\hline 03-08-002-A307 & Landfill Cell A3-7 & Area 3 Landfill Complex \\
\hline 03-08-002-A308 & Landfill Cell A3-8 & Area 3 Landfill Complex \\
\hline \multicolumn{3}{|c|}{$\begin{array}{l}\text { CAU-425 - Closed } \\
\text { Area } 9 \text { Main Lake Construction Debris Disposal Area, TTR }\end{array}$} \\
\hline 09-08-001-TA09 & Construction Debris Disposal Area & Area 9/Main Lake \\
\hline \multicolumn{3}{|c|}{$\begin{array}{l}\text { CAU-426 - Closed } \\
\text { Cactus Spring Waste Trenches, TTR }\end{array}$} \\
\hline RG-08-001-RGCS & Waste Trenches & Cactus Spring Ranch \\
\hline \multicolumn{3}{|c|}{$\begin{array}{l}\text { CAU-427 - Closed } \\
\text { Area } 3 \text { Septic Waste Systems } 2 \text { and 6. TTR }\end{array}$} \\
\hline 03-05-002-SW02 & Septic Waste System No. 2 & Area 3 \\
\hline 03-05-002-SW06 & Septic Waste System No. 6 & Area 3 \\
\hline \multicolumn{3}{|c|}{$\begin{array}{l}\text { CAU-428 - Closed } \\
\text { Area } 3 \text { Septic Waste Systens } 1 \text { and } 5 \text {, TTR }\end{array}$} \\
\hline 03-05-002-SW01 & Septic Waste System No. 1 & Area 3 \\
\hline 03-05-002-SW05 & Septic Waste System No. 5 & Area 3 \\
\hline \multicolumn{3}{|c|}{$\begin{array}{l}\text { CAU-429 - Closed } \\
\text { Area } 3 \text { Bldg. 03-55 and Area } 9 \text { Bldg. 09-52 UDPs, TTR }\end{array}$} \\
\hline $03-51-001-0355$ & Photo Shop UDPs, Drains & Photo Shop Area 3 \\
\hline 09-51-001-0952 & Mobile Photographic Lab UDPs & Area 9 \\
\hline \multicolumn{3}{|c|}{$\begin{array}{l}\text { CAU-430 - Closed } \\
\text { DUArtillery Round \#1.TTR }\end{array}$} \\
\hline TA-55-003-0960 & DU Artillery Round & South of Area 9 \\
\hline $\begin{array}{l}\text { CAU-453 - Closed } \\
\text { Area } 9 \text { UXO Landfi }\end{array}$ & & \\
\hline $09-55-001-0952$ & Area 9 Landfill & Area 9 \\
\hline $\begin{array}{l}\text { CAU-461-Closed } \\
\text { Test Area JTA Sites }\end{array}$ & & \\
\hline TA-52-002-TAML & DU Impact Site & Main Lake \\
\hline TA-52-003-0960 & DU Artillery Round \#2 & South of Area 9 \\
\hline TTR-001 & 1987 W-79 JTA & Unknown - South of Area 9 \\
\hline $\begin{array}{l}\text { CAU-484 - Investi } \\
\text { Antelope and NED }\end{array}$ & $\begin{array}{l}\text { Phase } \\
\text { Waste Sites. TTR }\end{array}$ & \\
\hline TA-52-001-TANL & NEDS Detonation Area & NEDS Lake \\
\hline TA-52-004-TAAL & Metal Particle Dispersion Test & Antelope Lake \\
\hline TA-52-005-TAAL & JTA DU Sites & Antelope Lake \\
\hline TA-54-001-TANL & Rocket Propellant Burn Area & NEDS Lake \\
\hline RG-52-007-TAML & Davis Gun Site - Mellan & Test Range \\
\hline TA-52-006-TAPL & DU Surface Debris & Colimbo Detonation Area, NEDS Lake \\
\hline
\end{tabular}


TABLE 3-1. DOE/NNSA/NSO ER Project TTR CAUs and CASs CY 2004 (concluded)

\begin{tabular}{|c|c|c|}
\hline \multicolumn{3}{|c|}{ Industrial Sites CAUs/CASs } \\
\hline CAS Number & CAS Description & General Location \\
\hline \multicolumn{3}{|c|}{$\begin{array}{l}\text { CAU-485 - Closed } \\
\text { Cactus Spring Ranch Pu and DU Site. TTR }\end{array}$} \\
\hline TA-39-001-TAGR & Cactus Spring Ranch, Soil Contamination & West of Target Areas \\
\hline \multicolumn{3}{|c|}{$\begin{array}{l}\text { CAU-486 - Closed } \\
\text { Double Tracks Rad Safe Area. Nellis Range 71 North }\end{array}$} \\
\hline $71-23-001-71 \mathrm{DT}$ & Double Tracks Rad Safe Area & Nellis Range 71 North \\
\hline \multicolumn{3}{|c|}{$\begin{array}{l}\text { CAU-487 - Closed } \\
\text { Thunderwell Site, TTR }\end{array}$} \\
\hline RG-26-001-RGRV & Thunderwell Site & Thunderwell Site \\
\hline \multicolumn{3}{|c|}{$\begin{array}{l}\text { CAU-489 - Investigation Phase } \\
\text { WWUI UXO Sites. TTR }\end{array}$} \\
\hline RG-55-001-RGMN & WWII Ordnance Site & Mellan Airstrip \\
\hline RG-55-002-RGHS & WWII Ordnance Site & H-Site Road \\
\hline RG-55-003-RG36 & WWII Ordnance Site & Gate $36 \mathrm{E}$ \\
\hline \multicolumn{3}{|c|}{$\begin{array}{l}\text { CAU-490 - Closed } \\
\text { Station } 44 \text { Burn Area, TTR }\end{array}$} \\
\hline RG-56-001-RGBA & Fire Training Area & Station 44 \\
\hline 03-56-001-03BA & Fire Training Area & Area 3 \\
\hline $03-58-001-03 \mathrm{FN}$ & Sandia Service Yard & Area 3 \\
\hline 09-54-001-09L2 & Solid Propellant Burn Site & Area 9 \\
\hline \multicolumn{3}{|c|}{$\begin{array}{l}\text { CAU-495 - Closed } \\
\text { Unconfirmed JTA Sites. TTR }\end{array}$} \\
\hline TA-55-006-09SE & Buried Artillery Round & Test Area \\
\hline TA-55-007-09SE & Buried Artillery Round & Test Area \\
\hline \multicolumn{3}{|c|}{$\begin{array}{l}\text { CAU-496-Investigation Phase } \\
\text { Buried Rocket Site - Antelone Lake. TTR }\end{array}$} \\
\hline TA-55-008-TAAL & Buried Rocket & Antelope Lake \\
\hline \multicolumn{3}{|c|}{$\begin{array}{l}\text { CAU-499 - Closed } \\
\text { Hydrocarbon Spill Site, TTR }\end{array}$} \\
\hline RG-25-001-RD24 & Hydrocarbon Spill Site & Radar 24 Site \\
\hline \multicolumn{3}{|c|}{ Soil Sites CAUs/CASs: } \\
\hline \multicolumn{3}{|c|}{$\begin{array}{l}\text { CAU-411 - Closed } \\
\text { Double Tracks Plutonium Dispersion. Nellis }\end{array}$} \\
\hline NAFR-23-01 & Pu-contaminated Soil & Double Tracks \\
\hline \multicolumn{3}{|l|}{$\begin{array}{l}\text { CAU-412 - Closed } \\
\text { Clean Slate } 1 \text { Plutonil }\end{array}$} \\
\hline TA-23-01CS & Pu-Contaminated Soil & Clean Slate 1 \\
\hline \multicolumn{3}{|c|}{$\begin{array}{l}\text { CAU-413 - Remediation Phase } \\
\text { Clean Slate } 2 \text { Plutonium Dispersion. TTR }\end{array}$} \\
\hline TA-23-02CS & Pu-Contaminated Soil & Clean Slate 2 \\
\hline \multicolumn{3}{|c|}{$\begin{array}{l}\text { CAU-414 - Not Started } \\
\text { Clean Slate } 3 \text { Plutonium Dispersion. TTR }\end{array}$} \\
\hline TA-23-03CS & Pu-Contaminated Soil & Clean Slate 3 \\
\hline
\end{tabular}

SOURCE: DoD/DOE/State of NV 1996 and ongoing updates

NOTE: $\quad$ DOE $=$ U.S. Department of Energy

$\mathrm{CAU}=$ Corrective Action Unit

$\mathrm{CAS}=$ Corrective Action Site

NNSA $=$ National Nuclear Security Administration

$\mathrm{DU}=$ depleted uranium

$\mathrm{ER}=$ Environmental Restoration

NEDS $=$ Non-Explosive Destruction Site

WWII $=$ World War II

$\mathrm{NSO}=$ Nevada Site Office

UDP $=$ underground discharge points

UST $=$ underground storage tank

$\mathrm{UXO}=$ unexploded ordnance

TTR $=$ Tonopah Test Range

$\mathrm{Pu}=$ Plutonium

JTA $=$ Joint Test Assembly 
or mixed waste was generated during ER activities at TTR or disposed during 2004. One drum of nonimpacted personal protective equipment (PPE) was disposed of at the U.S. Air Force (USAF) sanitary landfill in 2004. No sanitary rinsate was disposed of in the TTR sanitary lagoons in 2004. Westinghouse Government Service participates in environmental cleanup and restoration activities.

\subsection{WASTE MANAGEMENT PROGRAMS}

All waste generated by Sandia Corporation activities at TTR is managed by Westinghouse Government Service under the Waste Management Program. (Sandia Corporation does not handle waste generated by ER activities.) Waste categories include radioactive waste, RCRA-hazardous waste, other chemical waste, and non-hazardous solid waste. Waste minimization and recycling efforts are integrated into Waste Management Program activities. Waste generated and handled by Sandia Corporation at TTR in 2004 was as follows:

\begin{tabular}{lc}
$\begin{array}{l}\text { Waste Type } \\
\text { RCRA hazardous waste }\end{array}$ & \multicolumn{1}{c}{ Weight } \\
Non-RCRA-regulated & $3,768 \mathrm{~kg}(8,306 \mathrm{lb})$ \\
Recycled Waste & $3,671 \mathrm{~kg}(8,093 \mathrm{lb})$ \\
Radioactive waste & $0 \mathrm{~kg}$
\end{tabular}

Sandia Corporation shipped all regulated waste to off-site permitted TSD facilities.

Table 3-2 shows a detailed breakdown of the RCRA waste categories and quantities. Table 3-3 lists regulated non-RCRA waste categories and quantities. Table 3-4 lists waste categories transported off-site for recycling or alternative fuel use. A Hazardous Waste Biennial Report is prepared by SNL/NM and submitted to the U.S Environmental Protection Agency (EPA) through DOE/NNSA/NSO (SNL 2004a).

\section{Waste Minimization Program}

TTR is committed to achieving significant reductions in the amount of chemical and hazardous wastes generated on-site. Waste minimization includes recycling and recovery of the following materials:

- Solvents,

- Fuels and oil,
- Antifreeze (on-site recycling unit),

- Lead acid batteries,

- Freon (on-site recovery unit),

- Fluorescent and sodium bulbs, and

- Mercury-containing equipment.

Recyclable waste and used oil was sent for recycling or disposed of through the waste disposal contractor.

\section{Radioactive Waste Management}

There were no shipments of radioactive waste in 2004.

\subsection{SPILL PREVENTION CONTROL AND COUNTERMEASURES (SPCC) PLAN}

The SPCC Plan for SNL Tonopah Test Range (SNL 1999), which was revised in 2004, pertains to oil storage equipment and secondary containments subject to 40 CFR 112, "Oil Pollution Prevention" and 40 CFR 110, "Discharge of Oil."

There are three aboveground storage tanks (ASTs), two bulk storage areas (BSA), and one transformer storage area that are regulated with a capacity of greater than 660 gallons that are applicable to the SPCC Plan at TTR.

\subsection{NEPA PROGRAM}

\section{NEPA Activities at TTR}

At TTR, NEPA compliance is coordinated between Sandia Corporation at TTR, Sandia Corporation at Sandia National Laboratories, New Mexico (SNL/NM), and DOE/NNSA, Sandia Site Office (SSO). Additionally, under the direction of Sandia Corporation, compliance is supported by the Water Resources Center at the Desert Research Institute (DRI) through the University of Nevada System. DRI prepares archaeological and biological surveys and reports. Final reports are submitted to Sandia Corporation for transmittal to DOE/NNSA/SSO for review and decision-making and consultation with state and federal agencies.

The Final Environmental Impact Statement (EIS) for the NTS and Off-Site Locations in the State of Nevada, which includes the TTR site, was completed in 1996; the DOE Record of Decision (ROD) was filed on December 9, 1996 (DOE 1996). 
TABLE 3-2. Sandia Corporation TTR Generated RCRA-Regulated Hazardous Waste Shipped Off-site in 2004

\begin{tabular}{|c|c|c|}
\hline Waste Description & Waste Codes & $\begin{array}{c}\text { Generated } \\
\text { (lb) }\end{array}$ \\
\hline \multicolumn{3}{|l|}{ WASTE MANAGEMENT } \\
\hline Waste Toxic Solid, Organic, NOS & D035, F002, F005 & 50 \\
\hline Waste (Lithium Battery) & D001, D003 & 5 \\
\hline Waste Aerosols & D001 & 122 \\
\hline Waste Paint Related Material & D001 & 165 \\
\hline Waste Flammable Liquids & D001 & 169 \\
\hline Waste Flammable Liquids, NOS & D001, D035 & 715 \\
\hline Waste, Gasoline/Diesel Fuel & D001, D018 & 25 \\
\hline Waste Diesel Fuel & D001 & 60 \\
\hline Waste Corrosive Liquid, Basic, Inorganic, NOS & D002, D007, D011 & 200 \\
\hline Waste Corrosive Liquid, Organic, NOS & D002, D010 & 10 \\
\hline Hazardous Waste, Solid, NOS & D008 & 170 \\
\hline Hazardous Waste, Solid, NOS & D008, D009 & 121 \\
\hline Hazardous Waste, Liquid, NOS & D007, D011 & 186 \\
\hline Hazardous Waste, Liquid, NOS & D006, D007, D011 & 80 \\
\hline \multicolumn{2}{|c|}{$\begin{array}{lll} & \text { TOTAL }\end{array}$} & 2,078 \\
\hline
\end{tabular}

TTR = Tonopah Test Range

$\mathrm{lb}=$ pounds

TABLE 3-3. Non-RCRA-Regulated Hazardous or Toxic Waste Shipped Off-site in 2004

\begin{tabular}{|c|c|c|c|}
\hline Waste Description & Waste Codes & Shipped & Generated (Ib) \\
\hline Non-Reg Solid Waste & $\mathrm{NCR}$ & & 7,510 \\
\hline Non-Reg Liquid Waste & NCR & & 730 \\
\hline Environmentally Hazardous Substances, & NCR & & 35 \\
\hline Polychlorinated Biphenyl's (PCB) Ballasts & TSCA & & 31 \\
\hline & & TOTAL & 8,306 \\
\hline D\&D Asbestos Waste & TSCA & $8 \mathrm{yd}^{3}$ & $8 \mathrm{yd}^{3}$ \\
\hline Environmental Restoration (ER) & & & \\
\hline Hydrocarbon impacted soil \& debris & & & 0 \\
\hline IDW & & 200 & 200 \\
\hline LLW (soil, debris, and PPE) & & & 0 \\
\hline Inert UXO debris & & & 0 \\
\hline & & TOTAL & 200 \\
\hline NOTE: $\mathrm{NCR}=$ no code required & & \multirow{4}{*}{\multicolumn{2}{|c|}{$\begin{array}{l}\text { TSCA }=\text { Toxic Substances Control Act } \\
\text { LLW }=\text { low level waste } \\
\text { UXO }=\text { unexploded ordnance } \\
\text { PPE }=\text { personal protective equipment } \\
\quad l b=\text { pounds }\end{array}$}} \\
\hline RCRA $=$ Resource Conservation and Recovery Act & & & \\
\hline IDW = Investigation-Derived Waste & & & \\
\hline $\begin{array}{l}D \& D=\text { decontamination and demolition } \\
y^{3}=\text { cubic yard }\end{array}$ & & & \\
\hline
\end{tabular}

TABLE 3-4. Recycled Regulated Hazardous or Toxic Waste Shipped Off-site in 2004

\begin{tabular}{|l|r|}
\hline \multicolumn{1}{|c|}{ Recycled Material or Energy Recovered Material } & Generated (lb) \\
\hline Batteries Wet, Filled with Acid & 645 \\
\hline Lead For Recycle & 5 \\
\hline Automotive Batteries & 5,978 \\
\hline Batteries Dry Containing Potassium Hydroxide Solid & 655 \\
\hline Fluorescent Lights & 360 \\
\hline Used Oil & 370 \\
\hline Antifreeze (Ethylene Glycol) & 30 \\
\hline Circuit Boards for Recycle & 50 \\
\hline
\end{tabular}

NOTE: $1 b=$ pounds 


\section{NEPA Documentation}

A total of six NEPA reviews were processed during 2004. Two NEPA reviews were completed by SNL/NM. Four NEPA checklists were submitted to SSO for review. Three of these checklists were found to be categorically excluded and one NEPA checklist is pending a decision at SSO.

\subsection{ENVIRONMENTAL MONITORING PERFORMED BY OUTSIDE AGENCIES}

In addition to Sandia Corporation, other agencies perform environmental monitoring activities at TTR, as described below.

\section{EPA}

The EPA Environmental Monitoring Systems Laboratory in Las Vegas, NV, monitored background radiation in the area of TTR as part of its Off-site Radiation Monitoring Reports Program (EPA 1999), which is now being done by DRI.

\section{DRI, University of Nevada System}

The DRI trains and provides monitoring station managers (generally they are local science teachers) to run the EPA air monitoring equipment set up at locations within the local community including the towns of Tonopah and Goldfield. The EPA laboratory in Las Vegas, Nevada provides the equipment and performs the analysis and reporting.

DRI also provides external quality assurance (QA) on field measurements taken by the EPA at these community-monitoring stations. DRI monitors selected locations concurrently using a portable monitoring station (PMS) and thermoluminescent dosimeters (TLDs). DRI's Community Radiation Monitoring Program Annual Report now appears as part of the NTS Annual Site Environmental Report (ASER) (DOE 2004).

DRI also performs other monitoring-primarily hydrological - for the DOE, as requested. This may include evaluating environmental impacts due to construction projects at TTR.

\section{Westinghouse Government Service}

As part of its TTR support activities, Westinghouse Government Service personnel perform environmental monitoring activities for DOE and/or Sandia Corporation when needed as follows:
- Drinking water and wastewater sampling;

- National Emission Standards for Hazardous Air Pollutants (NESHAP) 40 CFR 61, Subpart H (radionuclides) air quality monitoring;

- Soil sampling and site characterization of spill sites;

- Waste sampling and characterization; and

- ER support activities.

\subsection{SUMMARY OF RELEASE REPORTING}

The following four release reporting documents must be submitted to external regulatory agencies if releases exceed applicable threshold quantities (TQ):

- NESHAP Annual Report for CY 2004, SNL/NV (SNL 2005), requires that an annual report be submitted from each DOE/NNSA site where facility sources contribute a public dose of over $0.1 \mathrm{mrem} / \mathrm{yr}$. The NESHAP report must be submitted to the EPA by June 30th each year, following the reporting year. The report includes the calculated effective dose equivalent (EDE) in mrem/yr for the maximally exposed individual (MEI).

- State of Nevada Reports - The State of Nevada requires copies of each hazardous waste manifest that accompanies each waste shipment.

- State of Nevada Extremely Hazardous Material Reporting Requirements - This is not currently required since Sandia Corporation does not use any extremely hazardous materials during its routine operations.

- Toxic Chemical Release Reporting Community Right-to-Know: Calendar Year 2004 (SNL 2004) submitted for lead released at the TTR firing range. 


\section{chapter four}

\section{TTR ENVIRONMENTAL MONITORING}

In This Chapter ...

Terrestrial Surveillance

Water Monitoring

Radiological Air Monitoring

Non-radiological Air Emissions

Environmental Snapshot

Soil is the only terrestrial medium sampled at TTR. There are no bodies of water, other than the playa lakes (dry lake beds with only occasional standing water), and vegetation is scarce.
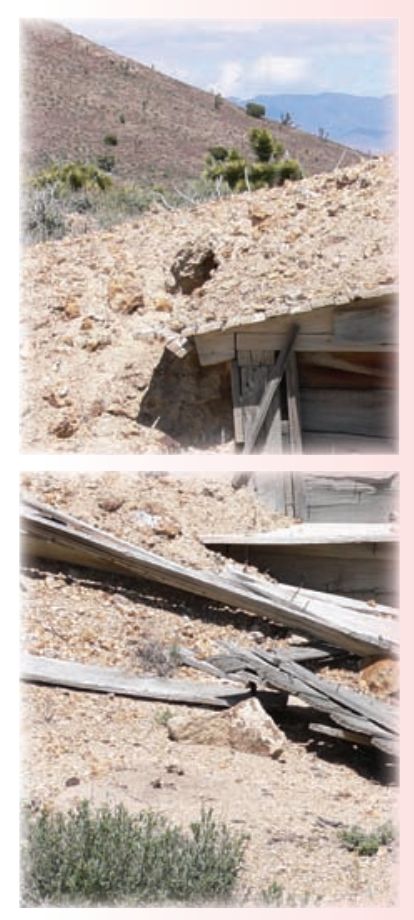
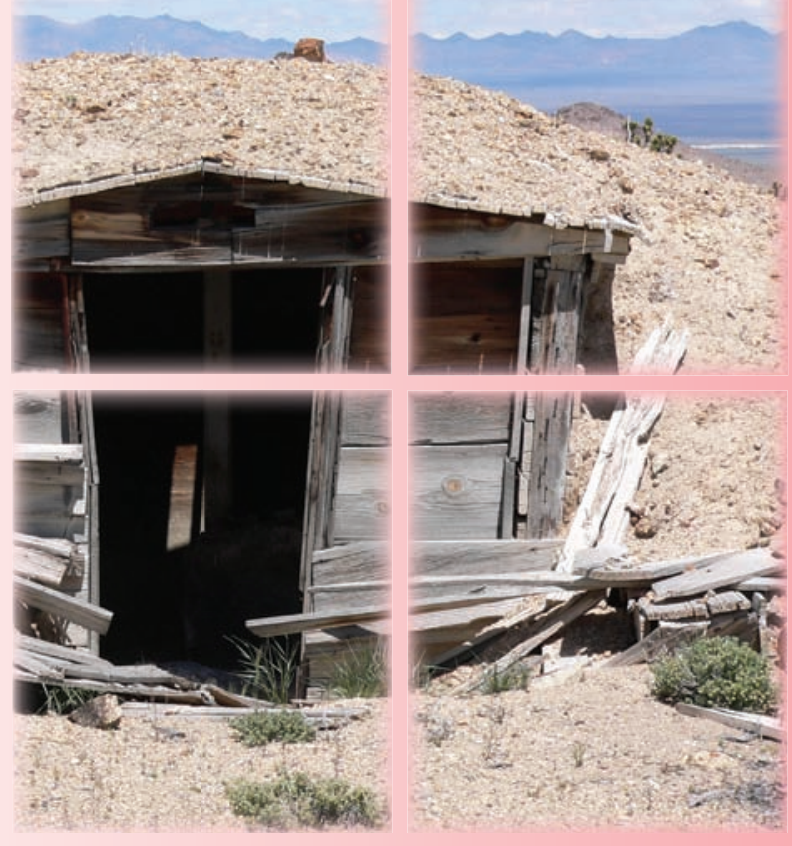


\subsection{TERRESTRIAL SURVEILLANCE}

Terrestrial surveillance is conducted at the Tonopah Test Range (TTR) to detect the possible migration of contaminants to off-site locations and to determine the potential impact of Sandia Corporation's operations on human health or the environment.

\subsubsection{Program Objectives}

The objectives of the Terrestrial Surveillance Program can be summarized by the following excerpts of the requirements given in U.S. Department of Energy (DOE) Order 450.1, Environmental Protection Program (DOE 2005):

- Collect and analyze samples to characterize environmental conditions and define increasing or decreasing trends;

- Establish background levels of pollutants to define baseline conditions (off-site sampling);

- Provide continuing assessment of pollution abatement programs;

- Identify and quantify new or existing environmental quality problems and their potential impacts, if any; and

- Verify compliance with applicable environmental laws and regulations and commitments made in National Environmental Policy Act (NEPA) documents, such as Environmental Impact Statements (EISs), as well as other official documents.

\subsubsection{Regulatory Standards and Comparisons}

The Terrestrial Surveillance Program is designed and conducted in accordance with the requirements of DOE Order 450.1, Environmental Protection Program (DOE 2005). Concentration limits for radionuclides and metals in terrestrial media are not well defined; however, the Environmental Management (EM) Department does compare the results from on-site and perimeter locations to off-site results to determine the impact, if any, of Sandia Corporation's operations on the environment. In addition, sample results for metal in surface soils are compared to U.S. surface soil average concentrations, published in Trace Elements in Soils and Plants (Kabata-Pendias and Pendias, 2000), or local/regional surface soil average concentrations, published in Elements in North American Soils (Dragun and Chekiri, 2005).

\subsubsection{Statistical Analyses}

Samples are generally collected from fixed locations to effectively make statistical comparisons with results from previous years. Statistical analyses are performed to determine if a specific result or group of on-site or perimeter results, differs from off-site values, and to identify trends at a specific sampling location. Since multiple data points are necessary to provide an accurate view of a system, the Terrestrial Surveillance Program does not rely on the results from any single year's sampling event to characterize on-site environmental conditions. Results from a single sampling point may vary from year to year, due to slight changes in sampling locations, differences in climatic conditions, and laboratory variations or errors. Therefore, as the amount of data increases, the accuracy of the characterization increases.

The results of the statistical analyses allow the EM Department to prioritize sample locations for possible follow-up action. The prioritization process is a decision-making tool to assist in determining the appropriate level of concern for each sample result. The Statistical Analysis Prioritization Method (Shyr, Herrera, and Haaker, 1998) is based on two "yes or no" questions resulting in a matrix of four priority levels (Table 4-1). In addition, a qualitative, visual inspection of a graphical presentation of the data is conducted to compare sampling results to regional/ local and site-specific concentrations. This step is performed to ensure that anomalous data that would otherwise pass statistical scrutiny is flagged for further investigation.

To date, there have been no terrestrial sample results that have indicated a significant level of concern (Priority-1) that would trigger actions at locations that are not already being addressed by the Environmental Restoration (ER) Project.

In past years, the period of time covered by the statistical analysis was from 1994 to present. In calendar year 2001, the analysis was limited to a five-year period (this year beginning in 1999). The reason for the change was that SNL/NM changed analytical laboratories in 2000, with lower detection capabilities for many of the metals and 
TABLE 4-1. Decision Matrix for Determining Priority Action Levels

\begin{tabular}{|c|c|c|c|}
\hline Priority & $\begin{array}{l}\text { Are results higher } \\
\text { than off-site?*}\end{array}$ & $\begin{array}{l}\text { Is there an } \\
\text { increasing trend? }\end{array}$ & Priority for further investigation \\
\hline 1 & tinan oilisite? & Yes & $\begin{array}{l}\text { Immediate attention needed. Specific } \\
\text { investigation planned and/or notifications } \\
\text { made to responsible parties. }\end{array}$ \\
\hline 2 & Yes & No & $\begin{array}{l}\text { Some concern based on the level of con- } \\
\text { taminant present. Further investigation } \\
\text { and/or notifications as necessary. }\end{array}$ \\
\hline 3 & No & Yes & $\begin{array}{l}\text { A minor concern since contaminants } \\
\text { present are not higher than off-site } \\
\text { averages. Further investigation and/or } \\
\text { notifications as necessary. }\end{array}$ \\
\hline 4 & No & No & No concern. No investigation required. \\
\hline
\end{tabular}

radiological analyses. As a result, a large number of false decreasing trends were noted for many of the parameters when the whole data set was analyzed. By limiting the analysis to a five-year period, the number of apparent decreasing trends was reduced, and should be eliminated over the next couple of years.

\subsubsection{Sampling Locations}

Terrestrial surveillance began at TTR in 1992. In addition to routine sampling, a large-scale baseline sampling was performed in 1994 in areas where Sandia Corporation had a long-term or continued presence.

Routine terrestrial surveillance is conducted at on-site, perimeter, and off-site locations that remain essentially the same from year to year. The sampling locations, number of samples, and analyses performed are prioritized based on the following criteria:

- On-site locations are near areas of known contamination, potential sources of contamination, or in areas where contamination, if present, would be expected to accumulate, such as in the vicinity of ER sites. A list of on-site sampling locations is shown in Table 4-2. Appendix A contains maps of the sampling locations. A total of 21 locations were sampled on-site.

- Off-site locations are selected to provide a measurement of environmental conditions unaffected by Sandia Corporation's activities at TTR. Data collected from off-site locations serve as a reference point to compare data collected at perimeter and on-site locations. Multiple years of sampling data are compiled to determine statistical averages for off-site concentrations. Off-site locations are chosen both in remote, natural settings as well as in areas near local population centers and along highways. Table 4-3 contains a list of the offsite sample locations. The 14 off-site locations sampled are shown in Figure A-1 of Appendix A.

- Perimeter locations are selected to establish if contaminants are migrating either onto or off Sandia Corporation property at TTR. A list of perimeter sampling locations is shown in Table 4-4. A map of the eight perimeter locations is shown in Figure A-2 of Appendix A. All perimeter locations are in areas to which Sandia Corporation does not control access within TTR.

\subsubsection{Radiological Parameters and Results}

Soil is the only terrestrial medium sampled at TTR. There are no bodies of water, other than the playa lakes (dry lake beds with only occasional standing water), and vegetation is scarce. Soil samples are collected to ascertain the presence of air-deposited pollutants or contaminants that have been transported and deposited as a result of surface water runoff. Samples are collected from the top two inches of soil using a hand trowel. The 2004 analytical results are found in Appendix A of this report and are summarized in this section. The detailed statistical analyses are documented in the Tonopah Test Range Data Analysis in Support of the Annual Site Environmental Report, 2004 (SNL 2005a). Radiological parameters include gammaemitting radionuclides, plutonium and uranium. 
TABLE 4-2. On-Site Terrestrial Surveillance Locations at TTR

\begin{tabular}{|c|c|c|c|c|c|c|}
\hline $\begin{array}{c}\text { On-Site } \\
\text { Location }\end{array}$ & $\begin{array}{l}\text { Revised } \\
\text { Location } \\
\text { Number }\end{array}$ & $\begin{array}{c}\text { Old } \\
\text { Location } \\
\text { Number }\end{array}$ & $\begin{array}{c}\text { Sample } \\
\text { Location } \\
\end{array}$ & $\begin{array}{c}\text { Soil } \\
\text { Sampling }\end{array}$ & Replicate & $T L D$ \\
\hline \multirow{5}{*}{$\begin{array}{l}\text { South } \\
\text { Plume }\end{array}$} & $\mathrm{S}-48$ & $\mathrm{~T}-14$ & N/S Mellan Airstrip - Antelope Tuff & $\sqrt{ }$ & $\sqrt{ }$ & \\
\hline & S-49 & T-16 & N/S Mellan Airstrip - SW of S-48 & $\sqrt{1}$ & & \\
\hline & $\mathrm{S}-50$ & T-17 & N/S Mellan Airstrip - sign post & $\sqrt{1}$ & & \\
\hline & S-51 & T-18 & N/S Mellan Airstrip - NE of S-50 & $\sqrt{1}$ & $\sqrt{ }$ & \\
\hline & $\mathrm{S}-52$ & T-19 & NE of NW/SE Mellan Airstrip & $\sqrt{1}$ & & \\
\hline \multirow{8}{*}{$\begin{array}{l}\text { Range } \\
\text { Operations } \\
\text { Center }\end{array}$} & $\mathrm{S}-40$ & OC-02 & Waste Water Monitoring Station & $\frac{1}{\sqrt{3}}$ & & \\
\hline & S-41 & $\mathrm{OC}-03$ & "Danger Powerline Crossing" Sign & $\sqrt{1}$ & & \\
\hline & $\mathrm{S}-42$ & OC-04 & Main Road/Edward's Freeway & $\sqrt{1}$ & & \\
\hline & S-43 & OC-10 & $\begin{array}{l}\text { SW Corner of Sandia Corporation, TTR Opera- } \\
\text { tions Center }\end{array}$ & $\sqrt{ }$ & & \\
\hline & $\mathrm{S}-44$ & OC-13 & $\begin{array}{l}\text { NE Corner of Sandia Corporation, TTR Opera- } \\
\text { tions Center }\end{array}$ & $\sqrt{ }$ & & \\
\hline & $\mathrm{S}-45$ & OC-19 & Storage Shelters, 03-38/03-39 & $\sqrt{1}$ & & \\
\hline & $\mathrm{S}-46$ & OC-22 & Sand Building & $\sqrt{ }$ & & \\
\hline & $\mathrm{S}-47$ & $\mathrm{OC}-23$ & Generator Storage Area & $\sqrt{ }$ & & \\
\hline \multirow{14}{*}{$\begin{array}{l}\text { Various } \\
\text { On-Site } \\
\text { Locations }\end{array}$} & S-01 & $\mathrm{T}-01$ & Antelope Lake Area Fence, Cultural Area Sign & & & $\sqrt{ }$ \\
\hline & $\mathrm{S}-02$ & $\mathrm{~T}-02$ & N/S Mellan Airstrip (TLD at South fence post) & $\sqrt{ }$ & & $\sqrt{ }$ \\
\hline & S-03 & $\mathrm{T}-03$ & TLD at Clean Slate 2 & $\sqrt{ }$ & $\sqrt{ }$ & $\sqrt{1}$ \\
\hline & S-04 & T-04 & TLD at Clean Slate 3 & $\sqrt{ }$ & & $\sqrt{ }$ \\
\hline & S-09 & $\mathrm{D}-10$ & Roller Coaster Decon & $\sqrt{ }$ & $\sqrt{ }$ & $\sqrt{1}$ \\
\hline & $\mathrm{S}-10$ & T-10 & Brownes Road/Denton Freeway & $\sqrt{1}$ & & $\sqrt{1}$ \\
\hline & S-13 & $\mathrm{T}-13$ & Area 3 between Bldg. 100 and Caution Sign & & & $\sqrt{ }$ \\
\hline & S-14 & T-14 & Area 3 CP SW side on fence & & & $\sqrt{1}$ \\
\hline & S-15 & $\mathrm{T}-15$ & $\begin{array}{l}\text { Moody Ave. by cattle guard and entrance to } \\
\text { airnort and chow hall }\end{array}$ & & & $\sqrt{ }$ \\
\hline & S-16 & S-16 & Area 9 by Bldg. 09-08 and LPG storage & & & $\frac{1}{v}$ \\
\hline & S-17 & S-17 & Hard Target area by Bldg. 23-16 & & & $\sqrt{ }$ \\
\hline & S-38 & MH-03 & Mellan Hill - Metal Scrap Pile & $\sqrt{ }$ & & \\
\hline & S-39 & MH-04 & Mellan Hill - North & $\sqrt{ }$ & & \\
\hline & S-53 & $\mathrm{T}-20$ & Main Road/Lake Road SE & $\sqrt{ }$ & & \\
\hline
\end{tabular}

NOTE: $T L D=$ Thermoluminescent Dosimeter $\mathrm{TTR}=$ Tonopah Test Range

$\mathrm{N} / \mathrm{S}=$ North/South (runway runs North/South)

*In addition to single samp $\square$

TABLE 4-3. Off-Site Terrestrial Surveillance Locations at TTR

\begin{tabular}{|c|c|c|c|c|c|c|}
\hline $\begin{array}{l}\text { On-Site } \\
\text { Location }\end{array}$ & $\begin{array}{l}\text { Revised } \\
\text { Location } \\
\text { Number }\end{array}$ & $\begin{array}{c}\text { Old } \\
\text { Location } \\
\text { Number }\end{array}$ & $\begin{array}{c}\text { Sample } \\
\text { Location }\end{array}$ & $\begin{array}{c}\text { Soil } \\
\text { Sampling }\end{array}$ & Replicate & $T L D$ \\
\hline \multirow[t]{16}{*}{ Off-Site } & $\mathrm{C}-18$ & T-18 & Tonopah Old Court House & & & \\
\hline & C-19 & T-19 & Mining Museum, North Goldfield & & & $\sqrt{ }$ \\
\hline & $\mathrm{C}-20$ & B-08 & State Road 6 Rest Area & $\sqrt{ }$ & & \\
\hline & $\mathrm{C}-21$ & $\mathrm{~B}-04$ & State Road 6/95 Rest Area & $\sqrt{ }$ & & $\sqrt{ }$ \\
\hline & $\mathrm{C}-22$ & B-07 & Rocket & $\sqrt{ }$ & & $\sqrt{ }$ \\
\hline & $\mathrm{C}-23$ & B-01 & Alkali/Silver Peak Turnoff & $\sqrt{ }$ & & \\
\hline & $\mathrm{C}-24$ & $\mathrm{~B}-02$ & Cattle Guard & $\sqrt{ }$ & & \\
\hline & $\mathrm{C}-25$ & B-03 & Tonopah Ranger Station & $\checkmark$ & & \\
\hline & C-26 & B-05 & Gabbs Pole Line Road & $\sqrt{ }$ & & \\
\hline & $\mathrm{C}-27$ & B-06 & State Roads 6/376 Junction & $\sqrt{ }$ & & \\
\hline & $\mathrm{C}-28$ & B-09 & Stone Cabin/Willow Creek & $\sqrt{ }$ & & \\
\hline & $\mathrm{C}-29$ & $\mathrm{~B}-10$ & State Roads 6/375 Junction & $\sqrt{ }$ & $\sqrt{ }$ & \\
\hline & $\mathrm{C}-30$ & B-11 & State Road 375 Ranch Cattle Gate & $\frac{v}{V}$ & & \\
\hline & $\mathrm{C}-31$ & $\mathrm{~B}-12$ & Golden Arrow/Silver Bow & $\sqrt{ }$ & & \\
\hline & $\mathrm{C}-32$ & $\mathrm{~B}-13$ & Five miles south of Rocket & $\sqrt{ }$ & & \\
\hline & C-33 & $\mathrm{B}-14$ & Nine miles south of Rocket & $\sqrt{ }$ & & \\
\hline
\end{tabular}

NOTE: $T L D=$ Thermoluminescent Dosimeter

TTR $=$ Tonopah Test Range

*In addition to single samp 
TABLE 4-4. Perimeter Terrestrial Surveillance Locations at TTR

\begin{tabular}{|c|c|c|c|c|c|c|}
\hline $\begin{array}{c}\text { On-Site } \\
\text { Location }\end{array}$ & $\begin{array}{l}\text { Revised } \\
\text { Location } \\
\text { Number }\end{array}$ & $\begin{array}{c}\text { Old } \\
\text { Location } \\
\text { Number }\end{array}$ & $\begin{array}{l}\text { Sample } \\
\text { Location }\end{array}$ & $\begin{array}{c}\text { Soil } \\
\text { Sampling }\end{array}$ & Replicate & $T L D$ \\
\hline \multirow{10}{*}{ Perimeter } & $\mathrm{P}-05$ & T-05 & O\&M Complex - Site 4 Entrance Gate & & & $\sqrt{ }$ \\
\hline & $\mathrm{P}-06$ & T-06 & Cedar Pass Road Guard Station & $\sqrt{ }$ & & $\sqrt{ }$ \\
\hline & $\mathrm{P}-07$ & T-07 & On-Base Housing - SW & & & $\mathrm{V}$ \\
\hline & $\mathrm{P}-08$ & $\mathrm{~T}-08$ & $\begin{array}{l}\text { On-Base Housing (Main guard gate/ } \\
\text { power pole CP17) }\end{array}$ & $\sqrt{ }$ & & V \\
\hline & $\mathrm{P}-11$ & T-13 & Cactus Springs (TLD south of P-35) & $\sqrt{ }$ & $\sqrt{ }$ & $\sqrt{ }$ \\
\hline & $\mathrm{P}-12$ & T-12 & TLD at "US Gov't Property" Sign & $\sqrt{ }$ & & $\sqrt{ }$ \\
\hline & $\mathrm{P}-34$ & OM-03 & O\&M Complex (Owan Drive post) & $\sqrt{ }$ & & \\
\hline & $\mathrm{P}-35$ & T-11 & Cactus Springs (north fence post) & V & & \\
\hline & $\mathrm{P}-36$ & $\mathrm{~T}-36$ & On-Base Housing (NE fence line) & $\sqrt{ }$ & & \\
\hline & P-37 & T-37 & On-Base Housing (guard station) & V & & \\
\hline
\end{tabular}

$\mathrm{TTR}=$ Tonopah Test Range

O\&M = Operations \& Maintenance

*In addition to single samp $\square$

- Gamma-emitting radionuclides - Gamma spectroscopy is used to detect the emission of gamma radiation from radioactive materials. Radionuclide identification is possible by measuring the spectrum of gamma energies associated with a sample, since each radionuclide has a unique and consistent series of gamma emissions. Cesium-137 (Cs-137) is an example of a long-lived gamma emitter that is prevalent in the environment (as fallout from historical nuclear weapons testing). Other gammaemitters of interest at TTR are Americium-241 (Am-241) and depleted uranium (DU) from past explosives testing.

- Plutonium - Due to past explosive testing, plutonium is present in some limited areas of TTR. One of the indicators of the presence of weapons-grade plutonium is the radionuclide Am-241. Isotopic plutonium analysis is normally performed on any sample for which gamma spectroscopy identified Am-241 in concentrations greater than its minimum detectable activity (MDA).

- Uranium - Uranium occurs naturally in soils and may also be present as a pollutant in the environment due to past testing conducted at TTR. Total uranium $\left(\mathrm{U}_{\text {tot }}\right)$ analysis is used to measure all uranium isotopes present in a sample. A high $\mathrm{U}_{\text {tot }}$ measurement may trigger an isotope-specific analysis to determine the possible source of uranium (i.e., natural, manmade, enriched, or depleted).
- External gamma radiation exposure rates Thermoluminescent Dosimeters (TLDs) are used to measure ambient gamma exposure rates. Several natural gamma radiation sources exist, including cosmic radiation and radioactive materials that exist in geologic materials at TTR. The TLD network was established to determine the regional gamma exposure rate due to natural sources and to determine the impact, if any, of Sandia Corporation's operations on these levels. The dosimeters are placed on aluminum poles at a height of approximately one meter, and are exchanged and measured quarterly (January, April, July, and October) at 20 on-site, perimeter and off-site locations.

\section{Radiological Results}

The results of the statistical analysis showed no on-site or perimeter location that was both higher than off-site and with an increasing trend (Priority1). Overall summary statistics for all radiological results are presented in Table 4-5. The following radiological analytes showed one location as Priority-2 (higher than off-site): Am-241, Cs-137, Total Uranium. The Priority-2 locations along with the associated summary statistics are listed in Table 4-6. The following radiological analyte: showed at least one location as Priority-3 (increasing trend): Cs-137 and Total Uranium. While this increasing trend is "statistically significant", it is not operationally significant (does not pose a safety and health threat to human health or the environment). Table 4-7 lists the analytes and their associated summary statistics. It should be noted that plutonium-238 (Pu-238), Pu-239/240, U-235, and U-238 were considered as Priority-4 (not higher than off-site or no increasing trend). 
TABLE 4-5. Summary Statistics for Soil Locations (all units in pCi/g unless otherwise noted)

\begin{tabular}{|c|c|c|c|c|c|c|c|}
\hline Analyte & $\begin{array}{l}\text { Location } \\
\text { Class }\end{array}$ & $\begin{array}{c}\text { Sample } \\
\text { Size }\end{array}$ & Average & Median & Std Dev & Minimum & Maximum \\
\hline \multirow{3}{*}{ Am-241 } & On-site & 105 & 0.138 & 0.014 & 0.555 & -0.162 & 3.580 \\
\hline & Perimeter & 40 & -0.003 & -0.001 & 0.038 & -0.145 & 0.050 \\
\hline & Off-site & 70 & 0.002 & 0.004 & 0.040 & -0.147 & 0.065 \\
\hline \multirow[t]{3}{*}{ Cs-137 } & On-site & 105 & 0.281 & 0.301 & 0.196 & 0 & 0.886 \\
\hline & Perimeter & 70 & 0.211 & 0.161 & 0.159 & 0.012 & 0.573 \\
\hline & Off-site & 40 & 0.238 & 0.200 & 0.165 & 0 & 0.930 \\
\hline \multirow[t]{3}{*}{ Pu-238 } & On-site & 30 & 0.0153 & 0.0071 & 0.0196 & -0.102 & 0.0823 \\
\hline & Perimeter & 8 & 0.0068 & 0.0040 & 0.0088 & 0.0018 & 0.0280 \\
\hline & Off-site & 14 & 0.0058 & 0.0049 & 0.0069 & -0.002 & 0.0238 \\
\hline \multirow{3}{*}{$\begin{array}{l}\text { Pu- } \\
239 / 240\end{array}$} & On-site & 30 & 0.5368 & 0.1180 & 1.1302 & 0.0011 & 4.92 \\
\hline & Perimeter & 8 & 0.0163 & 0.0122 & 0.0141 & 0.0014 & 0.0431 \\
\hline & Off-site & 14 & 0.0115 & 0.0109 & 0.0095 & -0.001 & 0.0319 \\
\hline \multirow[t]{3}{*}{$\mathrm{U}-235$} & On-site & 105 & 0.115 & 0.107 & 0.069 & -0.043 & 0.389 \\
\hline & Perimeter & 40 & 0.097 & 0.083 & 0.059 & 0.017 & 0.252 \\
\hline & Off-site & 70 & 0.097 & 0.083 & 0.062 & -0.005 & 0.293 \\
\hline \multirow[t]{3}{*}{$\mathrm{U}-238$} & On-site & 105 & 1.477 & 1.520 & 0.556 & 0.315 & 3.13 \\
\hline & Perimeter & 40 & 1.363 & 1.335 & 0.608 & 0.048 & 2.65 \\
\hline & Off-site & 70 & 1.481 & 1.450 & 0.591 & 0.178 & 2.96 \\
\hline \multirow{3}{*}{$\begin{array}{l}\text { Total } \\
\text { Uranium } \\
(\mu \mathrm{g} / \mathrm{g})\end{array}$} & On-site & 105 & 0.709 & 0.704 & 0.134 & 0.426 & 1.09 \\
\hline & Perimeter & 40 & 0.705 & 0.677 & 0.184 & 0.483 & 1.49 \\
\hline & Off-site & 70 & 0.740 & 0.691 & 0.200 & 0.463 & 1.44 \\
\hline
\end{tabular}

NOTE: Historical summary of all data for all locations and time (pooled)

The respective radiological analytes are discussed in the sections below listing the locations showing either Priority-2 or Priority-3.

\section{Am-241}

One on-site location (S-09) continues to be identified as Priority-2 (higher than off-site). S-09 is located near the Roller Coaster Decon site. The maximum result for this location was recorded in 2000 and is $3.58 \mathrm{pCi} / \mathrm{g}$. No other on-site locations were identified as Priority-2. No perimeter location was identified as Priority-2 or Priority-3 (increasing trend).

\section{$\underline{\text { Cs-137 }}$}

One on-site location (S-50) continues to be identified as Priority-2 (higher than off-site). S-50 is located near the N/S Mellan Airstrip. The maximum value for Cs-137 was observed in 2003 at $0.767 \mathrm{pCi} / \mathrm{g}$.

One on-site location (S-44) and one perimeter location (P-06) were identified as Priority-3 (increasing trend) for Cs-137. S-44 is located near the northeast corner of the TTR Operations Center for Sandia Corporation. P-06 is located at the Cedar Pass Road Guard Station. The maximum value observed for S-44 was $0.175 \mathrm{pCi} / \mathrm{g}$ while the maximum value for $\mathrm{P}-06$ was $0.221 \mathrm{pCi} / \mathrm{g}$.

\section{Total Uranium ( $\boldsymbol{U}_{\text {tot }}$ )}

There was one perimeter location (P-35) that was identified as Priority-2 (higher than off-site). The maximum value observed at this location was 1.49 $\mu \mathrm{g} / \mathrm{g}$. P-35 is located at Cactus Springs northeast north fence post.

There were three on-site locations (S-09, S-10, and $\mathrm{S}-52$ ) and one perimeter location (P-34) that were identified as Priority-3 (increasing trend). S-09 is located near the Roller Coaster Decon site. S10 is located near the Brownes Road and Denton Freeway. S-52 is located northeast of the NW/SE Mellan Airstrip. P-34 is located at the Owan Drive post near the O\&M Complex. The maximum value from these four locations was noted to be 0.842 $\mu \mathrm{g} / \mathrm{g}$ and was observed at S-52 during the 2004 sampling period.

\section{TLD Results}

Sampling for 2004 was conducted from January 2004 through January 2005. TLDs were missing (not recovered) at several locations during 2004; when a TLD location has a missing quarter the data is not included in the summary statistics. Summary statistics for the past five years are shown in Table 4-8.

On-site and perimeter locations were statistically different from off-site locations; off-site locations are statistically lower than either on-site or perimeter locations. There also appears to be a statistical difference between years with 2004 having the highest recorded results; there appears to be a grouping between 2002 and 2003, which appear to 
TABLE 4-6. Summary Statistics for Soil Locations Noted as Priority-2 (all units in pCi/g unless otherwise noted)

\begin{tabular}{|l|c|c|c|c|c|c|c|}
\hline Analyte & Location & $\begin{array}{c}\text { Sample } \\
\text { Size }\end{array}$ & Average & Median & Std Dev & Minimum & Maximum \\
\hline Am-241 & S-09 & 5 & 2.162 & 2.590 & 1.534 & 0.532 & 3.580 \\
\hline Cs-137 & S-50 & 5 & 0.548 & 0.552 & 0.144 & 0.398 & 0.767 \\
\hline $\begin{array}{l}\text { Total } \\
\begin{array}{l}\text { Uranium } \\
(\boldsymbol{\mu g} / \mathbf{g})\end{array}\end{array}$ & P-35 & 5 & 1.069 & 1.010 & 0.261 & 0.798 & 1.490 \\
\hline
\end{tabular}

TABLE 4-7. Summary Statistics for Soil Locations Noted as Priority-3 (all units in pCi/g unless otherwise noted)

\begin{tabular}{|l|c|c|c|c|c|c|c|}
\hline Analyte & Location & $\begin{array}{c}\text { Sample } \\
\text { Size }\end{array}$ & Average & Median & Std Dev & Minimum & Maximum \\
\hline \multirow{2}{*}{ Cs-137 } & $\mathrm{S}-44$ & 5 & 0.082 & 0.065 & 0.057 & 0.033 & 0.175 \\
\cline { 2 - 7 } & $\mathrm{P}-06$ & 5 & 0.155 & 0.0140 & 0.042 & 0.113 & 0.221 \\
\hline \multirow{2}{*}{$\begin{array}{l}\text { Total } \\
\text { Uranium }\end{array}$} & $\mathrm{S}-09$ & 5 & 0.606 & 0.612 & 0.042 & 0.543 & 0.648 \\
\cline { 2 - 7 } & $\mathrm{S}-10$ & 5 & 0.764 & 0.786 & 0.065 & 0.661 & 0.831 \\
\cline { 2 - 7 } & $\mathrm{S}-52$ & 5 & 0.752 & 0.786 & 0.108 & 0.579 & 0.842 \\
\cline { 2 - 8 } & $\mathrm{P}-34$ & 5 & 0.683 & 0.760 & 0.136 & 0.519 & 0.820 \\
\hline
\end{tabular}

TABLE 4-8. Summary Statistics for TLDs by Location Class (all units in mrem unless otherwise noted)

\begin{tabular}{|l|c|c|c|c|c|c|}
\hline $\begin{array}{l}\text { Location } \\
\text { Class }\end{array}$ & $\begin{array}{c}\text { Sample } \\
\text { Size }\end{array}$ & Average & Median & Std Dev & Minimum & Maximum \\
\hline On-site & 58 & 153.6 & 151.2 & 14.7 & 125.4 & 191.7 \\
\hline Perimeter & 17 & 149.2 & 151.7 & 17.2 & 100.0 & 173.8 \\
\hline Off-site & 16 & 139.5 & 143.3 & 15.2 & 105.1 & 163.2 \\
\hline
\end{tabular}

be statistically greater than the grouping between 2000 and 2001. Figure 4-1 graphically portrays the TLD results from 2000 through 2004. TLD results and TLD measurements by quarter and location type for 2004 are show in Tables A-7 and A-8 of Appendix A, respectively.

\subsubsection{Non-Radiological Parameters and Results}

No non-radiological samples were collected in 2004.

\subsection{WATER MONITORING}

Results for potable water, wastewater effluent sampling, and the issue of storm water monitoring are discussed in this section.

The Water Conservation Plan for the Tonopah Test Range complies with State Water Resources Division regulations requiring a water conservation plan for permitted water systems and major water users in Nevada (DOE 1992).

\subsubsection{Production Well Monitoring}

There are three active wells used by Sandia Corporation at TTR. Production Well 6, Well 7, and the Roller Coaster Well. Production Well 6 and the Roller Coaster Well are the most active. Production Well 6, which supplies drinking water to the Sandia Corporation Main Compound in Area 3, is the only well that has been sampled for contaminants. Outlying areas use bottled water. The other wells are not used for potable purposes (construction and dust suppression) and there is no regulatory sampling requirement.

All sampling is conducted in accordance with requirements set by the state (State of Nevada 1997). Analytes are sampled at different intervals, as shown in Table 4-9.

Sampled parameters included, but were not limited to, total coliforms, nitrates, nitrites, volatile organic compounds (VOCs), lead, copper, and arsenic.

Sandia Corporation remained in compliance with all Well 6 permit requirements in 2004 with one exception: samples for Disinfectant Byproduct 


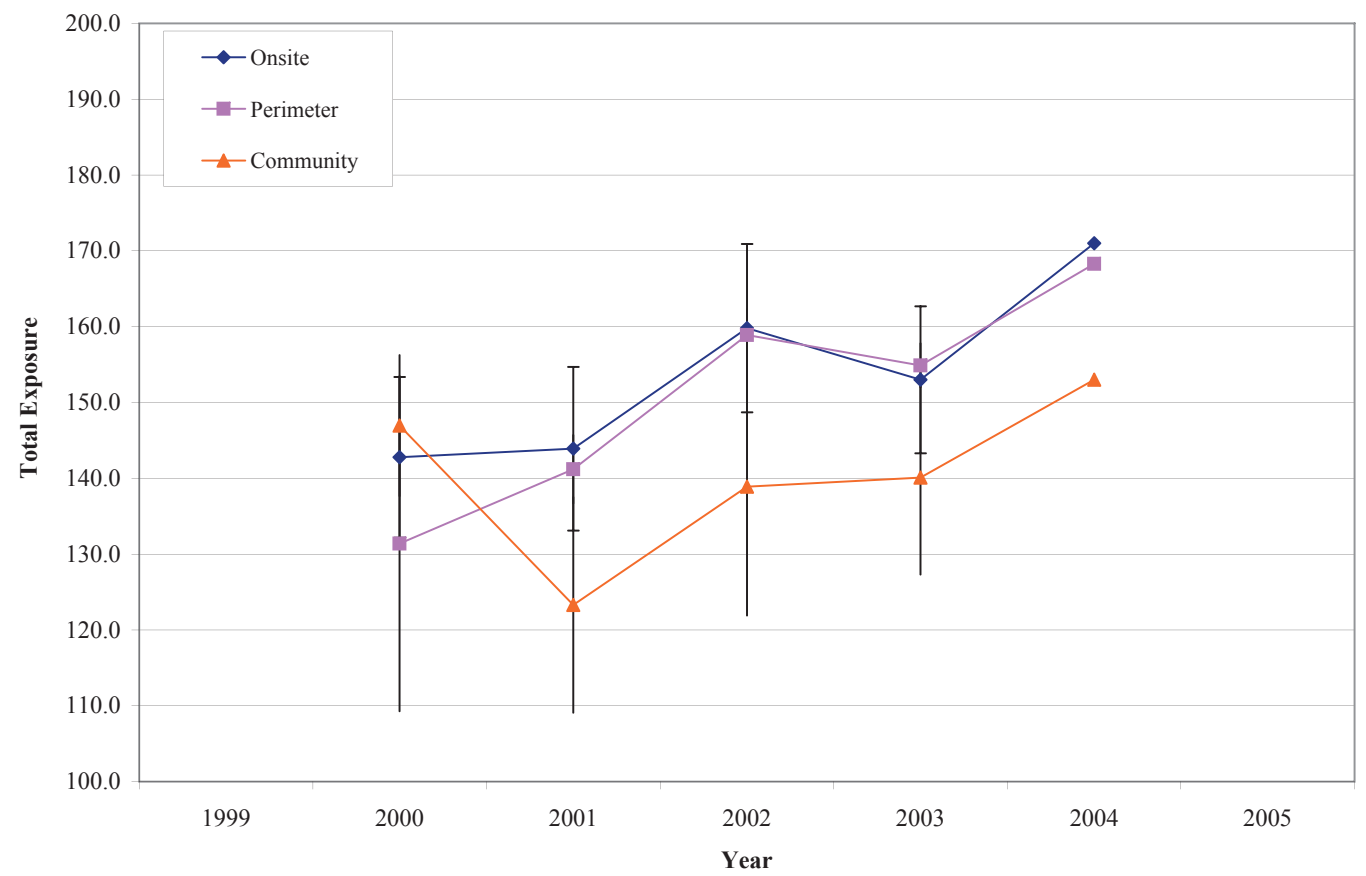

FIGURE 4-1. Tonopah Test Range TLD Exposure (1999-2004)

Monitoring (Trihalomathanes and Haloacetic Acids were required to be collected in July 2004 and was overlooked until October 2004). The state was immediately notified and TTR is awaiting a decision of any corrective action required.

In 2004, work continued on upgrading the TTR Area III Water System (The TTR Water and Fire Protection Project). Additional sampling was accomplished to determine specific treatment options for removal of arsenic and potential treatment to secondary standard SDWA requirements. As of this time, contracts have been let and work will proceed in January of 2005.

\subsubsection{Sewage System and Septic Tank Monitoring}

Sewage from Sandia Corporation's facilities in the Main Compound at Area 3 goes to the USAF facultative sewage lagoon. Either SNL/NM or Westinghouse Government Service takes annual wastewater samples from Area 3 at the point wastewater leaves Sandia Corporation property and enters the USAF system.

The USAF holds the NPDES permit for its wastewater discharges. The USAF takes quarterly samples from the headwater end of the lagoon. In the past, Sandia Corporation provided quarterly sampling results to the USAF for inclusion into their USAF Discharge Monitoring Report (DMR); however, the NPDES permit was modified in 1997 and no longer stipulates the requirement of quarterly data from Sandia Corporation. Therefore, Sandia Corporation now only provides annual sample results to the USAF.

Forty eight hour composite wastewater samples are collected on an annual basis and have the following parameters analyzed:

- Total coliforms;

- Total cyanide (Sandia Corporation does not use cyanide-containing compounds at TTR);

- $\mathrm{pH}$ (potential of hydrogen [acidity]) and nonfiltered residue;

- Phenolics (Sandia Corporation does not use phenol-containing compounds at TTR);

- $\quad$ Chemical oxygen demand (COD);

- VOCs;

- Semi-Volatile Organic Compounds (SVOCs);

- Metals (cadmium, chromium, copper, nickel, silver, zinc, lead, selenium, and mercury);

- Total recoverable petroleum hydrocarbons (TRPH);

- Oil and grease; and 
- Tritium, gamma spectroscopy, gross alpha, and gross beta.

All analytical results for wastewater sampled at Area 3 were within regulatory limits in 2004.

\section{Septic Tank Systems}

Septic tank systems are sampled, as needed. There are six septic systems located on-site, which are owned by Sandia Corporation at TTR. These six active septic tanks are used in remote locations and are maintained by the TTR facilities group. The sewage from these locations flows into septic tanks and associated drain fields. None of these systems required maintenance, sampling, or pumping in 2004. All other remaining septic systems have been closed or are undergoing closure and are being addressed by the ER Project.

\subsubsection{Storm Water Monitoring}

Currently, Sandia Corporation has no requirement to perform storm water monitoring at TTR. All storm water issues and monitoring are managed by the USAF.

\subsection{RADIOLOGICAL AIR MONITORING}

Air quality compliance at the TTR is met by adherence to specific permit conditions and compliance with local, state, and federal air regulations. Ambient air quality monitoring is not currently required at TTR. Ambient air monitoring was last conducted in 1996 to ascertain the level of radiological constituents in the air as discussed below.
Operations by Sandia Corporation at TTR do not involve activities that release radioactive emissions from either point sources (stacks and vents) or diffuse sources such as outdoor testing. However, diffuse radiological emissions are produced from the re-suspension of americium and plutonium present at the Clean Slate ER sites. Other ER sites with minor radiological contamination, such as DU, do not produce significant air emission sources from re-suspension.

\section{National Emission Standards for Hazardous Air Pollutants (NESHAP)}

NESHAP, 40 CFR 61, Subpart H, "National Emission Standards for Emissions of Radionuclides Other than Radon from Department of Energy Facilities," has set a maximum of $10 \mathrm{mrem} / \mathrm{yr}$ for all combined air emission pathway sources from any DOE/NNSA facility. Although the dose calculated from the Clean Slate sites is many times less than this standard, there was a question of whether the site would require continuous radiological air monitoring.

The 1995 NESHAP report for TTR reported a calculated effective dose equivalent (EDE) to the maximally exposed individual (MEI) of $1.1 \mathrm{mrem} /$ $\mathrm{yr}$ as a result of diffuse emissions from the Clean Slate sites (SNL 1996). Because the EPA requires continuous air monitoring for any radionuclide source that contributes a dose in excess of 0.1 $\mathrm{mrem} / \mathrm{yr}$ to the MEI, Sandia Corporation instituted continuous air monitoring at the site for one year, from February 22, 1996 to February 25, 1997. The monitoring site was chosen at the TTR Airport, the location of the highest calculated dose for a member

TABLE 4-9. Production Well Monitoring at TTR

\begin{tabular}{|l|l|}
\hline \multicolumn{1}{|c|}{ Analyte } & \multicolumn{1}{|c|}{$\begin{array}{c}\text { Sampling } \\
\text { Frequency }\end{array}$} \\
\hline Total Coliform & Monthly \\
\hline Nitrate, Secondary (13) Drinking Water Standards & 2003 \\
\hline Dioxin,Nitrate, Total Trihalomethanes/Haloacetic Acids (5) & 2004 \\
\hline $\begin{array}{l}\text { Arsenic, IOC's Phase II, IOC's Phase V, Nitrate, Nitrite } \\
\text { Nitrate and Nitrite (Total), SOC's Phase II, SOC's Phase V } \\
\text { Total Trihalomethanes/Haloacetic Acids (5), VOC's Phase I and II, VOC's Phase V, }\end{array}$ & 2005 \\
\hline $\begin{array}{l}\text { Asbestos, Lead/Copper, Nitrate, Secondary (13) Drinking Water Standards } \\
\text { Total Trihalomethanes/Haloacetic Acids (5) }\end{array}$ & 2006 \\
\hline Dioxin, Nitrate & 2007 \\
\hline $\begin{array}{l}\text { Arsenic, IOC's Phase II, IOC's Phase V, Nitrate, Nitrite, Nitrate and Nitrite (Total) } \\
\text { SOC's Phase II, SOC's Phase V, VOC's Phase I and II, VOC's Phase V }\end{array}$ & 2008 \\
\hline Lead/Copper, Nitrate, Secondary (13) Drinking Water Standards & 2009 \\
\hline Dioxin, Nitrate & 2010 \\
\hline NOTE: IOC = inorganic compounds & \\
\hline VOC = volatile organic compounds & \\
\hline SOC $=$ synthetic organic compounds & \\
\hline
\end{tabular}


TABLE 4-10. Calculated Dose Assessment Results for On-site Receptor

\begin{tabular}{|c|c|c|c|c|}
\hline $\begin{array}{l}\text { Dose to } \\
\text { Receptor }\end{array}$ & Location & $\begin{array}{c}1997 \text { Measured } \\
\text { Dose* }^{*}\end{array}$ & $\begin{array}{l}\text { NESHAP } \\
\text { Standard }\end{array}$ & $\begin{array}{c}\text { Natural Back- } \\
\text { ground }\end{array}$ \\
\hline $\begin{array}{l}\text { On-site Receptor } \\
\text { (EDE to the MEI) }\end{array}$ & Airport TTR Area & $\begin{array}{l}0.024 \mathrm{mrem} / \mathrm{yr} \\
(0.00024 \mathrm{mSv} / \mathrm{yr})\end{array}$ & $\begin{array}{l}10 \mathrm{mrem} / \mathrm{yr} \\
(0.1 \mathrm{mSv} / \mathrm{yr})\end{array}$ & $250 \mathrm{mrem} / \mathrm{yr}^{1}$ \\
\hline $\begin{array}{ll}\text { NOTE: } & \text { *Dose calcu } \\
& \mathrm{EDE}=\mathrm{effe} \\
\mathrm{MEI}=\mathrm{max} \\
\mathrm{mrem} / \mathrm{yr}=1 \\
\mathrm{mSv} / \mathrm{yr}=\mathrm{m} \\
\mathrm{TTR}=\mathrm{Ton}\end{array}$ & $\begin{array}{l}\mathrm{d} \text { from continuous mo } \\
\text { dose equivalent } \\
\text { ly exposed individual } \\
\text { rem per year } \\
\text { ievert per year } \\
\text { Test Range }\end{array}$ & oring February 1996 to & dary 1997. & \\
\hline
\end{tabular}

of the public. This site selection is discussed in the 1996 NESHAP report (SNL 1997). The dose assessment result from the continuous monitoring was $0.024 \mathrm{mrem} / \mathrm{yr}$. This was about four times less than the $0.1 \mathrm{mrem} / \mathrm{yr}$ threshold cutoff for which continuous monitoring would be required by the EPA. The average air concentration in curies per cubic meter $\left(\mathrm{Ci} / \mathrm{m}^{3}\right)$ were measured as follows:
Am-241
$4.1 \times 10^{-18} \mathrm{Ci} / \mathrm{m}^{3}$
$\mathrm{Pu}-238$
$1.6 \times 10^{-18} \mathrm{Ci} / \mathrm{m}^{3}$
$\mathrm{Pu}-239 / 240$
$9.5 \times 10^{-19} \mathrm{Ci} / \mathrm{m}^{3}$

Although an annual calculated dose assessment is not required for the site, Sandia Corporation continues to produce an annual NESHAP report for TTR (SNL 2005). The results from the 1996 to 1997 monitoring will continue to be used for as long as there is no change in the status of the Clean Slate sites. Table 4-10 summarizes these dose assessment results. Future TTR activities are not expected to change; however, if new sources or modifications to the existing sources are anticipated, they will be evaluated for NESHAP applicability.

\subsection{NON-RADIOLOGICAL AIR EMISSIONS}

The TTR Class II Air Quality Operating Permit Renewal in 2002 exempted most emission sources used at TTR with the exception of the screening plant and portable screen. In 2004, the total emissions reported to the State of Nevada were 0.002 ton per year from the portable screen. The screening plant was not used. 
chapter five

\section{ANNUAL SITE}

\section{ENVIRONMENTAL REPORT}

\section{FOR THE KAUAI TEST FACILITY}

\section{$\underline{\text { In This Chapter ... }}$}

Facilities and Operations

2004 Rocket Launches

Demographics

Compliance Summary

Environmental Program Activities

Environmental Surveillance \&

Monitoring Activities

Environmental Snapshot

The Sandia National

Laboratories, Kauai Test

Facility (SNL/KTF) has been an active rocket-launching facility since 1962. The site is primarily used for testing rocket systems. Nuclear devices have never been launched from $S N L / K T F$, nor have radiological materials been used at SNL/KTF.
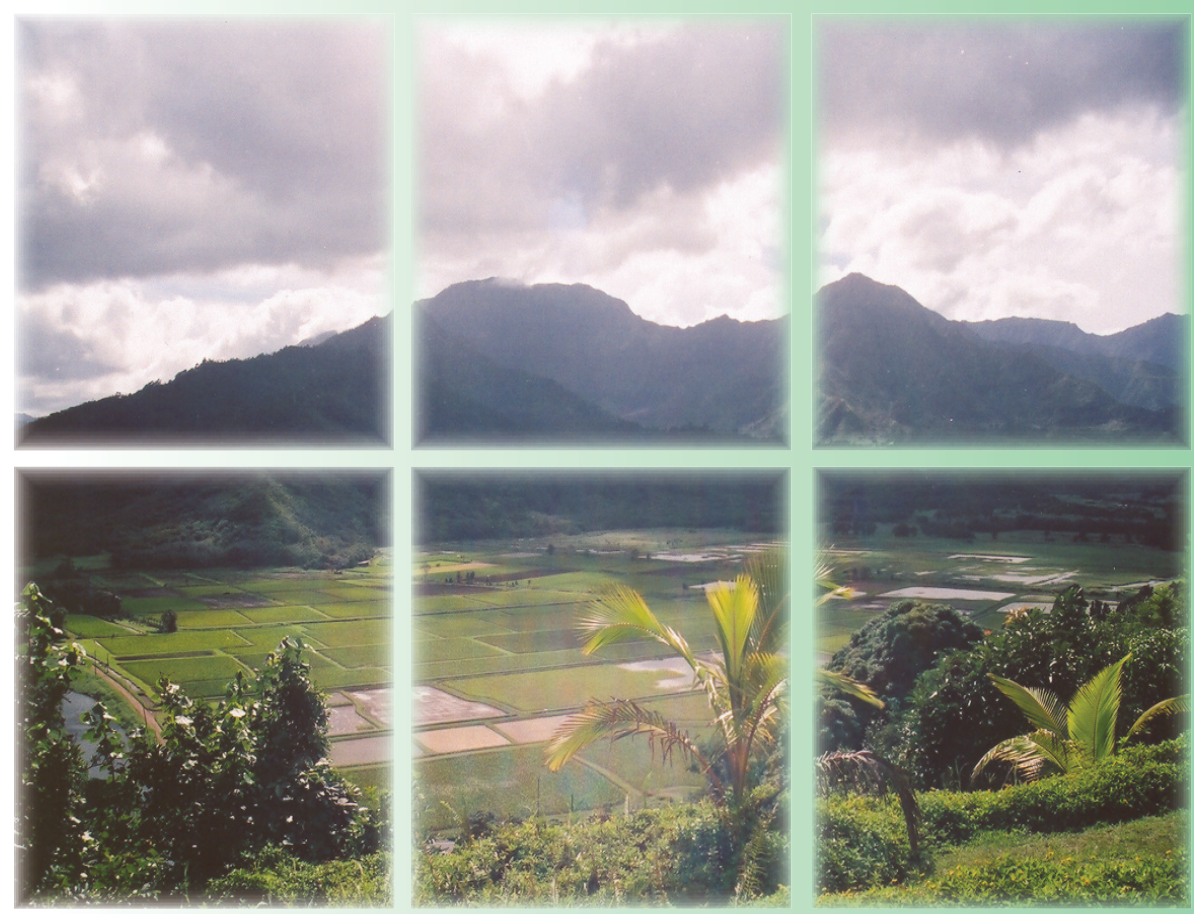

Mountain Range in Kauai 


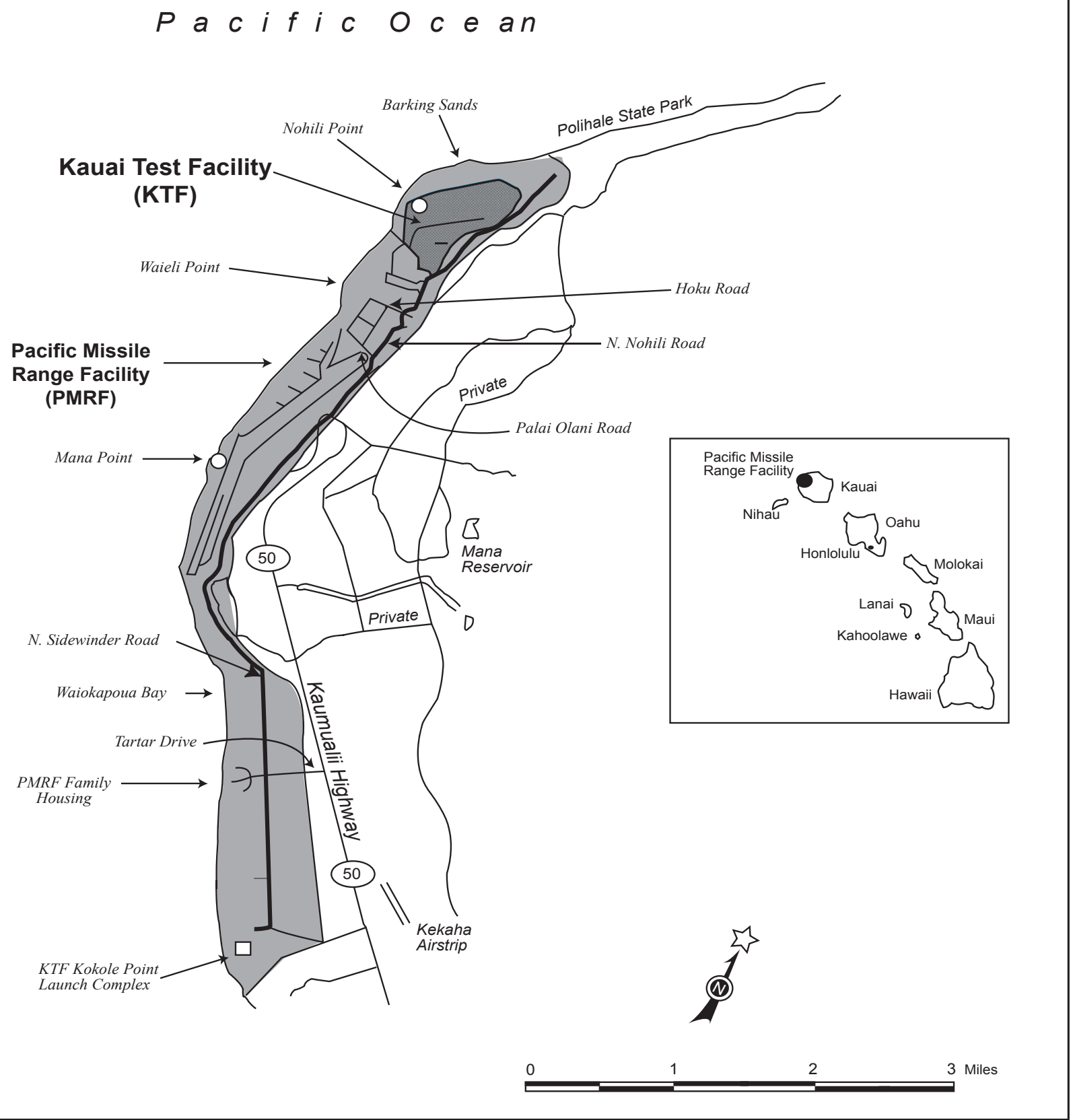

FIGURE 5-1. Map of the Pacific Missile Range Facility (PMRF) and the Adjacent Area (The Kauai Test Facility (KTF) is to the north, near Nohili Point) 
The Kauai Test Facility (KTF) is operated by Sandia Corporation as a rocket preparation, launching, and tracking facility for the U.S. Department of Energy (DOE), National Nuclear Security Administration (NNSA), as well as in support of other U.S. military agencies. Sandia National Laboratories, Kauai Test Facility (SNL/KTF) refers to the facilities at KTF. $\mathrm{SNL} / \mathrm{KTF}$ is owned by the DOE/NNSA and managed by the Sandia Site Office (SSO) in Albuquerque, New Mexico. SNL/KTF exists as a facility within the boundaries of the U.S. Department of Defense (DoD) Pacific Missile Range Facility (PMRF). SNL/KTF is located on the island of Kauai at the north end of the PMRF, near Nohili Point (Figure 5-1). This Annual Site Environmental Report (ASER) summarizes data and the compliance status of the environmental protection and monitoring programs at SNL/KTF for calendar year (CY) 2004. This report was prepared in accordance with DOE Order 450.1, Environmental Protection Program (DOE 2005) and DOE Order 231.1A, Environment, Safety, and Health Reporting (DOE 2004b).

\subsection{FACILITIES AND OPERATIONS}

SNL/KTF has been an active rocket-launching facility since 1962. The KTF and Remote Range Interfaces Department, under Sandia Corporation, manages and conducts the rocket-launching activities at SNL/KTF. The site is primarily used for testing rocket systems with scientific and technological payloads, advanced development of maneuvering re-entry vehicles, scientific studies of atmospheric and exoatmospheric phenomena, and Missile Defense Agency programs. Nuclear devices have never been launched from $\mathrm{SNL} / \mathrm{KTF}$, nor have radiological materials been used at $\mathrm{SNL} / \mathrm{KTF}$.

The first facilities at KTF were constructed in the early 1960s to support the National Readiness Program. The most recent construction, completed in 1994, added four buildings to support DOE and Strategic Defense Initiative (SDI) launches. From 1992 to 2004, there have been 20 launches.

The KTF launcher field was originally designed to accommodate 40 launch pads, but only 15 pads were constructed. Of these, 11 have had their launchers removed. Beyond the implementation of portions of the original plan, two additional launch pads were constructed: Pad 41 at Kokole Point, and Pad 42, the Strategic Targeting System (STARS) launch pad. The launcher field site has a number of permanent facilities used to support rocket operations. In addition to rocket launch pad sites, SNL/KTF facilities include missile assembly areas, data acquisition and operations facilities, a maintenance shop, and a trailer compound for administration and technical support personnel. Other features at SNL/KTF include extensive radar tracking and worldwide radio communication access to other DoD facilities.

The administrative area of SNL/KTF, known as the Main Compound, is located within a fenced area near the North Nohili access road from PMRF. Inside the fenced compound, a number of trailers and vans are connected together with a network of concrete docks and covered walkways. The majority of these temporary facilities are used during operational periods to support the field staff at SNL/KTF. During nonoperational periods, general maintenance continues and dehumidifiers remain in operation (to protect equipment). Additionally, there are a number of permanent buildings, most of which are in use yearround to support and maintain SNL/KTF facilities.

\subsection{ROCKET LAUNCHES}

There were no rockets launched from SNL/KTF in 2004.

\subsection{DEMOGRAPHICS}

There are 13 permanent on-site personnel at SNL/ KTF. During operational periods when rocket launches occur, an additional 15 to 130 persons from the U.S. mainland are brought to SNL/KTF (DOE 1992a). The closest population center to SNL/KTF is the town of Kekaha (population 3,300), which is eight miles from the site.

\subsection{COMPLIANCE SUMMARY}

The list of statutes on page 5-5 provides an overview of compliance status for Sandia Corporation's operations at SNL/KTF in 2004. Table 5-1 lists the applicable permits in place at SNL/KTF.

\section{Comprehensive Environmental Response,} Compensation, and Liability Act (CERCLA)

CERCLA, also known as "Superfund," addresses areas of past spills and releases. SNL/KTF has no 
TABLE 5-1. Permits in Place at SNL/KTF

\begin{tabular}{|l|l|l|l|l|}
\hline \multicolumn{1}{|c|}{ Type } & \multicolumn{1}{|c|}{$\begin{array}{c}\text { Permit } \\
\text { Number }\end{array}$} & $\begin{array}{c}\text { Date } \\
\text { Issued }\end{array}$ & $\begin{array}{c}\text { Expiration } \\
\text { Date }\end{array}$ & \multicolumn{1}{c|}{$\begin{array}{c}\text { Regulatory } \\
\text { Agency }\end{array}$} \\
\hline $\begin{array}{l}\text { Non-covered Source Permit (NSP) } \\
\text { (two stand-by diesel generators) }\end{array}$ & NSP 0429-01-N & April 30, 2004 & April 29, 2009 & State of Hawaii \\
\hline $\begin{array}{l}\text { Resource Conservation and Recovery } \\
\text { Act (RCRA) }\end{array}$ & HI-0000-363309 & Sept. 23, 1994 & Not specified & $\begin{array}{l}\text { EPA Region IX } \\
\text { and Hawaii Dept. } \\
\text { of Health }\end{array}$ \\
\hline $\begin{array}{l}\text { UST (2,500) } \\
\text { NOTE: In 1999, there was a change in reporting fuel through put from annual reporting to biannual reporting to the State of Hawaii. } \\
\text { SNL/KTF = Sandia National Laboratories, Kauai Test Facility }\end{array}$ & $\begin{array}{l}\text { EPA Region IX } \\
\text { and Hawaii Dept. } \\
\text { of Health }\end{array}$ \\
$\begin{array}{l}\text { EPA = U.S. Environmental Protection Agency } \\
\text { UST = Underground Storage Tank }\end{array}$ & Not applicable & Sept. 13, 1991 & Indefinite &
\end{tabular}

current Environmental Restoration (ER) areas located on-site.

The U.S. Environmental Protection Agency (EPA) designated ongoing oversight of SNL/KTF to the Hawaii Department of Health Hazard Evaluation and Emergency Response Office. The EPA recommended continued reevaluation for environmental contamination due to the launching facility. Rocket exhaust continues to be the main source of metals and other non-reportable air emission releases.

\section{Superfund Amendments and Reauthorization Act (SARA)}

SARA Title III requires chemical inventory information and threshold quantity reporting as directed by the Emergency Planning and Community Right-to-Know Act (EPCRA), Sections 311 and 312. All required information has been submitted to the State of Hawaii. There were no reportable releases at SNL/KTF under EPCRA or CERCLA in 2004. Table 5-2 lists SARA Title III reporting requirements.

\section{Resource Conservation and Recovery Act (RCRA)}

In 1994, SNL/KTF reached "small quantity hazardous waste generator" status as defined by RCRA, and therefore, obtained an EPA Identification Number. However, the volume of waste generated in 2004 qualified SNL/KTF to maintain "conditionally exempt small quantity generator" status.

\section{Federal Facility Compliance Act (FFCA)}

The FFCA addresses the disposition of mixed waste (MW) at federal facilities. No radioactive waste of any kind has been generated or stored at SNL/KTF and, therefore, this statute is not applicable to the site.

\section{National Environmental Policy Act (NEPA)}

NEPA requires federal agencies and private entities that perform federally-sponsored projects to include environmental aspects in early project planning and decision-making. A major intent of the law is to ensure that federal agencies are aware of the potential environmental impacts associated with their operations and include this information in early project planning and decision-making. NEPA mandates that an agency's decision process be open for public review. Additionally, if a proposed action is determined to have environmentally "significant" impacts, the agency must prepare an EA or an environmental impact statement (EIS) before an irretrievable commitment of resources or funding occurs. Although a major objective of NEPA is to preserve the environment for future generations, the law does not require an agency to select the proposed action alternative with the least environmental impacts. The DOE/NNSA/SSO coordinates NEPA compliance at SNL/KTF with Sandia National Labs, New Mexico (SNL/NM).

\section{Endangered Species Act (ESA)}

The ESA applies to both private individuals and federal agencies. Federal agencies must ensure that any action authorized, funded, or carried out by them will not jeopardize the continued existence of a threatened or endangered species, or result in adverse modifications of its habitat. The ESA is addressed under the NEPA Program and Ecology Program. If potentially significant impacts to sensitive species or habitats are found as a result of the proposed action, an EA or an EIS must be prepared.

Table 5-3 lists all threatened and endangered state and federal listed species occurring on the island of Kauai. 


\section{Major Environmental Regulations \& Statutes Applicable to KTF}

\section{Clean Air Act (CAA) and CAA Amendments (CAAA)}

Provides standards to protect the nation's air quality http://www.epa.gov/oar/oaq_caa.html

\section{Clean Water Act (CWA)}

Provides general water quality standards to protect the nation's water sources and byways http://www.epa.gov/region5/watercwa.htm

\section{Comprehensive Environmental Response, Compensation, and Liability Act (CERCLA)} Provides federal funding for cleanup of inactive waste sites on the National Priorities List (NPL) and mandates requirements for reportable releases of hazardous substances $\mathrm{http}: / \mathrm{www} . \mathrm{epa.gov} / \mathrm{region} 5 / \mathrm{defs} / \mathrm{html} / \mathrm{cercla} . \mathrm{htm}$

\section{Cultural resources acts}

Includes various acts that protect archeological, historical, religious sites, and resources http://water.usgs.gov/eap/env_guide/cultural.html

\section{Endangered Species Act (ESA)}

Provides special protection status for federally-listed endangered or threatened species http://www.epa.gov/region5/defs/html/esa.htm

\section{Executive Orders (EOs)}

Several EOs provide specific protection for wetlands, floodplains, environmental justice in minority and low-income populations, and greening the government through leadership in environmental management http://www.archives.gov/federal_register/executive_orders/disposition_tables.html

\section{Federal Facility Compliance Act (FFCA)}

Directs federal agencies regarding environmental compliance http://tis.eh.doe.gov/oepa/laws/ffca.html

\section{Federal Insecticide, Fungicide, and Rodenticide Act (FIFRA)}

Controls the distribution and use of various pesticides http://www.epa.gov/region $5 / \mathrm{defs} / \mathrm{html} / \mathrm{fifra}$.htm

\section{Migratory Bird Treaty Act (MBTA) of 1918}

Prevents the taking, killing, possession, transportation and importation of migratory birds, their eggs, parts, and nests http://tis.eh.doe.gov/oepa/laws/mbta.html

\section{National Emission Standards for Hazardous Air Pollutants (NESHAP)}

Specifies standards for radionuclide air emissions and other hazardous air releases under the CAA http://www.epa.gov/radiation/neshaps/

\section{National Environmental Policy Act (NEPA)}

Requires federal agencies to review all proposed activities so as to include environmental aspects in agency decision-making http://tis.eh.doe.gov/NEPA/

\section{Resource Conservation and Recovery Act (RCRA)}

Mandates the management of solid and hazardous waste and certain materials stored in underground storage tanks (USTs) http://www.epa.gov/region5/defs/html/rcra.htm

\section{Safe Drinking Water Act (SDWA)}

Provides specific standards used for drinking water sources $\mathrm{http} / /$ www.epa.gov/safewater/sdwa/sdwa.html

\section{Superfund Amendments and Reauthorization Act (SARA)}

SARA,Title III, also known as the Emergency Planning and Community-Right-to-Know Act (EPCRA), mandates communication standards for hazardous materials over a threshold amount that are stored or used in a community http://www.epa.gov/region5/defs/html/sara.htm

\section{Toxic Substance Control Act (TSCA)}

Specifies rules for the manufacture, distribution, and disposal of specific toxic materials such as asbestos and polychlorinated biphenyls (PCBs) http://www.epa.gov/compliance/civil/tsca/index.html 
TABLE 5-2. 2004 SARA Title III (or EPCRA) Reporting Requirements Applicable to SNL/KTF

\begin{tabular}{|c|c|c|c|c|}
\hline \multirow[b]{2}{*}{ Section } & \multirow{2}{*}{$\begin{array}{l}\text { SARA Title III } \\
\text { Section Title }\end{array}$} & \multicolumn{2}{|c|}{ Requires Reporting? } & \multirow[b]{2}{*}{ Description } \\
\hline & & Yes & No & \\
\hline $302-303$ & $\begin{array}{l}\text { Notification/ } \\
\text { Plans }\end{array}$ & $\checkmark$ & & $\begin{array}{l}\text { Sandia Corporation submits an annual report } \\
\text { listing chemical inventories above the reportable } \\
\text { Threshold Planning Quantities listed in } 40 \text { CFR } \\
\text { Part } 355 \text { Appendix B, location of the chemicals } \\
\text { and emergency contacts. The report is prepared for } \\
\text { the DOE/NNSA/SSO, which distributes it to the } \\
\text { required entities. }\end{array}$ \\
\hline 304 & $\begin{array}{l}\text { Emergency } \\
\text { Notification }\end{array}$ & & $\checkmark$ & $\begin{array}{l}\text { No RQ releases of an EHS, or as defined under } \\
\text { CERCLA, occurred in } 2004 \text {. }\end{array}$ \\
\hline 311-312 & $\begin{array}{l}\text { MSDSs/ } \\
\text { Chemical } \\
\text { Purchase } \\
\text { Inventory Report }\end{array}$ & $\checkmark$ & & $\begin{array}{l}\text { There are two "Community Right-to-Know" } \\
\text { reporting requirements: (a) SNL/KTF completes } \\
\text { the EPA Tier II forms for all hazardous chemicals } \\
\text { present at the facility at any one time in amounts } \\
\text { equal to or greater than } 10,000 \mathrm{lbs} \text { and for all } \\
\text { EHSs present at the facility in an amount greater } \\
\text { than or equal to } 500 \mathrm{lbs} \text { or the Threshold Planning } \\
\text { Quantity, whichever is lower; (b) SNL/KTF } \\
\text { provides MSDSs for each chemical entry on a Tier } \\
\text { II form unless it decides to comply with the EPA's } \\
\text { alternative MSDS reporting, which is detailed in } 40 \\
\text { CFR Part } 370.21 \text {. }\end{array}$ \\
\hline 313 & $\begin{array}{l}\text { Toxic Chemical } \\
\text { Release Forms }\end{array}$ & & $\checkmark$ & $\begin{array}{l}\text { Sandia Corporation is below the reporting } \\
\text { threshold in } 2004 \text { for producing a TRI Report for } \\
\text { SNL/KTF operations. }\end{array}$ \\
\hline
\end{tabular}

NOTE: MSDS = Material Safety Data Sheets (gives relevant chemical information)

EHS $=$ extremely hazardous substance $\quad$ TRI $=$ Toxic Release Inventory

$\mathrm{RQ}=$ reportable quantity $\quad \mathrm{SNL} / \mathrm{KTF}=$ Sandia National Laboratories, Kauai Test Facility

$\mathrm{EPA}=\mathrm{U} . \mathrm{S}$. Environmental Protection Agency

DOE/NNSA/SSO = U.S. Department of Energy, National Nuclear Security Administration, Sandia Site Office

CERCLA = Comprehensive Environmental Response, Compensation, and Liability Act

SARA $=$ Superfund Amendments and Reauthorization Act

EPCRA $=$ Emergency Planning and Community Right-to-Know Act

\section{Cultural Resources Acts}

The three primary cultural resources acts applicable at SNL/KTF are as follows:

- National Historic Preservation Act (NHPA);

- Archaeological Resources Protection Act(ARPA); and

- American Indian Religious Freedom Act (AIRFA).

At $\mathrm{SNL} / \mathrm{KTF}$, cultural resources compliance is coordinated through the NEPA Program. Actions that could adversely affect cultural resources are initially analyzed in a NEPA Checklist.

\section{Migratory Bird Treaty Act (MBTA) of 1918}

The MBTA of 1918 implemented the 1916 Convention for the protection of migratory birds. The original statute implemented the agreement between the United States (U.S.) and Great Britain (for Canada) and later amendments implemented treaties between the U.S. and
Mexico, the U.S. and Japan, and the U.S. and Russia. In addition to the special consideration afforded to species listed as threatened and endangered, most birds are protected under the MBTA of 1918, as amended. At SNL/KTF, the MBTA is coordinated with NEPA compliance reviews and the Ecology Program.

\section{Environmental Compliance Executive Orders (EOs)}

The four primary EOs related to environmental compliance at SNL/KTF are as follows:

- $\quad$ EO 11990, Protection of Wetlands, as amended

- EO 11988, Floodplain Management, as amended

- EO 12898, Federal Actions to Address Environmental Justice in Minority Populations and Low-Income Populations, as amended 
TABLE 5-3. Threatened and Endangered Species Potentially Occurring on SNL/KTF

\begin{tabular}{|c|c|c|c|}
\hline $\begin{array}{l}\text { Common Name } \\
\text { Plants }\end{array}$ & Scientific Name & $\begin{array}{c}\text { Federal } \\
\text { Status }\end{array}$ & State Status \\
\hline Liliwai & Acaena exigua & Endangered & Endangered \\
\hline No common name & Achyranthes mutica & Endangered & Endangered \\
\hline Mahoe & Alectryon macrococcus & Endangered & Endangered \\
\hline Kuawawaenohu & Alsinidendron lychnoides & Endangered & Endangered \\
\hline No common name & Alsinidendron viscosum & Endangered & Endangered \\
\hline No common name & Bonamia menziesii & Endangered & Endangered \\
\hline Olulu & Brighamia insignis & Endangered & Endangered \\
\hline Uhiuhi & Caesalpinia kavaiense & Endangered & Endangered \\
\hline 'Awiwi & Centaurium sebaeoides & Endangered & Endangered \\
\hline No common name & Chamaesyce halemanui & Endangered & Endangered \\
\hline Pauoa & Ctenitis squamigera & Endangered & Endangered \\
\hline Haha & Cyanea asarifolia & Endangered & Endangered \\
\hline Haha & Cyanea recta & Threatened & Threatened \\
\hline Haha & Cyanea remyi & Endangered & Endangered \\
\hline Haha & Cyanea undulata & Endangered & Endangered \\
\hline Pu'uka'a & Cyperus trachysanthos & Endangered & Endangered \\
\hline Ha'iwale & Cyrtandra limahuliensis & Threatened & Threatened \\
\hline Mapele & Cyrtandra cyaneoides & Endangered & Endangered \\
\hline No common name & Delissea rhytidosperma & Endangered & Endangered \\
\hline 'Oha & Delissea rivularis & Endangered & Endangered \\
\hline $\begin{array}{l}\text { Asplenium Leaved } \\
\text { Diella }\end{array}$ & Diellia erecta & Endangered & Endangered \\
\hline No common name & Diellia pallida & Endangered & Endangered \\
\hline No common name & Diplazium molokaiense & Endangered & Endangered \\
\hline Na'ena'e & Dubautia pauciflorula & Endangered & Endangered \\
\hline Na'ena'e & Dubautia latifolia & Endangered & Endangered \\
\hline 'Akoko & Euphorbia haeleeleana & Endangered & Endangered \\
\hline Heau & Exocarpos luteolus & Endangered & Endangered \\
\hline Mehamehame & Flueggea neowawraea & Endangered & Endangered \\
\hline No common name & Gouania meyenii & Endangered & Endangered \\
\hline Honohono & Haplostachys haplostachya & Endangered & Endangered \\
\hline 'Awiwi & Hedyotis cookiana & Endangered & Endangered \\
\hline $\begin{array}{l}\text { Na Pali Beach } \\
\text { Hedvotis }\end{array}$ & Hedyotis st.-johnii & Endangered & Endangered \\
\hline No common name & Hesperomannia lydgatei & Endangered & Endangered \\
\hline Kauai Hau Kuahiwi & Hibiscadelphus distans & Endangered & Endangered \\
\hline Hau Kuahiwi & Hibiscadelphus woodii & Endangered & Endangered \\
\hline Hibiscus, Clay’s & Hibiscus clayi & Endangered & Endangered \\
\hline Koki'o ke'oke'o & Hibiscus waimeae ssp. hannerae & Endangered & Endangered \\
\hline Wawae'iole & $\begin{array}{l}\text { Huperzia mannii (Phlegmariurus } \\
\text { mannii) }\end{array}$ & Endangered & Endangered \\
\hline Ischaemum, Hilo & Ischaemum byrone & Endangered & Endangered \\
\hline Aupaka & Isodendrion laurifolium & Endangered & Endangered \\
\hline Aupaka & Isodendrion longifolium & Threatened & Threatened \\
\hline Koki’o & Kokia kauaiensis & Endangered & Endangered \\
\hline
\end{tabular}


TABLE 5-3. Threatened and Endangered Species Potentially Occurring on SNL/KTF (continued)

\begin{tabular}{|c|c|c|c|}
\hline Common Name & Scientific Name & $\begin{array}{l}\text { Federal } \\
\text { Status }\end{array}$ & State Status \\
\hline Kamakahala & Labordia lydgatei & Endangered & Endangered \\
\hline Kamakahala & Labordia tinifolia var. wahiawaensis & Endangered & Endangered \\
\hline Nehe & Lipochaeta fauriei & Endangered & Endangered \\
\hline Nehe & Lipochaeta micrantha & Endangered & Endangered \\
\hline Nehe & Lipochaeta waimeaensis & Endangered & Endangered \\
\hline Wawae'iole & $\begin{array}{l}\text { Lycopodium nutans (Phlegmariurus } \\
\text { nutans) }\end{array}$ & Endangered & Endangered \\
\hline No common name & Lysimachia filifolia & Endangered & Endangered \\
\hline No common name & Mariscus pennatiformis ssp. pennatiformis & Endangered & Endangered \\
\hline Alani & Melicope haupuensis & Endangered & Endangered \\
\hline Alani & Melicope knudsenii & Endangered & Endangered \\
\hline Alani & Melicope pallida & Endangered & Endangered \\
\hline Alani & Melicope quadrangularis & Endangered & Endangered \\
\hline No common name & Munroidendron racemosum & Endangered & Endangered \\
\hline Kolea & Myrsine linearifolia & Threatened & Threatened \\
\hline 'Aiea & Nothocestrum peltatum & Endangered & Endangered \\
\hline Lau 'ehu & Panicum niihauense & Endangered & Endangered \\
\hline Makou & Peucedanum sandwicense & Threatened & Threatened \\
\hline No common name & Phyllostegia glabra var. lanaiensis & Endangered & Endangered \\
\hline No common name & Phyllostegia knudsenii & Endangered & Endangered \\
\hline No common name & Phyllostegia waimeae & Endangered & Endangered \\
\hline No common name & Phyllostegia wawrana & Endangered & Endangered \\
\hline No common name & Platanthera holochila & Endangered & Endangered \\
\hline Mann's Bluegrass & Poa mannii & Endangered & Endangered \\
\hline Hawaiian Bluegrass & Poa sandvicensis & Endangered & Endangered \\
\hline No common name & Poa siphonoglossa & Endangered & Endangered \\
\hline Lo'ulu & Pritchardia napaliensis & Endangered & Endangered \\
\hline Lo'ulu & Pritchardia viscosa & Endangered & Endangered \\
\hline Kaulu & Pteralyxia kauaiensis & Endangered & Endangered \\
\hline No common name & Remya kauaiensis & Endangered & Endangered \\
\hline No common name & Remya montgomeryi & Endangered & Endangered \\
\hline Dwarf Naupaka & Scaevola coriacea & Endangered & Endangered \\
\hline Ma'oli'oli & Schiedea apokremnos & Endangered & Endangered \\
\hline No common name & Schiedea helleri & Endangered & Endangered \\
\hline No common name & Schiedea kauaiensis & Endangered & Endangered \\
\hline No common name & Schiedea membranacea & Endangered & Endangered \\
\hline No common name & Schiedea nuttallii & Endangered & Endangered \\
\hline No common name & Schiedea spergulina var. leiopoda & Endangered & Endangered \\
\hline No common name & Schiedea spergulina var. spergulina & Threatened & Threatened \\
\hline Laulihilihi & Schiedea stellarioides & Endangered & Endangered \\
\hline 'Ohai & Sesbania tomentosa & Endangered & Endangered \\
\hline No common name & Silene lanceolata & Endangered & Endangered \\
\hline Popolo Ku Mai & Solanum incompletum & Endangered & Endangered \\
\hline
\end{tabular}


TABLE 5-3. Threatened and Endangered Species Potentially Occurring on SNL/KTF (concluded)

\begin{tabular}{|c|c|c|c|}
\hline Common Name & Scientific Name & Federal Status & State Status \\
\hline Popolo 'aiakeakua & Solanum sandwicense & Endangered & Endangered \\
\hline No common name & Spermolepis hawaiiensis & Endangered & Endangered \\
\hline No common name & Stenogyne campanulata & Endangered & Endangered \\
\hline No common name & Viola helenae & Endangered & Endangered \\
\hline Nani wai'ale'ale & Viola kauaensis var. wahiawaensis & Endangered & Endangered \\
\hline Iliau, Dwarf & Wilkesia hobdyi & Endangered & Endangered \\
\hline No common name & Xylosma crenatum & Endangered & Endangered \\
\hline A'e & Zanthoxylum dipetalum & Endangered & Endangered \\
\hline A'e & Zanthoxylum hawaiiense & Endangered & Endangered \\
\hline \multicolumn{4}{|c|}{ ANIMALS } \\
\hline \multicolumn{4}{|l|}{ Mammals } \\
\hline Hawaiian Hoary Bat & Lasiurus cinereus semotus & Endangered & Endangered \\
\hline Hawaiian Monk Seal & Monachus schauinslandi & Endangered & Endangered \\
\hline \multicolumn{4}{|l|}{ Birds } \\
\hline Hawaiian Duck & Anas wyvilliana & Endangered & Endangered \\
\hline Hawaiian Coot & Fulica americana alai & Endangered & Endangered \\
\hline Hawaiian Gallinule & Gallinula chloropus sandvicensis & Endangered & Endangered \\
\hline Kauai Nuku pu’u & Hemignathus lucidus hanapepe & Endangered & Endangered \\
\hline Kauai 'Akia loa & Hemignathus procerus & Endangered & Endangered \\
\hline Black-necked Stilt & Himantopus mexicanus knudseni & Endangered & Endangered \\
\hline Kauai ‘O’o & Moho braccatus & Endangered & Endangered \\
\hline Large Kauai Thrush & Myadestes myadestinus & Endangered & Endangered \\
\hline Small Kauai Solitare & Myadestes palmeri & Endangered & Endangered \\
\hline Hawaiian Goose & Nesochen sandvicensis & Endangered & Endangered \\
\hline No common name & Psittirostra psittacea & Endangered & Endangered \\
\hline Dark-rumped Petrel & $\begin{array}{l}\text { Pterodroma phaeopygia } \\
\text { sandwichensis }\end{array}$ & Endangered & Endangered \\
\hline Newell's Shearwater & Puffinus auricularis newelli & Threatened & Threatened \\
\hline \multicolumn{4}{|l|}{ Reptiles } \\
\hline $\begin{array}{l}\text { Loggerhead Sea Turtle } \\
\text { (incidental in Hawaii) }\end{array}$ & Caretta caretta & Threatened & Threatened \\
\hline Green Sea Turtle & Chelonia mydas & Threatened & Threatened \\
\hline $\begin{array}{l}\text { Leatherback Sea Turtle } \\
\text { (incidental in Hawaii) }\end{array}$ & Dermochelys coriaceae & Endangered & Endangered \\
\hline Hawksbill Turtle & Eretmochelys imbricata & Endangered & Endangered \\
\hline \multicolumn{4}{|l|}{ Snails } \\
\hline Newcomb's Snail & Erinna newcombi & Threatened & Threatened \\
\hline \multicolumn{4}{|l|}{ Arachnids } \\
\hline $\begin{array}{l}\text { Kauai Cave Wolf } \\
\text { Spider }\end{array}$ & Adelocosa anops & Endangered & Endangered \\
\hline \multicolumn{4}{|l|}{ Insects } \\
\hline $\begin{array}{l}\text { Blackburn's Sphinx } \\
\text { Moth }\end{array}$ & Manduca blackburni & Endangered & Endangered \\
\hline Kauai Pomace Fly & Drosophila musaphila & Proposed Endangered & $\begin{array}{l}\text { Proposed } \\
\text { Endangered }\end{array}$ \\
\hline \multicolumn{4}{|l|}{ Crustaceans } \\
\hline Kauai Cave Amphipod & Spelaeorchestia koloana & Endangered & Endangered \\
\hline
\end{tabular}

\section{KTF ASER}


- $\quad$ EO 13148, Greening the Government Through Leadership in Environmental Management

Clean Air Act (CAA) and Clean Air Act Amendments (CAAA) of 1990

Ambient air quality is regulated by Hawaii Administrative Rules (HAR), Title 11, Chapter 59 under the jurisdiction of the Hawaii Department of Health, Clean Air Branch. Currently, there are no facilities at SNL/KTF that require federal air permits or compliance with the New Source Performance Standards (NSPS), "Prevention of Significant Deterioration (PSD)," or 40 CFR 61, "National Emission Standards for Hazardous Air Pollutants" (NESHAP). Within the boundaries of PMRF, no federal air emission permits are held either by DOE for SNL/KTF, or by DoD for PMRF. However, the two electrical generators at SNL/KTF are permitted for operation by the State of Hawaii under a "Noncovered Source Permit (NSP)" (Hawaii Department of Health 2004).

As required by the EPA, the 2004 Annual Fee and Monitoring Report (air emissions) was submitted to the State of Hawaii at the end of February 2005 (SNL 2005b). In 2004, the total usage reported to the State of Hawaii was 4,736 gallons of diesel fuel. Sandia Corporation was in compliance with all air quality regulations in 2004.

Rocket launches are mobile sources and do not require reporting of reportable quantity (RQ) releases.

\section{Clean Water Act (CWA)}

There were no compliance issues with respect to any state or federal water pollution regulations in 2004. There are three septic tanks on-site owned by SNL/ KTF facilities, which currently do not require permits from the State of Hawaii.

A National Pollutant Discharge Elimination System (NPDES) permit is not required due to the lack of significant storm water runoff discharging into "Waters of the U.S," as defined in 40 CFR 122. However, this is not to say that there is no runoff. The EPA has concern with storm water runoff washing off the launcher pads and discharging to the ocean. Some of the downstream pathways include habitat for several federally-designated endangered or threatened species. The EPA has therefore recommended periodic evaluations for environmental contamination.
Oil Storage - There is one underground storage tank (UST) at SNL/KTF, which is owned by the DOE. There is also one 10,000-gallon above ground fuel tank inside the Main Compound. Sandia Corporation cooperates with the U.S. Navy's spill control guidelines contained in the Spill Prevention Control and Countermeasures (SPCC) Plan, Pacific Missile Range Facility (NFEC 2003).

\section{Safe Drinking Water Act (SDWA)}

The SDWA does not apply directly to Sandia Corporation activities at SNL/KTF because all drinking water is obtained through PMRF's facilities or is purchased from commercial suppliers.

\section{Toxic Substances Control Act (TSCA)}

TSCA regulates the distribution of polychlorinated biphenyls (PCBs) and asbestos. The transformers on the SNL/KTF site have been tested and are free of PCBs, and there are no asbestos issues at the site.

\section{Federal Insecticide, Fungicide, and Rodenticide Act (FIFRA)}

FIFRA controls the distribution and application of pesticides including herbicides, insecticides, and rodenticides. All pesticide use at SNL/KTF follows EPA requirements.

\section{Releases and Occurrences}

There were no reportable occurrences at SNL/KTF in 2004.

\subsection{ENVIRONMENTAL PROGRAM ACTIVITIES}

This section describes three environmental programs: NEPA, the ER Project, and the Spill Prevention Program.

\section{NEPA Program Activities}

In accordance with NEPA, a comprehensive Sitewide EA was completed for SNL/KTF in 1992 (DOE 1992a), which resulted in a Finding of No Significant Impact (FONSI), issued on July 17, 1992. This EA is the current NEPA document covering all rocketlaunching activities at SNL/KTF. Additionally, an EIS specific to the STARS Program is in place for rocket launches of this type (DoD 1998).

Prior to Sandia Corporation beginning any proposed action that may potentially affect sensitive species or habitats, a NEPA Checklist is submitted to DOE/ NNSA/SSO for a determination. As it is applicable, 
DOE/NNSA/SSO must consult with the following agencies:

- U.S. Fish and Wildlife Service

- State of Hawaii Department of Land and Natural Resources

In 2004, SNL/NM NEPA staff completed one NEPA compliance review for proposed actions at SNL/KTF. This review referenced existing NEPA documentation for KTF.

\section{ER Project Activities}

There are no ER sites at SNL/KTF. The three ER sites identified in 1995 were given a No Further Action (NFA) determination by the EPA on September 30, 1996. This confirmed that SNL/KTF met all CERCLA requirements and no additional sampling or remediation would be necessary in the three areas. This, however, does not preclude that other environmental sampling activities will take place at SNL/KTF.

\subsection{ENVIRONMENTAL SURVEILLANCE AND MONITORING ACTIVITIES}

\section{Wastewater Monitoring}

Sandia Corporation's activities at SNL/KTF produce only sanitary sewage, which is directed into five wastewater systems - three septic tanks and two French drains - in accordance with Hawaii Underground Injection Control regulations (HAR Title 11, Chapter 23). The septic systems are periodically pumped by licensed state-certified contractors and inspected by state officials. The limited quantity of sewage released does not impact any protected waters and, as noted earlier, there are no drinking water wells in the area of SNL/KTF. Currently, septic tanks do not require permitting or sampling. As a best management practice (BMP), Sandia Corporation periodically performs sampling. No contaminants were identified above the reporting limits from past sampling events.

\section{Air Emission Monitoring}

Based on effluent air monitoring results of the STARS Flight Test Unit 1 (FTU-1) in February 1993 and the CDX rocket launch in the summer of 1992 (SNL 1992), it was determined that rocket launches at SNL/ KTF were not a significant source of air pollutants. Launches are infrequent and emissions recorded did not exceed federal and state standards. Because the STARS type rocket produces the greatest air emissions and remained within acceptable limits, it can be assumed that future launches of this type will also be within acceptable limits. Therefore, no further air emission monitoring is planned at this time. If a new rocket type is launched from SNL/KTF that differs in emission substance from the STARS rocket, or air emission requirements change, future monitoring may be considered.

\section{Meteorological Monitoring}

On-site meteorological instruments are used during test periods to characterize atmospheric transport, diffusion conditions, and stability classes. Due to the infrequency of launches, no formal meteorological monitoring plan is in place for SNL/KTF. Climatic information representative of SNL/KTF is obtained from the PMRF.

\section{Noise Monitoring}

In accordance with the Quiet Communities Act of 1978 (42 U.S.C. 4901 et seq.), noise monitoring was conducted in February 1993 during the STARS FTU-1 launch to confirm the determination made in the STARS EIS that noise produced from the largest launch would be below maximum acceptable levels (SNL 1993). Data collected in the nearest town of Kekaha indicated that levels were no louder than noise generated from passing vehicles on a nearby highway.

\section{Terrestrial Surveillance}

Terrestrial surveillance sampling of soil is conducted every five years. No sampling occurred in 2004.

\section{KTF ASER}


This page intentionally left blank. 


\section{chapter six}

\section{TTR \& KTF REFERENCES}

In This Chapter ...

References

Executive Orders

DOE Orders

Code of Federal

Regulations

Act and Statutes

State of Hawaii

Environmental Regulations

State of Nevada

Environmental Regulations
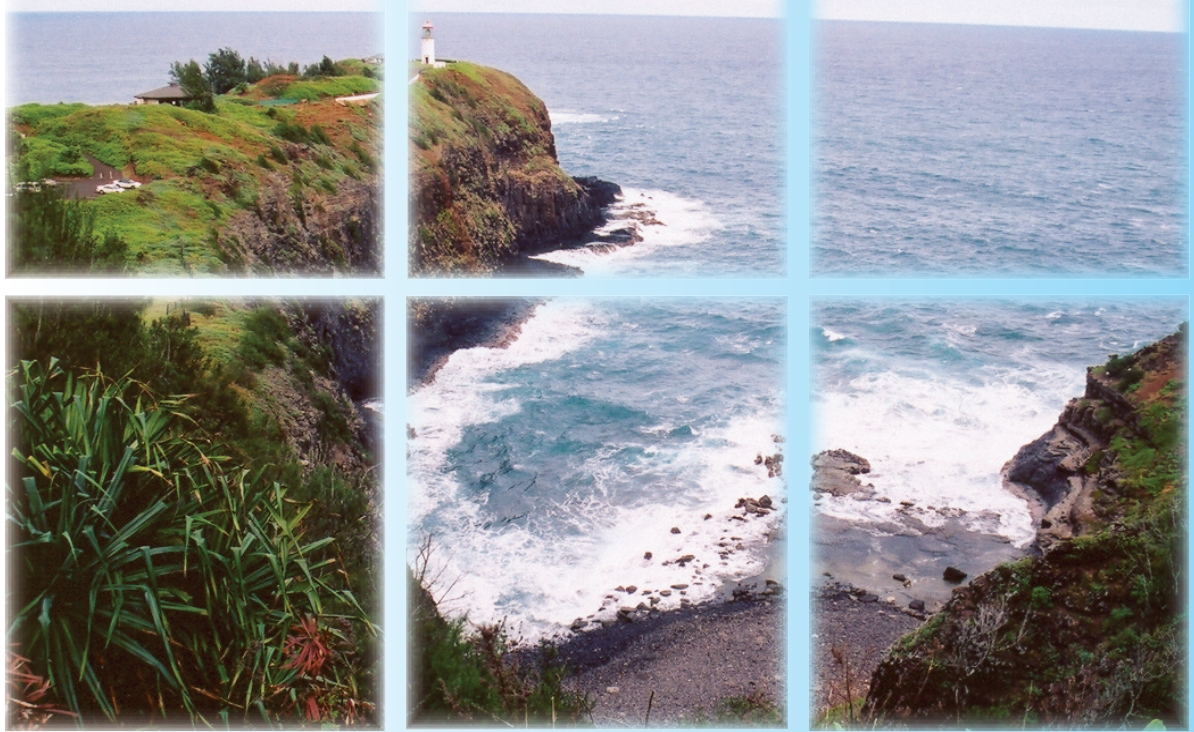
ASI 1990 Archaeological Survey and Testing, Department of Energy, Kauai Test Facility. Prepared for Sandia National Laboratories, by Advanced Sciences, Inc., San Diego, CA (1990).

Brock 1990 Brock, Richard E., A Survey of the Green Sea Turtle Population Fronting the Kauai Test Facility, Pacific Missile Range, Barking Sands, Kauai: An Analysis of Potential Impacts with Implementation of the Strategic Defense Initiative. Prepared for IT Corporation by Environmental Assessment Co., Honolulu, HI (1990).

Brookins 1992 Brookins, D., "Background Radiation in the Albuquerque, New Mexico, U.S.A., Area," in Environmental Geology and Water Science, Vol. 19, No. 1, pp. 11-15 (1992).

DOC 2005 U.S. Department of Commerce, U.S. Census Bureau, website at $<\underline{\text { http: } / / \text { www.census.gov } />}$ Washington, DC (2005).

DoD 1998 U.S. Department of Defense, Pacific Missile Range Facility Enhanced Capability Final Environmental Impact Statement (EIS). U.S. Department of Defense, Department of the Navy, Kauai, HI (December 1998).

DoD/DOE/ State of NV 1996

DOE 2005

DOE 2004

DOE 2004a

DOE 2004b

DOE 2003

DOE 2002

DOE 2001

DOE 2001a

DOE 1996

DOE 1994

DOE 1993

DOE 1993a

DOE 1992
U.S. Department of Defense, U.S. Department of Energy, and Nevada Department of Conservation and Natural Resources, Federal Facility Agreement and Consent Order (FFACO). State of Nevada Department of Conservation and Natural Resources, Division of Environmental Protection and the U.S. DOE and the U.S DoD in the Matter of Federal Facility Agreement and Consent Order (March 15, 1996). Available on the Web at: http://ndep.nv.gov/boff/ffco.htm.

DOE Order 450.1 (See DOE Orders Section).

U.S. Department of Energy, Nevada Test Site Environmental Report 2003, DOE/NV 11718-971. Prepared by Bechtel for the U.S. DOE/NNSA, Las Vegas NV (2004).

DOE Manual 231.1-1A (See DOE Orders Section).

DOE Order 231.1A (See DOE Orders Section).

DOE Order 231.1-2 (see DOE Orders Section).

DOE Order 470.2B (See DOE Orders Section).

DOE Order 451.1B (See DOE Orders Section).

DOE Order 435.1 (See DOE Orders Section).

U.S. Department of Energy, Final Environmental Impact Statement for the Nevada Test Site and Off-Site Locations in the State of Nevada, DOE/EIS-0243. DOE, Nevada Operations Office, Las Vegas, NV (August 1996).

U.S. Department of Energy, Memorandum of Agreement Between the Nevada Operations Office and the Albuquerque Operations Office, DE-GM08-98NV13555, as amended (Appendix C, Tonopah Test Range, signed October 1997). U.S. Department of Energy, Albuquerque, NM and Las Vegas, NV (1994).

DOE Order 5400.5 (See DOE Orders Section).

DOE/AL Order 5400.2A (See DOE Orders Section).

U.S. Department of Energy, Water Conservation Plan for the Tonopah Test Range, Range 4809. U.S. Department of Energy/Nevada Operations Office, Las Vegas, NV (1992). 
DOE 1992a

Dragun and

Chekiri

2005

DRI/DOE 2005 Desert Research Institute/U. S. Department of Energy, Community Environmental Monitoring Program ( CEMP) website: http://www.wrcc.dri.edu/cemp/ (2005).

DRI 1997 Desert Research Institute (DRI), Draft Analysis of Ambient Airborne Particulate Matter for Plutonium; Clean Slate 1 During Excavation and Truck Loading, Tonopah Test Range, May 1997 - June 1997, DRI Document Number 6357-683-7562.1D1. Prepared by DRI for the U.S. Department of Energy/Nevada Field Office, Las Vegas, NV (November 14, 1997).

DRI 1991 Desert Research Institute, Special Nevada Report, DOE/NV/10715-T1. Prepared by Science Applications International Corporation (SAIC) for the Department of the Air Force (September 23, 1991).

\section{Dunaway} and White, 1974

E\&E 1989

EG\&G 1995

EG\&G 1979

EPA 2005

EPA 1999

ERDA 1975

Essington and Fowler 1976

Funk 1985

Gilbert et al. 1975

U.S Department of Energy, Kauai Test Facility Environmental Assessment, DOE/EA-0492. U.S Department of Energy, Albuquerque Operations Office (DOE/AL), Albuquerque, NM (1992).

Dragun, J. and K. Chekiri, Elements in North American Soils. The Association for Environmental Health and Sciences, Amherst, MA (2005).

Dunaway, P.B. and M.G. White, The Dynamics of Plutonium in Desert Environments, Nevada Applied Ecology Group Progress Report, NVO-142. U.S. Atomic Energy Commission, Nevada Operations Office, Las Vegas, NV (1974).

Ecology and Environment, Inc., Federal Facility Preliminary Assessment Review, EPA Region IX, F9-8903-021, NV3570090016. Ecology and Environment, Inc., San Francisco, CA (1989).

Edgerton, Germeshausen \& Grier Corporation, Aerial Radiological Survey of the Tonopah Test Range Including Clean Slate 1, 2, 3, Roller Coaster, Decontamination Area, Cactus Springs Ranch Target Areas, Central Nevada, EGG-11265-1145. EG\&G Energy Measurements, Inc., Las Vegas, NV (1995).

Edgerton, Germeshausen \& Grier Corporation, Status of Endangered and Threatened Plant Species on Tonopah Test Range - A Survey, EGG-1183-2387. EG\&G, Las Vegas, NV (1979).

U.S. Environmental Protection Agency, "National Priorities List (NPL) Sites in the United States," available on the Web at http://www.epa.gov/superfund/sites/npl/npl.htm. U.S. Environmental Protection Agency, Washington, DC (2005).

U.S. Environmental Protection Agency, Off-site Environmental Monitoring Report: Radiation Monitoring Around United States Nuclear Test Areas, Calendar Year 1997, EPA/402-R-98-013, U.S. Environmental Protection Agency, Las Vegas, NV (1999).

U.S. Energy Research and Development Administration, Environmental Assessment, Tonopah Test Range, EIA/MA/76-2. U.S. Energy Research and Development Administration (ERDA), Washington, DC (1975).

Essington, E. H., and E. B. Fowler, "Distribution of Transuranic Nuclides in Soils," a review in Transuranics in Natural Environments, Report NVO-178. U.S. Energy Research and Development Administration, Las Vegas, NV (1976).

Funk, Evangeline J., Flora, Fauna, and Water Resources Report of the Pacific Missile Range Facility, Hawaiian Area, Kauai, HI. Prepared for the U.S. Navy by Botanical Consultants, Honolulu, HI (1985).

Gilbert, R. O., et al., "Statistical Analysis of ${ }^{239-240} \mathrm{Pu}$ and ${ }^{241} \mathrm{Am}$ Contamination of Soil and Vegetation on NAEG Study Sites," in The Radioecology of Plutonium and Other Transuranics in Desert Environments, Report NVO-153. U.S. Energy Research and Development Administration, Las Vegas, NV (1975). 
Gore 1993 Gore, Al., From Red Tape to Results: Creating a Government that Works Better and Costs Less (Report of the National Performance Review). U.S. Government Printing Office, Washington, DC (1993).

Hawaii Dept. “State of Hawaii Noncovered Source Permit No. 0429-01-N, ” Expiration Date 04/29/2009. State of Health, (DOH) 2004 of Hawaii DOH. Honolulu, HI (04/30/2004).

IT 1996 IT Corporation, Sampling and Analysis Plan for Clean Slate 1. IT Corporation (September 1996).

IT 1993 IT Corporation, Analytical Results for Tonopah Test Range, Transformer Oil Samples, Collected July 16-18, 1993. IT Corporation, Albuquerque, NM (September 1993).

KabataPendias and Pendias, 2000

Kabata-Pendias and Pendias, Trace Elements in Soils and Plants, 3rd. Ed. CRC Press, Inc., Boca Raton, FL (2000).

Leavitt 1980

Leavitt, V., Soil Profiles of Mounds on Plutonium-Contaminated Areas of the Nevada Test Range Complex. Environmental Monitoring Systems Laboratory, U.S. Environmental Protection Agency, Las Vegas, NV (1980).

Leavitt 1976 Leavitt, V., "Soil Surveys of Five Plutonium-Contaminated Areas on the Test Range Complex in Nevada," in Nevada Applied Ecology Group Procedures Handbook for Environmental Transuranics, Report NVO-166, Volume 1. National Environmental Research Center, Las Vegas, NV (1976).

McKague, McKague, H.L., P. Orkild, and S. Mattson, The Geology of the Nevada Test Site and Surrounding H.L., et al. $\quad$ Area, Field Trip Guidebook T186. American Geophysical Union, Washington D.C. (1989).

1989

NFEC 2003 Sandia National Laboratories, Spill Prevention Control and Countermeasures (SPCC) Plan, Pacific Missile Range Facility, Kauai, Hawaii. Prepared for Sandia National Laboratories by the Naval Facilities Engineer Command (NFEC), Environmental Division, Pearl Harbor, HI (2003).

Romney et al. Romney, E. M., et al., " ${ }^{\text {"239-240 }} \mathrm{Pu}$ and ${ }^{241}$ Am Contamination of Vegetation in Aged Plutonium 1975 Fallout Areas," in The Radioecology of Plutonium and Other Transuranics in Desert Environments, Report NVO-153. U.S. Energy Research and Development Administration, Las Vegas, NV (1975).

Schaeffer 1970 Schaeffer, J. R., Climatology of Tonopah Test Range, Nevada 1961-1969, SC-TM-70-0215. Sandia National Laboratories, Albuquerque, NM (1970).

Shyr, Herrera, Shyr, L, H. Herrera, R. Haaker, The Role of Data Analysis in Sampling Design of

Haaker 1998 Environmental Monitoring, SAND98-0612. Sandia National Laboratories, Albuquerque, NM (March 1998).

Sinnock 1982 Sinnock, S., Geology of the Nevada Test Site and Nearby Areas - Southern Nevada, SAND822207. Sandia National Laboratories, Albuquerque, NM (1982).

SNL 2005 Sandia National Laboratories, NESHAP Annual Report for CY 2004, Sandia National Laboratories, Nevada. Sandia National Laboratories, Albuquerque, NM (2005).

SNL 2005a Sandia National Laboratories, Tonopah Test Range Data Analysis in Support of the Annual Site Environmental Report, 2004. Sandia National Laboratories, Albuquerque, NM (July 2005).

SNL 2005b Sandia National Laboratories, "Noncovered Source Permit No. 0429-01-N: 2004 Annual Fee and Monitoring Report" (for Kauai Test Facility). Sandia National Laboratories, Albuquerque, NM. (February 23, 2005). 
SNL 2004 Sandia National Laboratories, Toxic Chemical Release Reporting Community Right-to-Know: Calendar Year 2003. Sandia National Laboratories, Albuquerque, NM (June 2004).

SNL 2004a

SNL 1999

SNL 1997

SNL 1996

SNL 1995

SNL 1993

SNL 1992

State of

Nevada 1997

Tamura 1977

Tamura 1976

Tamura 1975

USAF/DOE /NNSA 2002

USAF 1999
Sandia National Laboratories, 2003 Hazardous Waste Biennial Report for Sandia National Laboratories/New Mexico and Sandia National Laboratories/Tonopah Test Range, Sandia National Laboratories, Albuquerque, NM (March 2004).

Sandia National Laboratories, Spill Prevention Control and Countermeasures (SPCC) Plan for SNL Tonopah Test Range, Plan 90-12, Rev. 5. Sandia National Laboratories, Albuquerque, NM (August 2004).

Sandia National Laboratories, (1) NESHAP Annual Report for CY 1996 (EPA Summary) and (2) Radiological Dose Calculations and Supplemental Dose Assessment Data for NESHAP Compliance for Sandia National Laboratories, Nevada, CY 1996. Sandia National Laboratories, Albuquerque, NM (1997).

Sandia National Laboratories, (1) NESHAP Annual Report for CY 1995 (EPA Summary) and (2) Radiological Dose Calculations and Supplemental Dose Assessment Data for NESHAP Compliance for Sandia National Laboratories, Nevada, CY 1995. Sandia National Laboratories, Albuquerque, NM (1996).

Sandia National Laboratories, Site Inspection Report for the Kauai Test Facility. Sandia National Laboratories, Albuquerque, NM (April 1995).

"SNL Acoustic Monitoring Plan of the STARS Flight Test Unit 1." Memo to Linda Ninh from B.E. Swanson. Sandia National Laboratories, Albuquerque, NM (1993).

Sandia National Laboratories, "CDX Rocket Motor Effluent Monitoring," Memo from W.E. Stocum (7712) to R.G. Hay (2723). Sandia National Laboratories, Albuquerque, NM (1992).

State of Nevada, State of Nevada Bureau of Health Protection Services Vulnerability Assessment Contamination Monitoring Waiver. State of Nevada, (Sampling protocols for water quality, expiration date 2010) (October 21, 1997).

Tamura, T., "Plutonium Distribution in a Desert Pavement - Desert Mound Soil System in Area 11," in Environmental Plutonium on the Nevada Test Site and Environs, Report NVO-171. U.S. Energy Research and Development Administration, Las Vegas, NV (1977).

Tamura, T., "Plutonium Association in Soils," in Transuranics in Natural Environments, Report NVO-178. U.S. Energy Research and Development Administration, Las Vegas, NV (1976).

Tamura, T., "Characterization of Plutonium in Surface Soils from Area 13 of the Nevada Test Site," in The Radioecology of Plutonium and Other Transuranics in Desert Environments, Report NVO-153. U.S. Energy Research and Development Administration, Las Vegas, NV (1975).

U.S. Air Force/DOE/NNSA, Department of the Air Force Permit to the National Nuclear Security Administration to use Property Located on the Nevada Test and Training Range, Nevada. U.S. Air Force/DOE/NNSA, Tonopah, Nevada (2002).

U.S. Air Force, Renewal of the Nellis Air Force Range Land Withdrawal: Department of the Air Force Legislative Environmental Impact Statement. U.S. Air Force, Nellis Air Force Range, Nevada (March 1999). 
EO 11990 Protection of Wetlands, as amended (May 24, 1977).

EO 11988 Floodplain Management, as amended (May 24, 1977).

EO 12898 Federal Actions To Address Environmental Justice in Minority Populations and Low-Income Populations, as amended (February 11, 1994).

EO 13101 Greening the Government Through Waste Prevention, Recycling, and Federal Acquisition (September 14, 1998).

EO 13123 Greening the Government Through Efficiency Energy Management (June 3, 1999).

EO 13148 Greening the Government Through Leadership in Environmental Management (April 21, 2000).

EO 13149 Greening the Government Through Federal Fleet and Transportation Efficiency (April 21, 2000).

\section{$\underline{D O E}$ ORDERS}

DOE 2005 U.S. Department of Energy, Environmental Protection Program, DOE Order 450.1, Change 1. U.S. Department of Energy, Washington, DC (January 15, 2005).

DOE 2004a U.S. Department of Energy, Environment, Safety, and Health Reporting Manual, DOE Manual 231.11A, Change 1. U.S. Department of Energy, Washington, DC (September 9, 2004).

DOE 2004b U.S. Department of Energy, Environment, Safety, and Health Reporting, DOE Order 231.1-1A. U.S. Department of Energy, Washington, DC (June 3, 2004).

DOE 2003 U.S. Department of Energy, Occurrence Reporting and Processing of Operations Information, DOE Order 231.1-2. U.S. Department of Energy, Washington, DC (August 18, 2003).

DOE 2002 U.S. Department of Energy, Independent Oversight and Performance Assurance Program, DOE Order 470.2B. U.S. Department of Energy, Washington, DC (October 31, 2002).

DOE 2001 U.S. Department of Energy, National Environmental Policy Act Compliance Program, DOE Order 451.1B. U.S. Department of Energy, Washington, DC (September 28, 2001).

DOE 2001a U.S. Department of Energy, Radioactive Waste Management, DOE Order 435.1, Change 1. U.S. Department of Energy, Washington, DC (August 28, 2001).

DOE 1993 U.S. Department of Energy, Radiation Protection of the Public and the Environment, DOE Order 5400.5. U.S. Department of Energy, Washington, DC (January 7, 1993).

DOE 1993a U.S. Department of Energy, Environmental Compliance Issue Coordination, DOE/AL 5400.2A. U.S. Department of Energy, Albuquerque Field Office, Albuquerque, NM (July 13,1993).

\section{CODE OF FEDERAL REGULATIONS}

10 CFR 1021 "National Environmental Policy Act Implementing Procedures"

40 CFR 61 "National Emission Standards for Hazardous Air Pollutants (NESHAP)"

40 CFR 110 "Discharge of Oil"

40 CFR 112 “Oil Pollution Prevention”

40 CFR 141.26 "Monitoring Frequency and Compliance Requirements for Radionuclides in Community Water Systems" 
40 CFR 270 "EPA Administered Permit Programs: The Hazardous Waste Permit Program"

40 CFR 280 "Technical Standards and Corrective Action Requirements for Owners and Operators of Underground Storage Tanks"

40 CFR 355 "Emergency Planning and Notification"

40 CFR 370 "Hazardous Chemical Reporting: Community Right-to-Know"

40 CFR 122 "EPA Administered Permit Programs: The National Pollutant Discharge Elimination System"

\title{
ACTS \& STATUTES
}

- American Indian Religious Freedom Act (AIRFA) of 1978 (42 U.S.C. §1996).

- Archaeological Resources Protection Act (ARPA) of 1979 (16 U.S.C. § 470aa).

- $\quad$ Atomic Energy Act (AEA) of 1954 (42 U.S.C. \$2011 et seq.).

- Clean Air Act (CAA) and CAA Amendments (CAAA) of 1990 (42 U.S.C. §7401).

- Clean Water Act (CWA) of 1977 (The Federal Water Pollution Control Act) (33 U.S.C. §1251).

- Comprehensive Environmental Response, Compensation, and Liability Act (CERCLA) of 1980 (42 U.S.C. §9601) (Amended by SARA).

- Emergency Planning and Community Right-to-Know Act (EPCRA) of 1986 (42 U.S.C. § 11001 et seq.) (Also known as SARA Title III).

- $\quad$ Endangered Species Act (ESA) (16 U.S.C. $\$ 1531$ et seq.).

- Federal Facility Compliance Act (FFCA) of 1992 (42 U.S.C. § 6961).

- Federal Insecticide, Fungicide, and Rodenticide Act (FIFRA) (7 U.S.C. § 136).

- Migratory Bird Treaty Act (MBTA) of 1918, as amended (16 U.S.C. $§ 703$ et seq.).

- National Environmental Policy Act (NEPA) of 1969 (42 U.S.C.§4321).

- National Historic Preservation Act of 1966 (16 U.S.C.§470).

- Pollution Prevention Act of 1990 (42 U.S.C. $\$ 13101$ et seq.).

- Quiet Communities Act of 1978 (42 U.S.C. $\$ 4901$ et seq.).

- Resource Conservation and Recovery Act (RCRA) of 1976 (42 U.S.C. § 6901 et seq.).

- Safe Drinking Water Act (SDWA) (42 U.S.C. §300f).

- Superfund Amendments and Reauthorization Act (SARA) of 1986 (see CERCLA).

- Toxic Substances Control Act (TSCA) of 1976 (15 U.S.C. §2601 et seq).

\section{STATE OF HAWAII ENVIRONMENTAL REGULATIONS}

\author{
Hawaii Administrative Rules (HAR), Title 11, Chapter 23, "Underground Injection Control" \\ Hawaii Administrative Rules (HAR), Title 11, Chapter 59, “Ambient Air Quality Standards"
}




\section{STATE OF NEVADA \\ ENVIRONMENTAL REGULATIONS}

Nevada regulatory information can be found at the Nevada State Legistlature website: http://www.leg.state.nv.us/

A listing of the Nevada Administration Code (NAC) can be found at: http://www.leg.state.nv.us/NAC/CHAPTERS.html

TABLE 6-1. State of Nevada Administrative Code (NAC) Applicable to the TTR

\begin{tabular}{|c|c|}
\hline Chapter 444, Sanitation & Applicable Sources or Activities \\
\hline NAC 444.570 to 444.7499 , "Solid Waste Disposal" & $\begin{array}{l}\text { - Disposal of construction debris } \\
\text { - Disposal of routine non-hazardous solid } \\
\text { - Dispos } \\
\text { Dispal of septic sludge }\end{array}$ \\
\hline NAC 444A.005 to 444A.500, "Programs for Recycling" & - Recyclable materials including waste tires \\
\hline \multicolumn{2}{|l|}{ Chapter 445A, Water Controls } \\
\hline NAC 445A.070 to 445A.348, "Water Pollution Control" & $\begin{array}{ll}\text { - } & \text { Septic tanks } \\
\text { - } & \text { Surface water runoff } \\
\end{array}$ \\
\hline NAC 445A.450 to 445A. 6731, "Public Water Systems" & - $\quad$ Production well sampling \\
\hline \multicolumn{2}{|l|}{ Chapter 445B, Air Controls } \\
\hline NAC 445B.001 to 445B.3497, "Air Pollution" & $\begin{array}{l}\text { - } \\
\text { - Hazen burning } \\
\text { vents } \\
\text { - } \begin{array}{l}\text { Disturbance of soils during construction } \\
\text { (particulate matter) }\end{array}\end{array}$ \\
\hline NAC 445B.400 to 445B.774, "Emissions From Engines" & $\begin{array}{ll}\text { - } & \text { Generators } \\
\text { - } & \text { Mobile sources } \\
\end{array}$ \\
\hline \multicolumn{2}{|l|}{ Chapter 504, Wildlife Management and Propagation* } \\
\hline $\begin{array}{l}\text { NAC } 504.110 \text { to } 504.340 \text {, "Wildlife Management Areas" } \\
\text { NAC } 504.510 \text { to } 504.550 \text {, "Alteration of Stream System } \\
\text { or Watershed" }\end{array}$ & $\begin{array}{l}\text { - } \quad \text { Road construction } \\
\text { - } \quad \text { Construction activities }\end{array}$ \\
\hline $\begin{array}{l}\text { NAC } 504.800 \text { to } 504.865, \text { "Preservation of Wild } \\
\text { Horses"** }\end{array}$ & $\begin{array}{l}\text { - General activities on the range in wild horse } \\
\text { areas }\end{array}$ \\
\hline \multicolumn{2}{|l|}{ Chapter 534, Underground Water and Wells } \\
\hline $\begin{array}{l}\text { NAC 534.010 to 534.450, "Underground Water and } \\
\text { Wells" }\end{array}$ & $\begin{array}{l}\text { - Drilling, operation, and abandonment of } \\
\text { wells }\end{array}$ \\
\hline
\end{tabular}

NOTE: ${ }^{*}$ This regulation provides protection to endangered, threatened, and sensitive species.

${ }^{* *}$ Two wild horse units encompass areas within the Nellis Air Force Range:

"Unit 252: That portion of Nye County ..... and those portions of the Nellis Air Force Range as authorized by the United States Department of Defense."

"Unit 253: That portion of Nye County ... including those portions of the Nellis Air Force Range as authorized by the United States Department of Defense and the Nevada Test Site as authorized by the United States Department of Energy." (NAC 504.21, "General Designation of Management Areas and Units")

TTR $=$ Tonopah Test Range 


\section{APPENDIX A \\ TERRESTRIAL SURVEILLANCE RESULTS \\ AND SAMPLING LOCATION MAPS \\ FOR TTR}

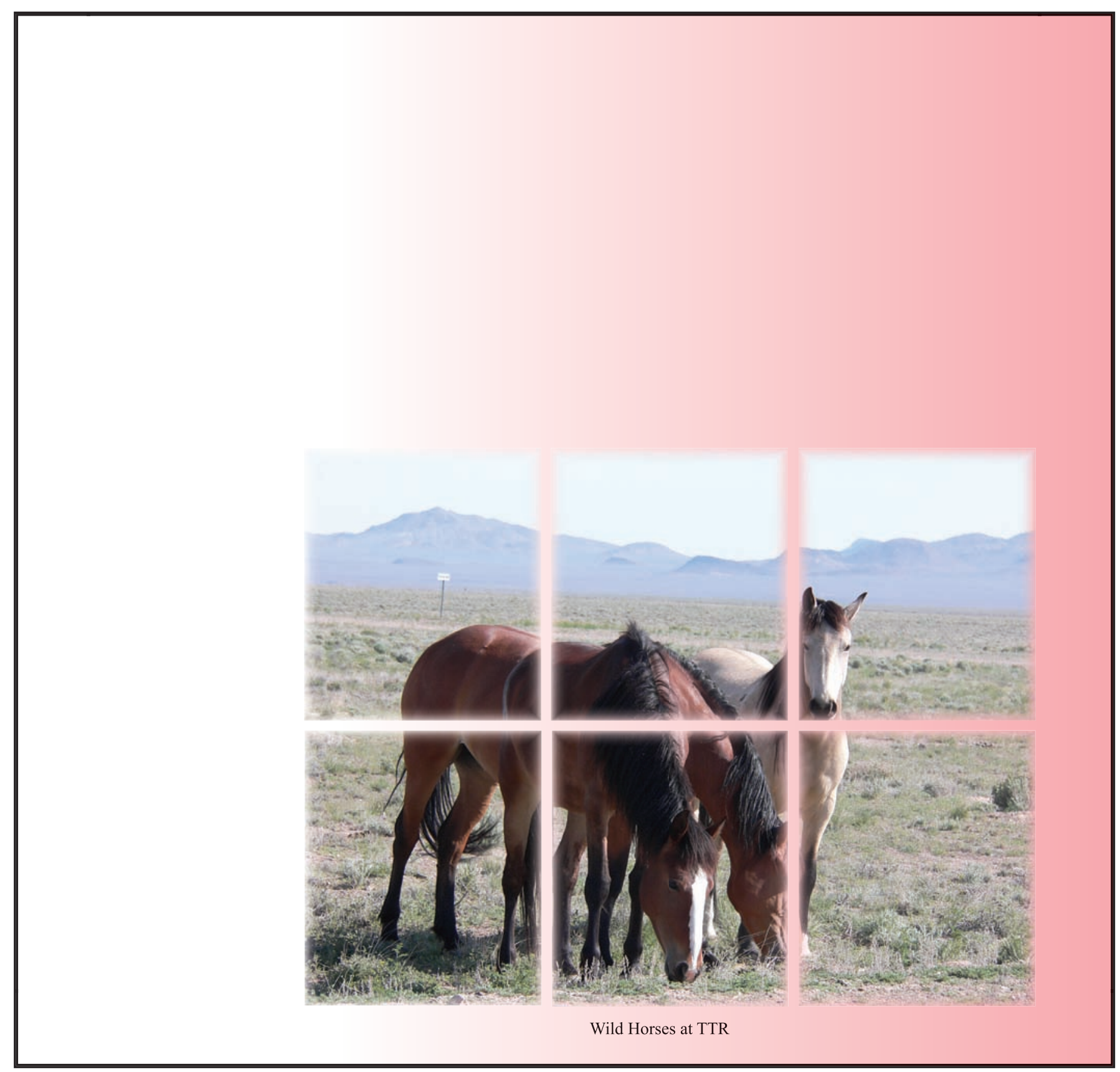


This page intentionally left blank. 


\section{CONTENTS}

\section{FIGURES}

A-1 Off-site Soil Sampling Locations (14 Locations) ............................................................................... A-3

A-2 Perimeter Soil Sampling Locations (Eight Locations) …………...................................................... A-7

A-3 Soil Sampling Locations in the South Plume Area (On-site) (Five locations) ......................................... A-10

A-4a Soil Sampling Locations in the Range Operations Center and Compound (On-site)

(Eight locations) ........ $\quad$ A-13

A-5a Various On-site Soil Sampling Locations (Five locations) ……............................................................. A-17

A-5b Various Soil Sampling Locations at Mellan Hill Area (Two locations) .................................................. A-18

$\begin{array}{ll}\text { A-5c } & \text { Soil Sampling Locations Near the Hard Target/Depleted Uranium } \\ & \text { Area (One location)... }\end{array}$

\section{TABLES}

A-1 Radiological Results for Off-site Soil Sampling Locations at TTR, 2004 ............................................ A-1

A-2 Radiological Results for Perimeter Soil Sampling Locations at TTR, 2004 .......................................... A-5

A-3 Radiological Results for South Plume Area On-site Soil Sampling

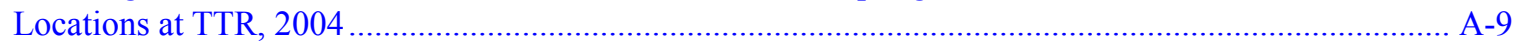

A-4 Radiological Results for Range Operations Center On-site

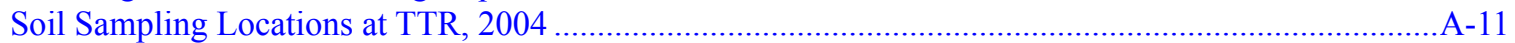

A-5 Radiological Results for Various On-site Soil Sampling Locations at TTR, 2004 ................................ A-15

A-6 Radiological Replicate Sampling for Soil Sampling Locations, 2004 ................................................. A-21

A-7 TLD Measurements by Quarter and Location Class for Calendar Year 2004 ........................................... A-23

A-8 Summary TLD Results for Calendar Year 2004, Tonopah Test Range ................................................... A-25 
This page intentionally left blank. 
TABLE A-1. Radiological Results for Off-site Soil Sampling Locations at TTR, 2004

\begin{tabular}{|c|c|c|c|c|c|c|}
\hline Location & Analyte & Units & Activity $( \pm 2 \sigma)$ & $\begin{array}{c}\text { Decision } \\
\text { Level }\end{array}$ & $\begin{array}{c}\text { Detection } \\
\text { Limit }\end{array}$ & $\begin{array}{c}\text { Lab } \\
\text { Qualifier }\end{array}$ \\
\hline \multirow{6}{*}{$\mathrm{C}-20$} & Americium-241 & $\mathrm{pCi} / \mathrm{g}$ & $0.0274 \pm 0.0313$ & 0.0305 & 0.0617 & $\mathrm{U}$ \\
\hline & Cesium-137 & $\mathrm{pCi} / \mathrm{g}$ & $0.194 \pm 0.0246$ & 0.00741 & 0.0151 & \\
\hline & Potassium-40 & $\mathrm{pCi} / \mathrm{g}$ & $27.8 \pm 1.9$ & 0.0647 & 0.134 & \\
\hline & Uranium-235 & $\mathrm{pCi} / \mathrm{g}$ & $0.0861 \pm 0.0829$ & 0.0529 & 0.107 & $\mathrm{U}$ \\
\hline & Uranium-238 & $\mathrm{pCi} / \mathrm{g}$ & $1.12 \pm 0.505$ & 0.253 & 0.511 & \\
\hline & Uranium & $\mathrm{mg} / \mathrm{kg}$ & 0.842 & 0.00592 & 0.0394 & \\
\hline \multirow{6}{*}{ C-21 } & Americium-241 & $\mathrm{pCi} / \mathrm{g}$ & $0.0478 \pm 0.036$ & 0.0301 & 0.0607 & UX \\
\hline & Cesium-137 & $\mathrm{pCi} / \mathrm{g}$ & $0.11 \pm 0.0374$ & 0.0137 & 0.028 & \\
\hline & Potassium-40 & $\mathrm{pCi} / \mathrm{g}$ & $27.7 \pm 1.87$ & 0.109 & 0.229 & \\
\hline & Uranium-235 & $\mathrm{pCi} / \mathrm{g}$ & $0.105 \pm 0.1$ & 0.0702 & 0.142 & $\mathrm{U}$ \\
\hline & Uranium-238 & $\mathrm{pCi} / \mathrm{g}$ & $1.18 \pm 0.553$ & 0.272 & 0.55 & \\
\hline & Uranium & $\mathrm{mg} / \mathrm{kg}$ & 0.92 & 0.00589 & 0.0393 & \\
\hline \multirow{6}{*}{$\mathrm{C}-22$} & Americium-241 & $\mathrm{pCi} / \mathrm{g}$ & $0.0363 \pm 0.0757$ & 0.0681 & 0.138 & $\mathrm{U}$ \\
\hline & Cesium-137 & $\mathrm{pCi} / \mathrm{g}$ & $0.0571 \pm 0.0361$ & 0.015 & 0.031 & \\
\hline & Potassium-40 & $\mathrm{pCi} / \mathrm{g}$ & $29.4 \pm 2.1$ & 0.122 & 0.262 & \\
\hline & Uranium-235 & $\mathrm{pCi} / \mathrm{g}$ & $0.00661 \pm 0.123$ & 0.0931 & 0.189 & $\mathrm{U}$ \\
\hline & Uranium-238 & $\mathrm{pCi} / \mathrm{g}$ & $1.14 \pm 0.874$ & 0.548 & 1.11 & \\
\hline & Uranium & $\mathrm{mg} / \mathrm{kg}$ & 0.582 & 0.00593 & 0.0395 & \\
\hline \multirow{6}{*}{$\mathrm{C}-23$} & Americium-241 & $\mathrm{pCi} / \mathrm{g}$ & $-0.147 \pm 0.104$ & 0.0815 & 0.166 & $\mathrm{U}$ \\
\hline & Cesium-137 & $\mathrm{pCi} / \mathrm{g}$ & $0.263 \pm 0.0421$ & 0.0127 & 0.0263 & \\
\hline & Potassium-40 & $\mathrm{pCi} / \mathrm{g}$ & $25.5 \pm 1.96$ & 0.101 & 0.216 & \\
\hline & Uranium-235 & $\mathrm{pCi} / \mathrm{g}$ & $0.0586 \pm 0.117$ & 0.0928 & 0.189 & $\mathrm{U}$ \\
\hline & Uranium-238 & $\mathrm{pCi} / \mathrm{g}$ & $0.471 \pm 0.981$ & 0.654 & 1.33 & $\mathrm{U}$ \\
\hline & Uranium & $\mathrm{mg} / \mathrm{kg}$ & 0.638 & 0.00587 & 0.0391 & \\
\hline \multirow{6}{*}{$\mathrm{C}-24$} & Americium-241 & $\mathrm{pCi} / \mathrm{g}$ & $-0.00523 \pm 0.0581$ & 0.0556 & 0.113 & $\mathrm{U}$ \\
\hline & Cesium-137 & $\mathrm{pCi} / \mathrm{g}$ & $0.192 \pm 0.0357$ & 0.0153 & 0.0317 & \\
\hline & Potassium-40 & $\mathrm{pCi} / \mathrm{g}$ & $30.4 \pm 2.2$ & 0.115 & 0.246 & \\
\hline & Uranium-235 & $\mathrm{pCi} / \mathrm{g}$ & $0.204 \pm 0.163$ & 0.0991 & 0.202 & \\
\hline & Uranium-238 & $\mathrm{pCi} / \mathrm{g}$ & $1.32 \pm 0.771$ & 0.487 & 0.991 & \\
\hline & Uranium & $\mathrm{mg} / \mathrm{kg}$ & 0.742 & 0.00592 & 0.0394 & \\
\hline \multirow{6}{*}{ C-25 } & Americium-241 & $\mathrm{pCi} / \mathrm{g}$ & $0.0377 \pm 0.0465$ & 0.0337 & 0.068 & UX \\
\hline & Cesium-137 & $\mathrm{pCi} / \mathrm{g}$ & $0.117 \pm 0.046$ & 0.015 & 0.0307 & \\
\hline & Potassium-40 & $\mathrm{pCi} / \mathrm{g}$ & $28.7 \pm 1.96$ & 0.12 & 0.252 & \\
\hline & Uranium-235 & $\mathrm{pCi} / \mathrm{g}$ & $0.0406 \pm 0.134$ & 0.0792 & 0.16 & $\mathrm{U}$ \\
\hline & Uranium-238 & $\mathrm{pCi} / \mathrm{g}$ & $1.19 \pm 0.619$ & 0.304 & 0.613 & \\
\hline & Uranium & $\mathrm{mg} / \mathrm{kg}$ & 1.07 & 0.00588 & 0.0392 & \\
\hline \multirow{6}{*}{$\mathrm{C}-26$} & Americium-241 & $\mathrm{pCi} / \mathrm{g}$ & $0.0354 \pm 0.0827$ & 0.0558 & 0.113 & $\mathrm{U}$ \\
\hline & Cesium-137 & $\mathrm{pCi} / \mathrm{g}$ & $0.583 \pm 0.0485$ & 0.00858 & 0.0175 & \\
\hline & Potassium-40 & $\mathrm{pCi} / \mathrm{g}$ & $30.5 \pm 2.2$ & 0.0721 & 0.15 & \\
\hline & Uranium-235 & $\mathrm{pCi} / \mathrm{g}$ & $0.0811 \pm 0.0852$ & 0.0569 & 0.115 & UX \\
\hline & Uranium-238 & $\mathrm{pCi} / \mathrm{g}$ & $0.987 \pm 0.817$ & 0.426 & 0.861 & \\
\hline & Uranium & $\mathrm{mg} / \mathrm{kg}$ & 0.832 & 0.006 & 0.04 & \\
\hline \multirow{6}{*}{$\mathrm{C}-27$} & Americium-241 & $\mathrm{pCi} / \mathrm{g}$ & $0.0414 \pm 0.0565$ & 0.0548 & 0.111 & $\mathrm{U}$ \\
\hline & Cesium-137 & $\mathrm{pCi} / \mathrm{g}$ & $0.164 \pm 0.0256$ & 0.011 & 0.0226 & \\
\hline & Potassium-40 & $\mathrm{pCi} / \mathrm{g}$ & $32.5 \pm 2.17$ & 0.0911 & 0.192 & \\
\hline & Uranium-235 & $\mathrm{pCi} / \mathrm{g}$ & $0.0509 \pm 0.095$ & 0.0664 & 0.134 & $\mathrm{U}$ \\
\hline & Uranium-238 & $\mathrm{pCi} / \mathrm{g}$ & $1.12 \pm 0.695$ & 0.434 & 0.879 & \\
\hline & Uranium & $\mathrm{mg} / \mathrm{kg}$ & 0.631 & 0.00592 & 0.0394 & \\
\hline
\end{tabular}


TABLE A-1. Radiological Results for Off-site Soil Sampling Locations at TTR, 2004 (concluded)

\begin{tabular}{|c|c|c|c|c|c|c|}
\hline Location & Analyte & Units & Activity $( \pm 2 \sigma)$ & $\begin{array}{c}\text { Decision } \\
\text { Level }\end{array}$ & $\begin{array}{c}\text { Detection } \\
\text { Limit }\end{array}$ & $\begin{array}{c}\text { Lab } \\
\text { Qualifier }\end{array}$ \\
\hline \multirow{6}{*}{ C-28 } & Americium-241 & $\mathrm{pCi} / \mathrm{g}$ & $0.00976 \pm 0.0433$ & 0.0431 & 0.0874 & $\mathrm{U}$ \\
\hline & Cesium-137 & $\mathrm{pCi} / \mathrm{g}$ & $0.103 \pm 0.0181$ & 0.00885 & 0.0182 & \\
\hline & Potassium-40 & $\mathrm{pCi} / \mathrm{g}$ & $30 \pm 1.98$ & 0.0748 & 0.158 & \\
\hline & Uranium-235 & $\mathrm{pCi} / \mathrm{g}$ & $0.0835 \pm 0.101$ & 0.0573 & 0.116 & UX \\
\hline & Uranium-238 & $\mathrm{pCi} / \mathrm{g}$ & $0.796 \pm 0.601$ & 0.34 & 0.688 & \\
\hline & Uranium & $\mathrm{mg} / \mathrm{kg}$ & 0.705 & 0.00592 & 0.0394 & \\
\hline \multirow{6}{*}{ C-29 } & Americium-241 & $\mathrm{pCi} / \mathrm{g}$ & $0.014 \pm 0.0676$ & 0.0619 & 0.125 & $\mathrm{U}$ \\
\hline & Cesium-137 & $\mathrm{pCi} / \mathrm{g}$ & $0.112 \pm 0.0187$ & 0.00853 & 0.0176 & \\
\hline & Potassium-40 & $\mathrm{pCi} / \mathrm{g}$ & $17.3 \pm 1.31$ & 0.0872 & 0.183 & \\
\hline & Uranium-235 & $\mathrm{pCi} / \mathrm{g}$ & $0.156 \pm 0.112$ & 0.0637 & 0.129 & \\
\hline & Uranium-238 & $\mathrm{pCi} / \mathrm{g}$ & $1.04 \pm 0.868$ & 0.475 & 0.962 & \\
\hline & Uranium & $\mathrm{mg} / \mathrm{kg}$ & 1.05 & 0.00594 & 0.0396 & \\
\hline \multirow{6}{*}{$\mathrm{C}-30$} & Americium-241 & $\mathrm{pCi} / \mathrm{g}$ & $0.0141 \pm 0.0165$ & 0.0148 & 0.0298 & $\mathrm{U}$ \\
\hline & Cesium-137 & $\mathrm{pCi} / \mathrm{g}$ & $0.284 \pm 0.0363$ & 0.0103 & 0.0209 & \\
\hline & Potassium-40 & $\mathrm{pCi} / \mathrm{g}$ & $29.4 \pm 1.88$ & 0.0841 & 0.174 & \\
\hline & Uranium-235 & $\mathrm{pCi} / \mathrm{g}$ & $0.101 \pm 0.0905$ & 0.0537 & 0.108 & $\mathrm{U}$ \\
\hline & Uranium-238 & $\mathrm{pCi} / \mathrm{g}$ & $0.545 \pm 0.341$ & 0.141 & 0.285 & \\
\hline & Uranium & $\mathrm{mg} / \mathrm{kg}$ & 0.601 & 0.00595 & 0.0397 & \\
\hline \multirow{6}{*}{$\mathrm{C}-31$} & Americium-241 & $\mathrm{pCi} / \mathrm{g}$ & $-0.0685 \pm 0.0911$ & 0.0843 & 0.171 & $\mathrm{U}$ \\
\hline & Cesium-137 & $\mathrm{pCi} / \mathrm{g}$ & $0.208 \pm 0.0314$ & 0.0113 & 0.0233 & \\
\hline & Potassium-40 & $\mathrm{pCi} / \mathrm{g}$ & $31.3 \pm 2.27$ & 0.0906 & 0.191 & \\
\hline & Uranium-235 & $\mathrm{pCi} / \mathrm{g}$ & $0.0645 \pm 0.0901$ & 0.0752 & 0.152 & $\mathrm{U}$ \\
\hline & Uranium-238 & $\mathrm{pCi} / \mathrm{g}$ & $0.898 \pm 1.02$ & 0.635 & 1.28 & UX \\
\hline & Uranium & $\mathrm{mg} / \mathrm{kg}$ & 0.877 & 0.00591 & 0.0394 & \\
\hline \multirow{6}{*}{$\mathrm{C}-32$} & Americium-241 & $\mathrm{pCi} / \mathrm{g}$ & $0.0248 \pm 0.0754$ & 0.0485 & 0.0981 & $\mathrm{U}$ \\
\hline & Cesium-137 & $\mathrm{pCi} / \mathrm{g}$ & $0.144 \pm 0.0212$ & 0.00773 & 0.0158 & \\
\hline & Potassium-40 & $\mathrm{pCi} / \mathrm{g}$ & $32.5 \pm 2.34$ & 0.0645 & 0.134 & \\
\hline & Uranium-235 & $\mathrm{pCi} / \mathrm{g}$ & $0.0587 \pm 0.0594$ & 0.0551 & 0.111 & UX \\
\hline & Uranium-238 & $\mathrm{pCi} / \mathrm{g}$ & $1.06 \pm 0.648$ & 0.401 & 0.81 & \\
\hline & Uranium & $\mathrm{mg} / \mathrm{kg}$ & 0.629 & 0.00596 & 0.0398 & \\
\hline \multirow{6}{*}{$\mathrm{C}-33$} & Americium-241 & $\mathrm{pCi} / \mathrm{g}$ & $-0.00359 \pm 0.0565$ & 0.0507 & 0.103 & $\mathrm{U}$ \\
\hline & Cesium-137 & $\mathrm{pCi} / \mathrm{g}$ & $0.0892 \pm 0.0202$ & 0.0107 & 0.022 & \\
\hline & Potassium-40 & $\mathrm{pCi} / \mathrm{g}$ & $29.4 \pm 2.11$ & 0.0909 & 0.192 & \\
\hline & Uranium-235 & $\mathrm{pCi} / \mathrm{g}$ & $0.0255 \pm 0.101$ & 0.0635 & 0.129 & $\mathrm{U}$ \\
\hline & Uranium-238 & $\mathrm{pCi} / \mathrm{g}$ & $0.56 \pm 0.602$ & 0.415 & 0.841 & UX \\
\hline & Uranium & $\mathrm{mg} / \mathrm{kg}$ & 0.676 & 0.00589 & 0.0393 & \\
\hline
\end{tabular}

Notes: $\quad \mathrm{pCi} / \mathrm{g}=$ picocurie per gram

$\mathrm{mg} / \mathrm{kg}=$ milligrams per kilogram

TTR $=$ Tonopah Test Range

$\mathrm{U}=$ The analyte was analyzed for, but not detected, below this concentration. For organic and inorganic analytes the result is less than the effective Decision Level. For radiochemical analytes

the result is less than the decision level.

$\mathrm{X}=$ Presumptive evidence that analyte is not present. 


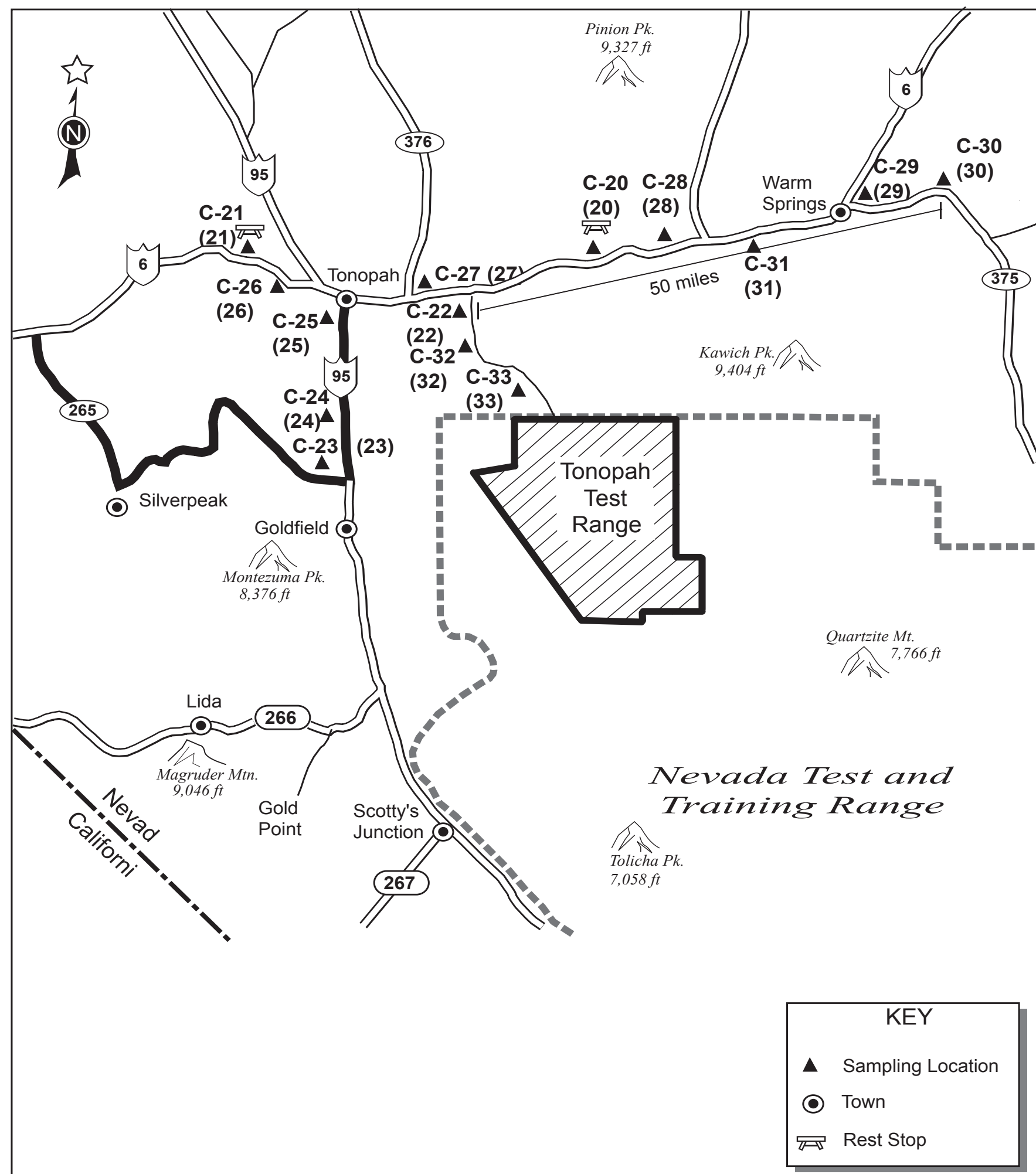

NOTE: The elevation of the town of Tonopah is $6,030 \mathrm{ft}$. 
This page intentionally left blank. 
TABLE A-2. Radiological Results for Perimeter Soil Sampling Locations at TTR, 2004

\begin{tabular}{|c|c|c|c|c|c|c|}
\hline Location & Analyte & Units & $\operatorname{Activity}( \pm 2 \sigma)$ & $\begin{array}{c}\text { Decision } \\
\text { Level }\end{array}$ & $\begin{array}{c}\text { Detection } \\
\text { Limit }\end{array}$ & $\begin{array}{c}\text { Lab } \\
\text { Qualifier }\end{array}$ \\
\hline \multirow{6}{*}{ P-06 } & Americium-241 & $\mathrm{pCi} / \mathrm{g}$ & $0.0279 \pm 0.0909$ & 0.0825 & 0.168 & $\mathrm{U}$ \\
\hline & Cesium-137 & $\mathrm{pCi} / \mathrm{g}$ & $0.221 \pm 0.031$ & 0.0131 & 0.027 & \\
\hline & Potassium-40 & $\mathrm{pCi} / \mathrm{g}$ & $30.3 \pm 2.26$ & 0.111 & 0.236 & \\
\hline & Uranium-235 & $\mathrm{pCi} / \mathrm{g}$ & $0.0688 \pm 0.12$ & 0.0788 & 0.16 & $\mathrm{U}$ \\
\hline & Uranium-238 & $\mathrm{pCi} / \mathrm{g}$ & $1.25 \pm 1.12$ & 0.611 & 1.24 & \\
\hline & Uranium & $\mathrm{mg} / \mathrm{kg}$ & 0.668 & 0.00595 & 0.0397 & \\
\hline \multirow{6}{*}{ P-08 } & Americium-241 & $\mathrm{pCi} / \mathrm{g}$ & $-0.00299 \pm 0.0808$ & 0.0692 & 0.141 & $\mathrm{U}$ \\
\hline & Cesium-137 & $\mathrm{pCi} / \mathrm{g}$ & $0.0903 \pm 0.028$ & 0.0147 & 0.0306 & \\
\hline & Potassium-40 & $\mathrm{pCi} / \mathrm{g}$ & $32 \pm 2.47$ & 0.118 & 0.255 & \\
\hline & Uranium-235 & $\mathrm{pCi} / \mathrm{g}$ & $0.135 \pm 0.148$ & 0.0943 & 0.192 & UX \\
\hline & Uranium-238 & $\mathrm{pCi} / \mathrm{g}$ & $0.965 \pm 0.96$ & 0.565 & 1.15 & UX \\
\hline & Uranium & $\mathrm{mg} / \mathrm{kg}$ & 0.635 & 0.00588 & 0.0392 & \\
\hline \multirow{6}{*}{$\mathrm{P}-11$} & Americium-241 & $\mathrm{pCi} / \mathrm{g}$ & $-0.0296 \pm 0.0655$ & 0.058 & 0.117 & $\mathrm{U}$ \\
\hline & Cesium-137 & $\mathrm{pCi} / \mathrm{g}$ & $0.143 \pm 0.0253$ & 0.012 & 0.0247 & \\
\hline & Potassium-40 & $\mathrm{pCi} / \mathrm{g}$ & $31 \pm 2.08$ & 0.0964 & 0.203 & \\
\hline & Uranium-235 & $\mathrm{pCi} / \mathrm{g}$ & $0.143 \pm 0.107$ & 0.0706 & 0.143 & \\
\hline & Uranium-238 & $\mathrm{pCi} / \mathrm{g}$ & $0.424 \pm 0.776$ & 0.481 & 0.973 & $\mathrm{U}$ \\
\hline & Uranium & $\mathrm{mg} / \mathrm{kg}$ & 0.582 & 0.00587 & 0.0391 & \\
\hline \multirow{6}{*}{$\mathrm{P}-12$} & Americium-241 & $\mathrm{pCi} / \mathrm{g}$ & $-0.016 \pm 0.0528$ & 0.0511 & 0.103 & $\mathrm{U}$ \\
\hline & Cesium-137 & $\mathrm{pCi} / \mathrm{g}$ & $0.275 \pm 0.0293$ & 0.0114 & 0.0234 & \\
\hline & Potassium-40 & $\mathrm{pCi} / \mathrm{g}$ & $33.4 \pm 2.28$ & 0.0952 & 0.2 & \\
\hline & Uranium-235 & $\mathrm{pCi} / \mathrm{g}$ & $0.0755 \pm 0.109$ & 0.0725 & 0.147 & $\mathrm{U}$ \\
\hline & \begin{tabular}{|l|} 
Uranium-238 \\
\end{tabular} & $\mathrm{pCi} / \mathrm{g}$ & $1.36 \pm 0.711$ & 0.404 & 0.817 & \\
\hline & Uranium & $\mathrm{mg} / \mathrm{kg}$ & 0.589 & 0.00599 & 0.0399 & \\
\hline \multirow{6}{*}{ P-34 } & Americium-241 & $\mathrm{pCi} / \mathrm{g}$ & $0.0304 \pm 0.0421$ & 0.0417 & 0.0843 & $\mathrm{U}$ \\
\hline & Cesium-137 & $\mathrm{pCi} / \mathrm{g}$ & $0.325 \pm 0.039$ & 0.0107 & 0.0218 & \\
\hline & \begin{tabular}{|l|} 
Potassium-40 \\
\end{tabular} & $\mathrm{pCi} / \mathrm{g}$ & $33.6 \pm 2.31$ & 0.0805 & 0.168 & \\
\hline & Uranium-235 & $\mathrm{pCi} / \mathrm{g}$ & $0.103 \pm 0.0963$ & 0.0695 & 0.141 & $\mathrm{U}$ \\
\hline & Uranium-238 & $\mathrm{pCi} / \mathrm{g}$ & $0.903 \pm 0.666$ & 0.356 & 0.719 & \\
\hline & Uranium & $\mathrm{mg} / \mathrm{kg}$ & 0.76 & 0.00587 & 0.0391 & \\
\hline \multirow{6}{*}{$\mathrm{P}-35$} & Americium-241 & $\mathrm{pCi} / \mathrm{g}$ & $-0.00554 \pm 0.0341$ & 0.0324 & 0.0653 & $\mathrm{U}$ \\
\hline & \begin{tabular}{|l|} 
Cesium-137 \\
\end{tabular} & $\mathrm{pCi} / \mathrm{g}$ & $0.321 \pm 0.0468$ & 0.0137 & 0.028 & \\
\hline & Potassium-40 & $\mathrm{pCi} / \mathrm{g}$ & $24.2 \pm 1.65$ & 0.104 & 0.218 & \\
\hline & Uranium-235 & $\mathrm{pCi} / \mathrm{g}$ & $0.0451 \pm 0.103$ & 0.0751 & 0.152 & $\mathrm{U}$ \\
\hline & Uranium-238 & $\mathrm{pCi} / \mathrm{g}$ & $0.747 \pm 0.489$ & 0.295 & 0.594 & \\
\hline & Uranium & $\mathrm{mg} / \mathrm{kg}$ & 1.49 & 0.00589 & 0.0393 & \\
\hline \multirow{6}{*}{ P-36 } & Americium-241 & $\mathrm{pCi} / \mathrm{g}$ & $-0.0182 \pm 0.0653$ & 0.057 & 0.115 & $\mathrm{U}$ \\
\hline & Cesium-137 & $\mathrm{pCi} / \mathrm{g}$ & $0.0922 \pm 0.019$ & 0.00956 & 0.0196 & \\
\hline & Potassium-40 & $\mathrm{pCi} / \mathrm{g}$ & $31.6 \pm 2.39$ & 0.0815 & 0.171 & \\
\hline & Uranium-235 & $\mathrm{pCi} / \mathrm{g}$ & $0.0342 \pm 0.0861$ & 0.0558 & 0.113 & $\mathrm{U}$ \\
\hline & Uranium-238 & $\mathrm{pCi} / \mathrm{g}$ & $0.827 \pm 0.724$ & 0.441 & 0.892 & $\mathrm{U}$ \\
\hline & Uranium & $\mathrm{mg} / \mathrm{kg}$ & 0.737 & 0.00588 & 0.0392 & \\
\hline
\end{tabular}


TABLE A-2. Radiological Results for Perimeter Soil Sampling Locations at TTR, 2004 (concluded)

\begin{tabular}{|c|l|l|c|c|c|c|}
\hline \multirow{2}{*}{ Location } & \multicolumn{1}{|c|}{ Analyte } & \multicolumn{1}{|c|}{ Units } & Activity $\mathbf{( \pm 2} \boldsymbol{\sigma})$ & $\begin{array}{c}\text { Decision } \\
\text { Level }\end{array}$ & $\begin{array}{c}\text { Detection } \\
\text { Limit }\end{array}$ & $\begin{array}{c}\text { Lab } \\
\text { Qualifier }\end{array}$ \\
\hline \multirow{5}{*}{ P-37 } & Americium-241 & $\mathrm{pCi} / \mathrm{g}$ & $-0.00851 \pm 0.0682$ & 0.062 & 0.126 & $\mathrm{U}$ \\
\cline { 2 - 7 } & Cesium-137 & $\mathrm{pCi} / \mathrm{g}$ & $0.0445 \pm 0.019$ & 0.0115 & 0.0242 & \\
\cline { 2 - 7 } & Potassium-40 & $\mathrm{pCi} / \mathrm{g}$ & $30 \pm 2.18$ & 0.135 & 0.288 & \\
\cline { 2 - 7 } & Uranium-235 & $\mathrm{pCi} / \mathrm{g}$ & $0.034 \pm 0.0845$ & 0.0804 & 0.164 & $\mathrm{U}$ \\
\cline { 2 - 7 } & Uranium-238 & $\mathrm{pCi} / \mathrm{g}$ & $0.623 \pm 0.772$ & 0.497 & 1.01 & $\mathrm{UX}$ \\
\cline { 2 - 7 } & Uranium & $\mathrm{mg} / \mathrm{kg}$ & 0.746 & 0.00584 & 0.0389 & \\
\hline
\end{tabular}

Notes: $\quad \mathrm{pCi} / \mathrm{g}=$ picocurie per gram

$\mathrm{mg} / \mathrm{kg}=$ milligrams per kilogram

TTR $=$ Tonopah Test Range

$\mathrm{U}=$ The analyte was analyzed for, but not detected, below this concentration. For organic and inorganic analytes the result is less than the effective Decision Level. For radiochemical analytes the result is less than the decision level.

$\mathrm{X}=$ Presumptive evidence that analyte is not present. 


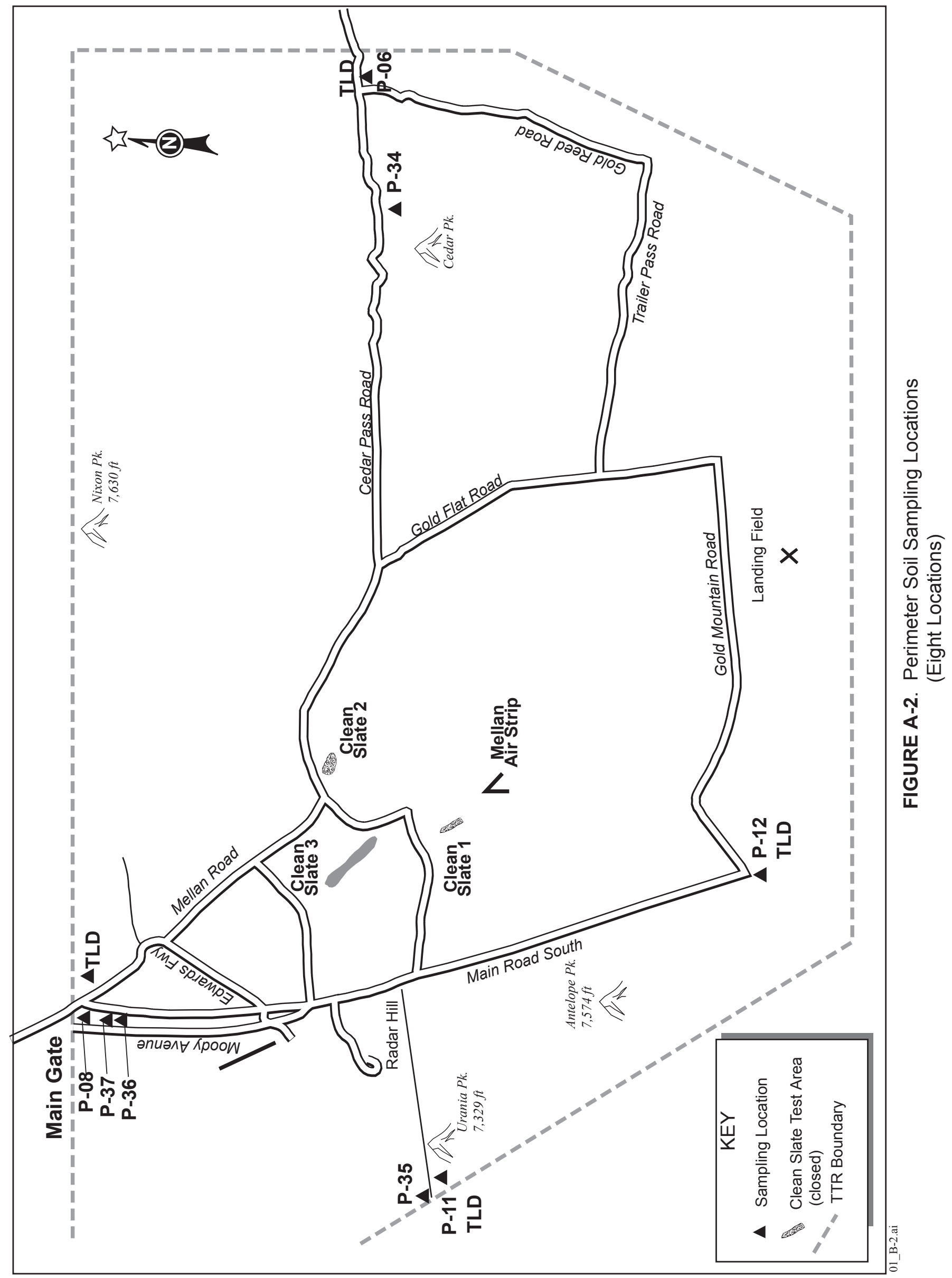

Appendix A 
This page intentionally left blank. 
TABLE A-3. Radiological Results for South Plume Area On-site Soil Sampling Locations at TTR, 2004

\begin{tabular}{|c|c|c|c|c|c|c|}
\hline Location & Analyte & Units & Activity $( \pm 2 \sigma)$ & $\begin{array}{c}\text { Decision } \\
\text { Level }\end{array}$ & $\begin{array}{c}\text { Detection } \\
\text { Limit }\end{array}$ & $\begin{array}{c}\text { Lab } \\
\text { Qualifier }\end{array}$ \\
\hline \multirow{6}{*}{ S-48 } & Americium-241 & $\mathrm{pCi} / \mathrm{g}$ & $0.00119 \pm 0.0394$ & 0.0374 & 0.0756 & $\mathrm{U}$ \\
\hline & Cesium-137 & $\mathrm{pCi} / \mathrm{g}$ & $0.428 \pm 0.0591$ & 0.0164 & 0.0336 & \\
\hline & Potassium-40 & $\mathrm{pCi} / \mathrm{g}$ & $28.8 \pm 1.98$ & 0.12 & 0.254 & \\
\hline & Uranium-235 & $\mathrm{pCi} / \mathrm{g}$ & $0.056 \pm 0.0953$ & 0.0861 & 0.174 & $\mathrm{U}$ \\
\hline & Uranium-238 & $\mathrm{pCi} / \mathrm{g}$ & $0.785 \pm 0.553$ & 0.339 & 0.684 & \\
\hline & Uranium & $\mathrm{mg} / \mathrm{kg}$ & 0.509 & 0.00596 & 0.0398 & \\
\hline \multirow{6}{*}{ S-49 } & Americium-241 & $\mathrm{pCi} / \mathrm{g}$ & $0.358 \pm 0.0377$ & 0.0188 & 0.038 & \\
\hline & Cesium-137 & $\mathrm{pCi} / \mathrm{g}$ & $0.417 \pm 0.0471$ & 0.0126 & 0.0256 & \\
\hline & Potassium-40 & $\mathrm{pCi} / \mathrm{g}$ & $32.1 \pm 2.07$ & 0.101 & 0.209 & \\
\hline & Uranium-235 & $\mathrm{pCi} / \mathrm{g}$ & $0.0992 \pm 0.07$ & 0.0646 & 0.131 & UX \\
\hline & Uranium-238 & $\mathrm{pCi} / \mathrm{g}$ & $1.35 \pm 0.383$ & 0.177 & 0.358 & \\
\hline & Uranium & $\mathrm{mg} / \mathrm{kg}$ & 0.743 & 0.006 & 0.04 & \\
\hline \multirow{6}{*}{ S-50 } & Americium-241 & $\mathrm{pCi} / \mathrm{g}$ & $-0.000176 \pm 0.0901$ & 0.0744 & 0.151 & $\mathrm{U}$ \\
\hline & Cesium-137 & $\mathrm{pCi} / \mathrm{g}$ & $0.398 \pm 0.034$ & 0.00946 & 0.0194 & \\
\hline & Potassium-40 & $\mathrm{pCi} / \mathrm{g}$ & $31.7 \pm 2.58$ & 0.08 & 0.168 & \\
\hline & Uranium-235 & $\mathrm{pCi} / \mathrm{g}$ & $0.00472 \pm 0.0846$ & 0.0639 & 0.129 & $\mathrm{U}$ \\
\hline & Uranium-238 & $\mathrm{pCi} / \mathrm{g}$ & $1.39 \pm 0.902$ & 0.515 & 1.05 & \\
\hline & Uranium & $\mathrm{mg} / \mathrm{kg}$ & 0.62 & 0.00593 & 0.0395 & \\
\hline \multirow{6}{*}{ S-51 } & Americium-241 & $\mathrm{pCi} / \mathrm{g}$ & $0.052 \pm 0.0539$ & 0.0468 & 0.0949 & $\mathrm{U}$ \\
\hline & Cesium-137 & $\mathrm{pCi} / \mathrm{g}$ & $0.391 \pm 0.0355$ & 0.0106 & 0.0218 & \\
\hline & Potassium-40 & $\mathrm{pCi} / \mathrm{g}$ & $29.9 \pm 2.06$ & 0.0958 & 0.201 & \\
\hline & Uranium-235 & $\mathrm{pCi} / \mathrm{g}$ & $0.0874 \pm 0.0964$ & 0.0632 & 0.128 & $\mathrm{U}$ \\
\hline & Uranium-238 & $\mathrm{pCi} / \mathrm{g}$ & $0.829 \pm 0.675$ & 0.387 & 0.783 & \\
\hline & Uranium & $\mathrm{mg} / \mathrm{kg}$ & 0.601 & 0.00594 & 0.0396 & \\
\hline \multirow{6}{*}{ S-52 } & Americium-241 & $\mathrm{pCi} / \mathrm{g}$ & $0.22 \pm 0.045$ & 0.0187 & 0.0378 & \\
\hline & Cesium-137 & $\mathrm{pCi} / \mathrm{g}$ & $0.335 \pm 0.0403$ & 0.0125 & 0.0257 & \\
\hline & Potassium-40 & $\mathrm{pCi} / \mathrm{g}$ & $30.3 \pm 1.94$ & 0.101 & 0.214 & \\
\hline & Uranium-235 & $\mathrm{pCi} / \mathrm{g}$ & $0.0361 \pm 0.0986$ & 0.064 & 0.13 & $\mathrm{U}$ \\
\hline & Uranium-238 & $\mathrm{pCi} / \mathrm{g}$ & $0.904 \pm 0.393$ & 0.184 & 0.373 & \\
\hline & Uranium & $\mathrm{mg} / \mathrm{kg}$ & 0.786 & 0.006 & 0.04 & \\
\hline
\end{tabular}

Notes: $\quad \mathrm{pCi} / \mathrm{g}=$ picocurie per gram

$\mathrm{mg} / \mathrm{kg}=$ milligrams per kilogram

TTR $=$ Tonopah Test Range

$\mathrm{U}=$ The analyte was analyzed for, but not detected, below this concentration. For organic and inorganic analytes the result is less than the effective Decision Level. For radiochemical analytes the result is less than the decision level.

$\mathrm{X}=$ Presumptive evidence that analyte is not present. 


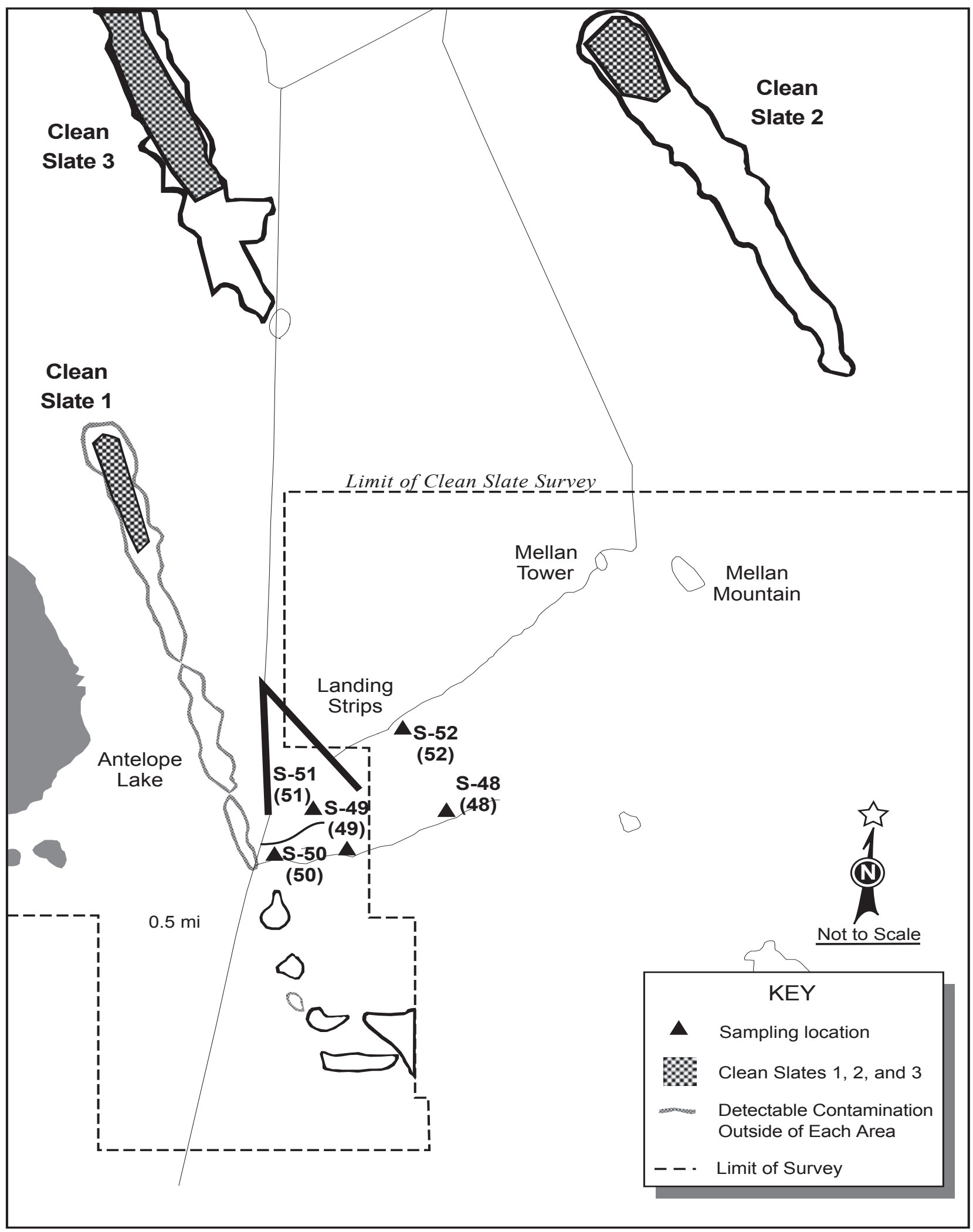

02_B-3.ai

FIGURE A-3. Soil Sampling Locations in the South Plume Area (on-site) (Five Locations) 
TABLE A-4. Radiological Results for Range Operations Center On-site Soil Sampling Locations at TTR, 2004

\begin{tabular}{|c|c|c|c|c|c|c|}
\hline Location & Analyte & Units & Activity $( \pm 2 \sigma)$ & $\begin{array}{c}\text { Decision } \\
\text { Level }\end{array}$ & $\begin{array}{c}\text { Detection } \\
\text { Limit }\end{array}$ & $\begin{array}{c}\text { Lab } \\
\text { Qualifier }\end{array}$ \\
\hline \multirow[t]{6}{*}{ S-40 } & Americium-241 & $\mathrm{pCi} / \mathrm{g}$ & $0.0339 \pm 0.0488$ & 0.0472 & 0.0958 & $\mathrm{U}$ \\
\hline & Cesium-137 & $\mathrm{pCi} / \mathrm{g}$ & $0.107 \pm 0.0246$ & 0.011 & 0.0227 & \\
\hline & Potassium-40 & $\mathrm{pCi} / \mathrm{g}$ & $33.6 \pm 2.34$ & 0.0987 & 0.207 & \\
\hline & Uranium-235 & $\mathrm{pCi} / \mathrm{g}$ & $0.118 \pm 0.122$ & 0.0804 & 0.163 & UX \\
\hline & Uranium-238 & $\mathrm{pCi} / \mathrm{g}$ & $1.33 \pm 0.783$ & 0.399 & 0.81 & \\
\hline & Uranium & $\mathrm{mg} / \mathrm{kg}$ & 0.802 & 0.00598 & 0.0398 & \\
\hline \multirow[t]{6}{*}{ S-41 } & Americium-241 & $\mathrm{pCi} / \mathrm{g}$ & $-0.000941 \pm 0.102$ & 0.0682 & 0.138 & $\mathrm{U}$ \\
\hline & Cesium-137 & $\mathrm{pCi} / \mathrm{g}$ & $0.301 \pm 0.0378$ & 0.0107 & 0.0219 & \\
\hline & Potassium-40 & $\mathrm{pCi} / \mathrm{g}$ & $28.9 \pm 2.14$ & 0.0819 & 0.173 & \\
\hline & Uranium-235 & $\mathrm{pCi} / \mathrm{g}$ & $0.0775 \pm 0.0788$ & 0.0784 & 0.159 & $\mathrm{U}$ \\
\hline & Uranium-238 & $\mathrm{pCi} / \mathrm{g}$ & $0.581 \pm 0.81$ & 0.558 & 1.13 & UX \\
\hline & Uranium & $\mathrm{mg} / \mathrm{kg}$ & 0.688 & 0.00583 & 0.0388 & \\
\hline \multirow[t]{6}{*}{ S-42 } & Americium-241 & $\mathrm{pCi} / \mathrm{g}$ & $0.0141 \pm 0.0582$ & 0.058 & 0.118 & $\mathrm{U}$ \\
\hline & Cesium-137 & $\mathrm{pCi} / \mathrm{g}$ & $0.358 \pm 0.05$ & 0.0144 & 0.0299 & \\
\hline & Potassium-40 & $\mathrm{pCi} / \mathrm{g}$ & $29.9 \pm 2.15$ & 0.0995 & 0.214 & \\
\hline & Uranium-235 & $\mathrm{pCi} / \mathrm{g}$ & $0.121 \pm 0.144$ & 0.099 & 0.202 & UX \\
\hline & Uranium-238 & $\mathrm{pCi} / \mathrm{g}$ & $0.706 \pm 0.784$ & 0.483 & 0.984 & UX \\
\hline & Uranium & $\mathrm{mg} / \mathrm{kg}$ & 0.713 & 0.00595 & 0.0397 & \\
\hline \multirow[t]{6}{*}{ S-43 } & Americium-241 & $\mathrm{pCi} / \mathrm{g}$ & $0.0121 \pm 0.0487$ & 0.0435 & 0.088 & $\mathrm{U}$ \\
\hline & Cesium-137 & $\mathrm{pCi} / \mathrm{g}$ & $0.0219 \pm 0.0177$ & 0.0101 & 0.0208 & \\
\hline & Potassium-40 & $\mathrm{pCi} / \mathrm{g}$ & $29 \pm 2$ & 0.0958 & 0.2 & \\
\hline & Uranium-235 & $\mathrm{pCi} / \mathrm{g}$ & $0.0713 \pm 0.0795$ & 0.0572 & 0.116 & UX \\
\hline & Uranium-238 & $\mathrm{pCi} / \mathrm{g}$ & $1.26 \pm 0.663$ & 0.345 & 0.698 & \\
\hline & Uranium & $\mathrm{mg} / \mathrm{kg}$ & 1.04 & 0.00588 & 0.0392 & \\
\hline \multirow[t]{6}{*}{ S-44 } & Americium-241 & $\mathrm{pCi} / \mathrm{g}$ & $-0.0248 \pm 0.0532$ & 0.0524 & 0.106 & $\mathrm{U}$ \\
\hline & Cesium-137 & $\mathrm{pCi} / \mathrm{g}$ & $0.0975 \pm 0.0216$ & 0.0109 & 0.0223 & \\
\hline & Potassium-40 & $\mathrm{pCi} / \mathrm{g}$ & $32.1 \pm 2.13$ & 0.0861 & 0.181 & \\
\hline & Uranium-235 & $\mathrm{pCi} / \mathrm{g}$ & $0.0625 \pm 0.0884$ & 0.0636 & 0.129 & $\mathrm{U}$ \\
\hline & Uranium-238 & $\mathrm{pCi} / \mathrm{g}$ & $0.466 \pm 0.704$ & 0.423 & 0.854 & UX \\
\hline & Uranium & $\mathrm{mg} / \mathrm{kg}$ & 0.757 & 0.00594 & 0.0396 & \\
\hline \multirow[t]{6}{*}{ S-45 } & Americium-241 & $\mathrm{pCi} / \mathrm{g}$ & $-0.00927 \pm 0.0478$ & 0.0467 & 0.0946 & $\mathrm{U}$ \\
\hline & Cesium-137 & $\mathrm{pCi} / \mathrm{g}$ & $0.0156 \pm 0.0114$ & 0.00971 & 0.02 & $\mathrm{U}$ \\
\hline & Potassium-40 & $\mathrm{pCi} / \mathrm{g}$ & $30.4 \pm 2.02$ & 0.0805 & 0.17 & \\
\hline & Uranium-235 & $\mathrm{pCi} / \mathrm{g}$ & $0.0813 \pm 0.0928$ & 0.0621 & 0.126 & UX \\
\hline & Uranium-238 & $\mathrm{pCi} / \mathrm{g}$ & $0.989 \pm 0.673$ & 0.376 & 0.762 & \\
\hline & Uranium & $\mathrm{mg} / \mathrm{kg}$ & 1.09 & 0.00586 & 0.0391 & \\
\hline \multirow[t]{6}{*}{ S-46 } & Americium-241 & $\mathrm{pCi} / \mathrm{g}$ & $-0.0234 \pm 0.0469$ & 0.0452 & 0.0914 & $\mathrm{U}$ \\
\hline & Cesium-137 & $\mathrm{pCi} / \mathrm{g}$ & $0.0235 \pm 0.0175$ & 0.0102 & 0.0208 & \\
\hline & Potassium-40 & $\mathrm{pCi} / \mathrm{g}$ & $31.3 \pm 2.12$ & 0.0808 & 0.169 & \\
\hline & Uranium-235 & $\mathrm{pCi} / \mathrm{g}$ & $0.0267 \pm 0.097$ & 0.0628 & 0.127 & $\mathrm{U}$ \\
\hline & Uranium-238 & $\mathrm{pCi} / \mathrm{g}$ & $1.12 \pm 0.677$ & 0.358 & 0.724 & \\
\hline & Uranium & $\mathrm{mg} / \mathrm{kg}$ & 0.728 & 0.00595 & 0.0397 & \\
\hline
\end{tabular}

See notes at end of table. 
TABLE A-4. Radiological Results for Range Operations Center On-Site Soil Sampling Locations at TTR, 2004 (concluded)

\begin{tabular}{|c|c|c|c|c|c|c|}
\hline Location & Analyte & Units & Activity $( \pm 2 \sigma)$ & $\begin{array}{c}\text { Decision } \\
\text { Level }\end{array}$ & $\begin{array}{c}\text { Detection } \\
\text { Limit }\end{array}$ & $\begin{array}{c}\text { Lab } \\
\text { Qualifier }\end{array}$ \\
\hline \multirow[t]{6}{*}{ S-47 } & Americium-241 & $\mathrm{pCi} / \mathrm{g}$ & $0.0428 \pm 0.0543$ & 0.0485 & 0.0983 & $\mathrm{U}$ \\
\hline & Cesium-137 & $\mathrm{pCi} / \mathrm{g}$ & $0.114 \pm 0.0201$ & 0.00992 & 0.0204 & \\
\hline & Potassium-40 & $\mathrm{pCi} / \mathrm{g}$ & $33.9 \pm 2.46$ & 0.0849 & 0.179 & \\
\hline & Uranium-235 & $\mathrm{pCi} / \mathrm{g}$ & $0.0791 \pm 0.085$ & 0.063 & 0.128 & UX \\
\hline & Uranium-238 & $\mathrm{pCi} / \mathrm{g}$ & $1.03 \pm 0.714$ & 0.382 & 0.773 & \\
\hline & Uranium & $\mathrm{mg} / \mathrm{kg}$ & 0.557 & 0.00592 & 0.0394 & \\
\hline
\end{tabular}

Notes: $\quad \mathrm{pCi} / \mathrm{g}=$ picocurie per gram $\mathrm{mg} / \mathrm{kg}=$ milligrams per kilogram

TTR $=$ Tonopah Test Range

$\mathrm{U}=$ The analyte was analyzed for, but not detected, below this concentration. For organic and inorganic analytes the result is less than the effective Decision Level. For radiochemical analytes the result is less than the decision level.

$\mathrm{X}=$ Presumptive evidence that analyte is not present. 


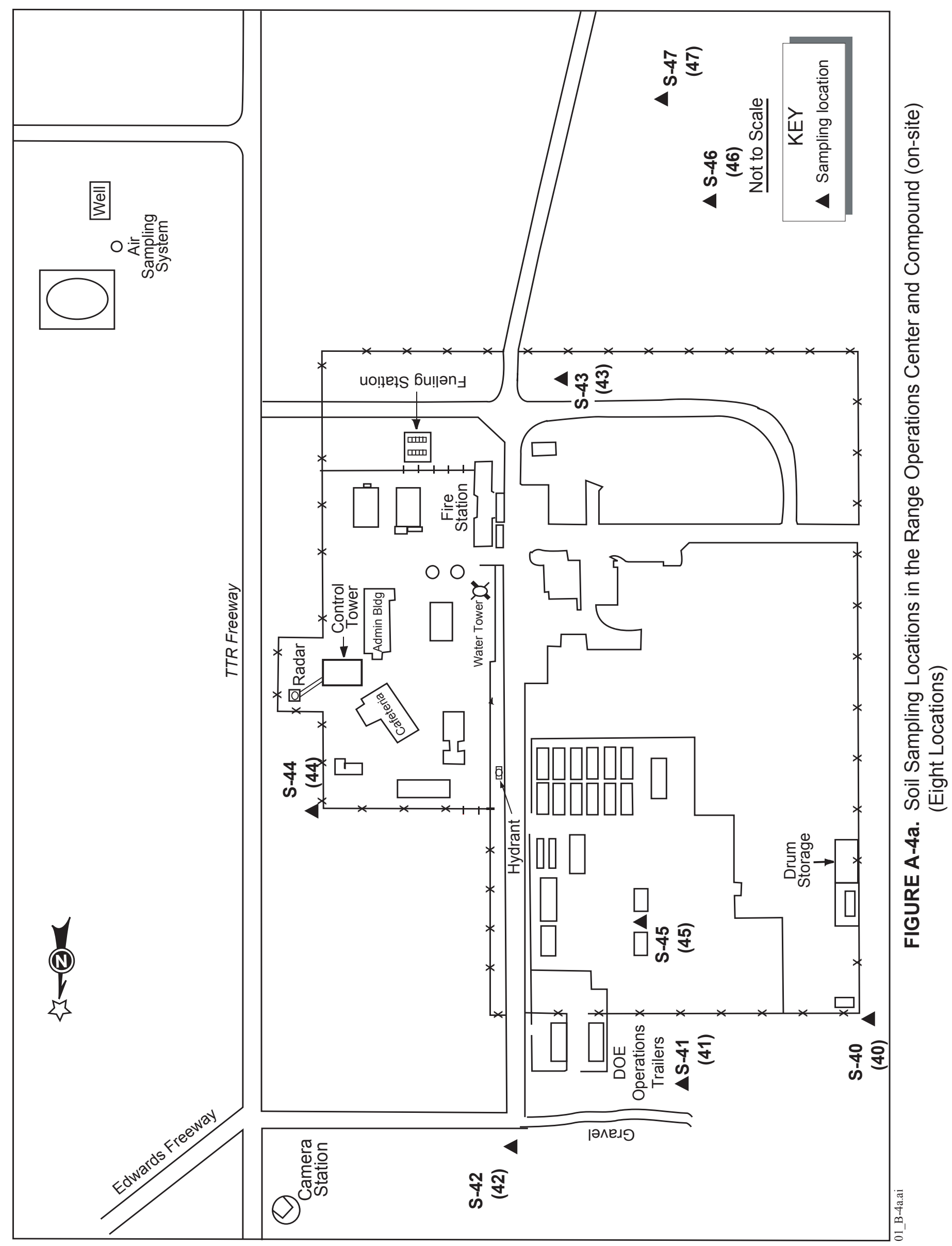

Appendix A

A-13 
This page intentionally left blank. 
TABLE A-5. Radiological Results for Various On-Site Soil Sampling Locations at TTR, 2004

\begin{tabular}{|c|c|c|c|c|c|c|}
\hline Location & Analyte & Units & Activity $( \pm 2 \sigma)$ & $\begin{array}{c}\text { Decision } \\
\text { Level }\end{array}$ & $\begin{array}{c}\text { Detection } \\
\text { Limit }\end{array}$ & $\begin{array}{c}\text { Lab } \\
\text { Qualifier }\end{array}$ \\
\hline \multirow{6}{*}{ S-02 } & Americium-241 & $\mathrm{pCi} / \mathrm{g}$ & $0.014 \pm 0.0351$ & 0.0339 & 0.0686 & $\mathrm{U}$ \\
\hline & Cesium-137 & $\mathrm{pCi} / \mathrm{g}$ & $0.342 \pm 0.0384$ & 0.00794 & 0.0162 & \\
\hline & Potassium-40 & $\mathrm{pCi} / \mathrm{g}$ & $35 \pm 2.38$ & 0.062 & 0.129 & \\
\hline & Uranium-235 & $\mathrm{pCi} / \mathrm{g}$ & $0.0839 \pm 0.0811$ & 0.0563 & 0.114 & $\mathrm{U}$ \\
\hline & Uranium-238 & $\mathrm{pCi} / \mathrm{g}$ & $0.928 \pm 0.544$ & 0.288 & 0.582 & \\
\hline & Uranium & $\mathrm{mg} / \mathrm{kg}$ & $1.01 \pm$ & 0.00596 & 0.0398 & \\
\hline \multirow{6}{*}{ S-03 } & Americium-241 & $\mathrm{pCi} / \mathrm{g}$ & $0.0506 \pm 0.0875$ & 0.0732 & 0.148 & $\mathrm{U}$ \\
\hline & Cesium-137 & $\mathrm{pCi} / \mathrm{g}$ & $0.333 \pm 0.0361$ & 0.0104 & 0.0212 & \\
\hline & Potassium-40 & $\mathrm{pCi} / \mathrm{g}$ & $31.9 \pm 2.28$ & 0.0686 & 0.144 & \\
\hline & Uranium-235 & $\mathrm{pCi} / \mathrm{g}$ & $0.119 \pm 0.0991$ & 0.0673 & 0.136 & $\mathrm{U}$ \\
\hline & Uranium-238 & $\mathrm{pCi} / \mathrm{g}$ & $0.809 \pm 0.886$ & 0.56 & 1.13 & UX \\
\hline & Uranium & $\mathrm{mg} / \mathrm{kg}$ & $0.823 \pm$ & 0.00598 & 0.0398 & \\
\hline \multirow{6}{*}{ S-04 } & Americium-241 & $\mathrm{pCi} / \mathrm{g}$ & $0.022 \pm 0.0575$ & 0.0562 & 0.114 & $\mathrm{U}$ \\
\hline & Cesium-137 & $\mathrm{pCi} / \mathrm{g}$ & $0.421 \pm 0.0607$ & 0.0138 & 0.0285 & \\
\hline & Potassium-40 & $\mathrm{pCi} / \mathrm{g}$ & $33.9 \pm 2.42$ & 0.115 & 0.244 & \\
\hline & Uranium-235 & $\mathrm{pCi} / \mathrm{g}$ & $0.231 \pm 0.162$ & 0.0997 & 0.203 & \\
\hline & Uranium-238 & $\mathrm{pCi} / \mathrm{g}$ & $1.58 \pm 0.981$ & 0.48 & 0.976 & \\
\hline & Uranium & $\mathrm{mg} / \mathrm{kg}$ & $0.729 \pm$ & 0.00589 & 0.0393 & \\
\hline \multirow{6}{*}{ S-09 } & Americium-241 & $\mathrm{pCi} / \mathrm{g}$ & $0.532 \pm 0.0891$ & 0.0413 & 0.0834 & \\
\hline & Cesium-137 & $\mathrm{pCi} / \mathrm{g}$ & $0.0911 \pm 0.0161$ & 0.0085 & 0.0174 & \\
\hline & Potassium-40 & $\mathrm{pCi} / \mathrm{g}$ & $28.1 \pm 2.03$ & 0.0715 & 0.149 & \\
\hline & Uranium-235 & $\mathrm{pCi} / \mathrm{g}$ & $0.0634 \pm 0.0641$ & 0.0519 & 0.105 & UX \\
\hline & Uranium-238 & $\mathrm{pCi} / \mathrm{g}$ & $1.04 \pm 0.553$ & 0.31 & 0.625 & \\
\hline & Uranium & $\mathrm{mg} / \mathrm{kg}$ & $0.612 \pm$ & 0.00598 & 0.0398 & \\
\hline \multirow{6}{*}{ S-10 } & Americium-241 & $\mathrm{pCi} / \mathrm{g}$ & $-0.101 \pm 0.0754$ & 0.058 & 0.117 & $\mathrm{U}$ \\
\hline & Cesium-137 & $\mathrm{pCi} / \mathrm{g}$ & $0.137 \pm 0.0203$ & 0.0087 & 0.0178 & \\
\hline & Potassium-40 & $\mathrm{pCi} / \mathrm{g}$ & $33.1 \pm 2.4$ & 0.0707 & 0.147 & \\
\hline & Uranium-235 & $\mathrm{pCi} / \mathrm{g}$ & $0.0564 \pm 0.0992$ & 0.0647 & 0.131 & $\mathrm{U}$ \\
\hline & Uranium-238 & $\mathrm{pCi} / \mathrm{g}$ & $1.03 \pm 0.755$ & 0.445 & 0.899 & \\
\hline & Uranium & $\mathrm{mg} / \mathrm{kg}$ & $0.831 \pm$ & 0.00596 & 0.0398 & \\
\hline \multirow{6}{*}{ S-38 } & Americium-241 & $\mathrm{pCi} / \mathrm{g}$ & $0.0295 \pm 0.0537$ & 0.0524 & 0.106 & $\mathrm{U}$ \\
\hline & Cesium-137 & $\mathrm{pCi} / \mathrm{g}$ & $0.311 \pm 0.0334$ & 0.00798 & 0.0163 & \\
\hline & Potassium-40 & $\mathrm{pCi} / \mathrm{g}$ & $35.4 \pm 2.65$ & 0.066 & 0.138 & \\
\hline & Uranium-235 & $\mathrm{pCi} / \mathrm{g}$ & $0.0831 \pm 0.0808$ & 0.0515 & 0.104 & UX \\
\hline & Uranium-238 & $\mathrm{pCi} / \mathrm{g}$ & $0.852 \pm 0.677$ & 0.397 & 0.801 & \\
\hline & Uranium & $\mathrm{mg} / \mathrm{kg}$ & $0.538 \pm$ & 0.00595 & 0.0397 & \\
\hline \multirow{6}{*}{ S-39 } & Americium-241 & $\mathrm{pCi} / \mathrm{g}$ & $0.0715 \pm 0.0663$ & 0.0608 & 0.123 & UX \\
\hline & Cesium-137 & $\mathrm{pCi} / \mathrm{g}$ & $0.336 \pm 0.0369$ & 0.0122 & 0.0252 & \\
\hline & Potassium-40 & $\mathrm{pCi} / \mathrm{g}$ & $31.3 \pm 2.1$ & 0.0867 & 0.186 & \\
\hline & Uranium-235 & $\mathrm{pCi} / \mathrm{g}$ & $0.0792 \pm 0.0972$ & 0.0769 & 0.156 & UX \\
\hline & Uranium-238 & $\mathrm{pCi} / \mathrm{g}$ & $0.967 \pm 0.653$ & 0.47 & 0.952 & \\
\hline & Uranium & $\mathrm{mg} / \mathrm{kg}$ & $0.735 \pm$ & 0.00596 & 0.0398 & \\
\hline
\end{tabular}


TABLE A-5. Radiological Results for Various On-Site Soil Sampling Locations at TTR, 2004 (concluded)

\begin{tabular}{|c|l|l|c|c|c|c|}
\hline \multirow{2}{*}{ Location } & \multicolumn{1}{|c|}{ Analyte } & \multicolumn{1}{|c|}{ Units } & Activity $\mathbf{( \pm 2} \boldsymbol{\sigma})$ & $\begin{array}{c}\text { Decision } \\
\text { Level }\end{array}$ & $\begin{array}{c}\text { Detection } \\
\text { Limit }\end{array}$ & $\begin{array}{c}\text { Lab } \\
\text { Qualifier }\end{array}$ \\
\hline \multirow{5}{*}{$\mathrm{S}-53$} & Americium-241 & $\mathrm{pCi} / \mathrm{g}$ & $-0.043 \pm 0.115$ & 0.0967 & 0.197 & $\mathrm{U}$ \\
\cline { 2 - 8 } & Cesium-137 & $\mathrm{pCi} / \mathrm{g}$ & $0.167 \pm 0.032$ & 0.0169 & 0.035 & \\
\cline { 2 - 8 } & Potassium-40 & $\mathrm{pCi} / \mathrm{g}$ & $31.4 \pm 2.4$ & 0.129 & 0.276 & \\
\cline { 2 - 8 } & Uranium-235 & $\mathrm{pCi} / \mathrm{g}$ & $0.116 \pm 0.154$ & 0.0999 & 0.203 & $\mathrm{UX}$ \\
\cline { 2 - 8 } & Uranium-238 & $\mathrm{pCi} / \mathrm{g}$ & $0.874 \pm 0.901$ & 0.734 & 1.5 & $\mathrm{UX}$ \\
\cline { 2 - 8 } & Uranium & $\mathrm{mg} / \mathrm{kg}$ & $0.598 \pm$ & 0.00587 & 0.0391 & \\
\hline
\end{tabular}

Notes: $\quad \mathrm{pCi} / \mathrm{g}=$ picocurie per gram

$\mathrm{mg} / \mathrm{kg}=$ milligrams per kilogram

TTR $=$ Tonopah Test Range

$\mathrm{U}=$ The analyte was analyzed for, but not detected, below this concentration. For organic and

inorganic analytes the result is less than the effective Decision Level. For radiochemical analytes

the result is less than the decision level.

$\mathrm{X}=$ Presumptive evidence that analyte is not present. 


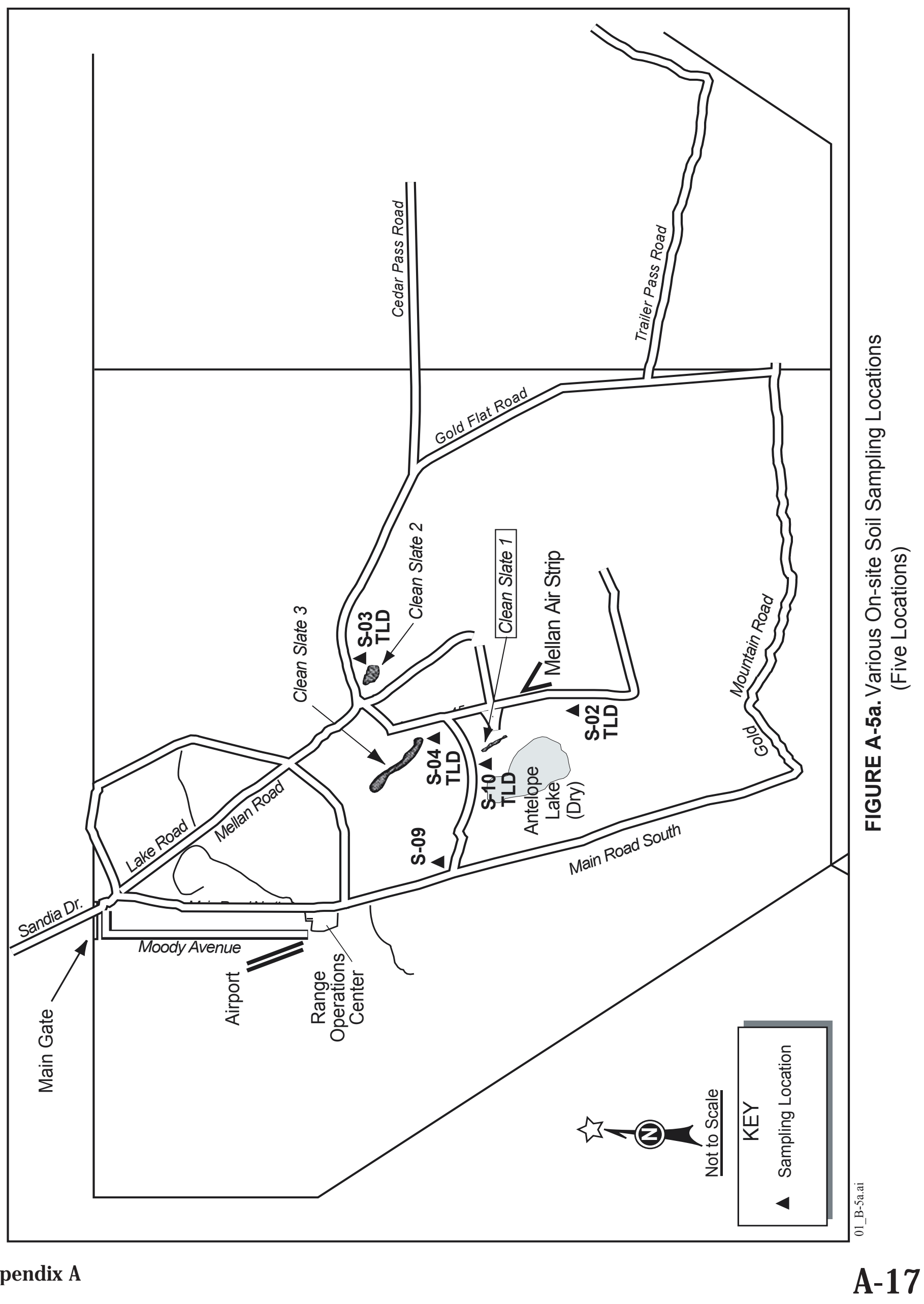




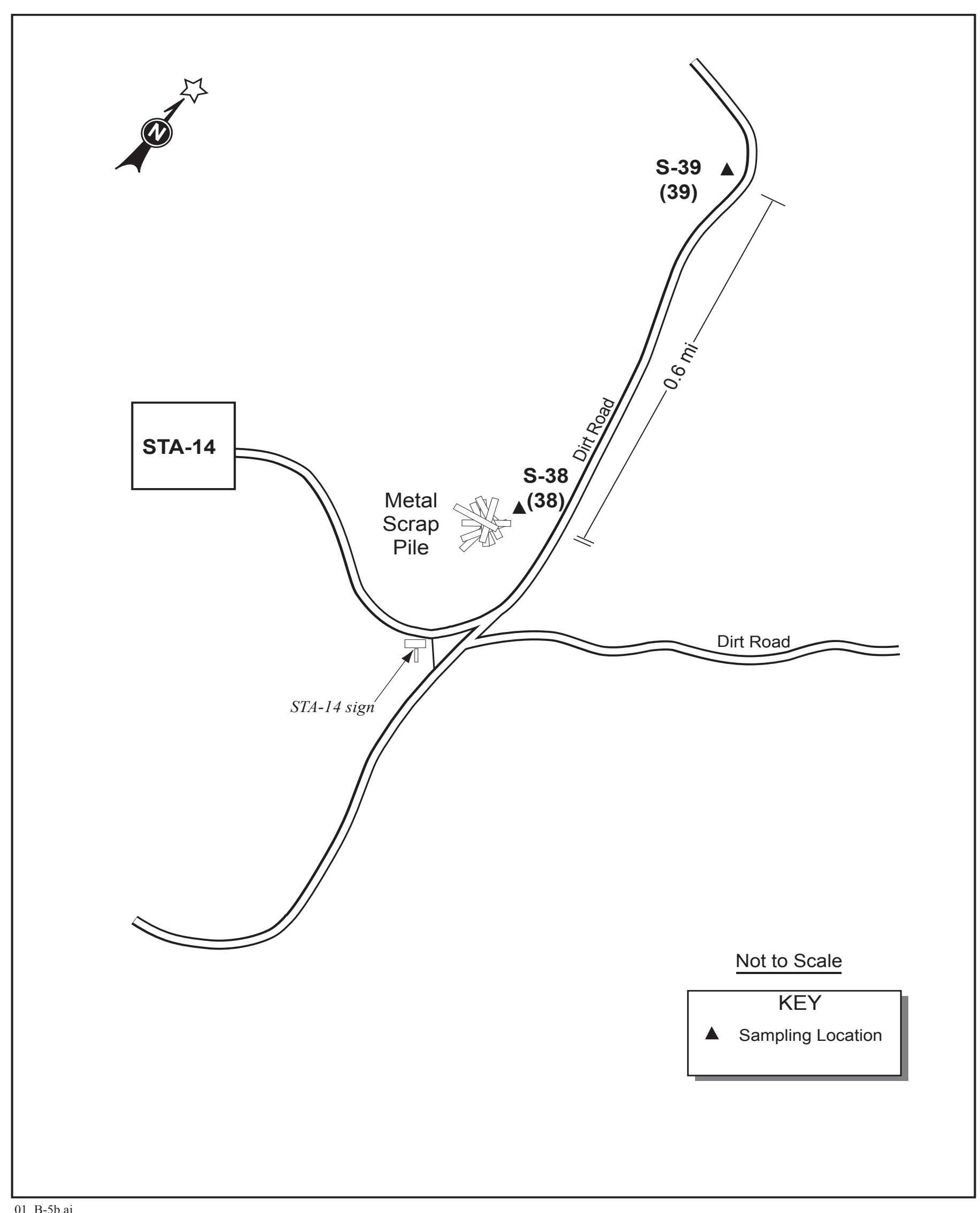

01_B-5b.ai

FIGURE A-5b Various Soil Sampling Locations at Mellan Hill Area (Two Locations) 


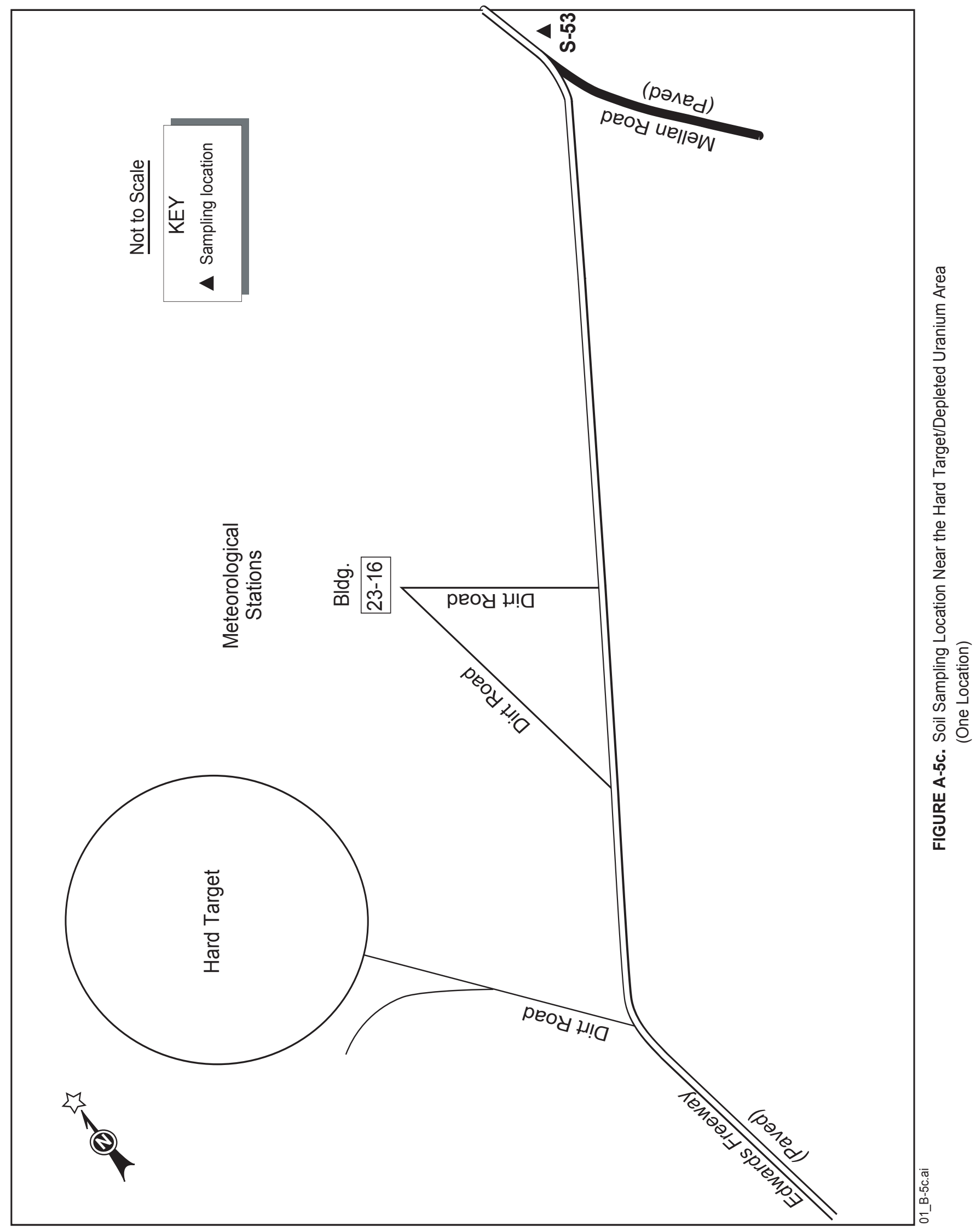

Appendix A 
This page intentionally left blank. 
TABLE A-6. Radiological Replicate Sampling for Soil Sampling Locations, 2004

\begin{tabular}{|c|c|c|c|c|c|c|c|c|c|c|c|c|}
\hline Location & Analyte & Units & $\begin{array}{c}\text { Sample } \\
\text { ID }\end{array}$ & Activity $( \pm 2 \sigma)$ & $\begin{array}{c}\text { Decision } \\
\text { Level }\end{array}$ & $\begin{array}{c}\text { Detection } \\
\text { Limit }\end{array}$ & $\begin{array}{c}\text { Lab } \\
\text { Qualifier }\end{array}$ & Avg & $\begin{array}{l}\text { Std } \\
\text { Dev }\end{array}$ & Min & $\operatorname{Max}$ & $\mathrm{CV} \%$ \\
\hline \multicolumn{13}{|c|}{ Off-Site } \\
\hline \multirow{12}{*}{$\mathrm{C}-29$} & \multirow{3}{*}{ Americium-241 } & \multirow{3}{*}{$\mathrm{pCi} / \mathrm{g}$} & 064741-01 & $0.014 \pm 0.0676$ & 0.0619 & 0.125 & U & -0.01 & 0.03 & -0.04 & 0.01 & $-3.06 \%$ \\
\hline & & & 064741-02 & $-0.0372 \pm 0.0619$ & 0.0513 & 0.104 & $\mathrm{U}$ & & & & & \\
\hline & & & 064741-03 & $-0.00241 \pm 0.0185$ & 0.0167 & 0.0338 & $\mathrm{U}$ & & & & & \\
\hline & \multirow{3}{*}{ Cesium-137 } & \multirow{3}{*}{$\mathrm{pCi} / \mathrm{g}$} & 064741-01 & $0.112 \pm 0.0187$ & 0.00853 & 0.0176 & & 0.14 & 0.05 & 0.11 & 0.19 & $0.34 \%$ \\
\hline & & & 064741-02 & $0.19 \pm 0.0237$ & 0.0101 & 0.0209 & & & & & & \\
\hline & & & 064741-03 & $0.108 \pm 0.0242$ & 0.0106 & 0.0218 & & & & & & \\
\hline & \multirow{3}{*}{ Potassium-40 } & \multirow{3}{*}{$\mathrm{pCi} / \mathrm{g}$} & 064741-01 & $17.3 \pm 1.31$ & 0.0872 & 0.183 & & 16.67 & 1.01 & 15.50 & 17.30 & $0.06 \%$ \\
\hline & & & 064741-02 & $17.2 \pm 1.3$ & 0.0855 & 0.181 & & & & & & \\
\hline & & & 064741-03 & $15.5 \pm 1.07$ & 0.0948 & 0.197 & & & & & & \\
\hline & \multirow{3}{*}{ Uranium } & \multirow{3}{*}{$\mu \mathrm{g} / \mathrm{g}$} & 064741-01 & 1.05 & 0.00594 & 0.0396 & & 0.99 & 0.09 & 0.89 & 1.05 & $0.09 \%$ \\
\hline & & & 064741-02 & 1.04 & 0.00587 & 0.0391 & & & & & & \\
\hline & & & 064741-03 & 0.891 & 0.00592 & 0.0394 & & & & & & \\
\hline \multicolumn{13}{|c|}{ Perimeter } \\
\hline \multirow{12}{*}{$\mathrm{P}-11$} & \multirow{3}{*}{ Americium-241 } & \multirow{3}{*}{$\mathrm{pCi} / \mathrm{g}$} & 064765-01 & $-0.0296 \pm 0.0655$ & 0.058 & 0.117 & $\mathrm{U}$ & -0.02 & 0.02 & -0.04 & 0.00 & $-0.96 \%$ \\
\hline & & & 064765-02 & $0.00145 \pm 0.0573$ & 0.052 & 0.105 & $\mathrm{U}$ & & & & & \\
\hline & & & $064765-03$ & $-0.0421 \pm 0.0617$ & 0.0572 & 0.116 & $\mathrm{U}$ & & & & & \\
\hline & \multirow{3}{*}{ Cesium-137 } & \multirow{3}{*}{$\mathrm{pCi} / \mathrm{g}$} & $064765-01$ & $0.143 \pm 0.0253$ & 0.012 & 0.0247 & & 0.10 & 0.04 & 0.07 & 0.14 & $0.38 \%$ \\
\hline & & & 064765-02 & $0.0677 \pm 0.0197$ & 0.0114 & 0.0235 & & & & & & \\
\hline & & & $064765-03$ & $0.0916 \pm 0.0182$ & 0.00916 & 0.0187 & & & & & & \\
\hline & \multirow{3}{*}{ Potassium-40 } & \multirow{3}{*}{$\mathrm{pCi} / \mathrm{g}$} & 064765-01 & $31 \pm 2.08$ & 0.0964 & 0.203 & & 31.90 & 0.79 & 31.00 & 32.50 & $0.02 \%$ \\
\hline & & & 064765-02 & $32.2 \pm 2.35$ & 0.0875 & 0.185 & & & & & & \\
\hline & & & 064765-03 & $32.5 \pm 2.35$ & 0.0684 & 0.142 & & & & & & \\
\hline & \multirow{3}{*}{ Uranium } & \multirow{3}{*}{$\mu \mathrm{g} / \mathrm{g}$} & 064765-01 & 0.582 & 0.00587 & 0.0391 & & 0.58 & 0.02 & 0.56 & 0.60 & $0.04 \%$ \\
\hline & & & 064765-02 & 0.555 & 0.00595 & 0.0397 & & & & & & \\
\hline & & & 064765-03 & 0.602 & 0.00598 & 0.0398 & & & & & & \\
\hline \multicolumn{13}{|c|}{ South Plume Area } \\
\hline \multirow{12}{*}{ S-03 } & \multirow{3}{*}{ Americium-241 } & & $064752-01$ & $0.0506 \pm 0.0875$ & 0.0732 & 0.148 & $\mathrm{U}$ & 0.06 & 0.03 & 0.04 & 0.10 & $0.47 \%$ \\
\hline & & $\mathrm{pCi} / \mathrm{g}$ & 064752-02 & $0.0419 \pm 0.026$ & 0.0187 & 0.0377 & & & & & & \\
\hline & & & $064752-03$ & $0.0977 \pm 0.0857$ & 0.0638 & 0.129 & UX & & & & & \\
\hline & & & 064752-01 & $0.333 \pm 0.0361$ & 0.0104 & 0.0212 & & 0.34 & 0.01 & 0.33 & 0.35 & $0.03 \%$ \\
\hline & Cesium-137 & $\mathrm{pCi} / \mathrm{g}$ & 064752-02 & $0.351 \pm 0.0397$ & 0.012 & 0.0245 & & & & & & \\
\hline & & & $064752-03$ & $0.348 \pm 0.04$ & 0.0106 & 0.0217 & & & & & & \\
\hline & & & 064752-01 & $31.9 \pm 2.28$ & 0.0686 & 0.144 & & 31.77 & 0.61 & 31.10 & 32.30 & $0.02 \%$ \\
\hline & Potassium-40 & $\mathrm{pCi} / \mathrm{g}$ & 064752-02 & $31.1 \pm 2.01$ & 0.104 & 0.217 & & & & & & \\
\hline & & & $064752-03$ & $32.3 \pm 2.36$ & 0.0744 & 0.156 & & & & & & \\
\hline & & & 064752-01 & 0.823 & 0.00598 & 0.0398 & & 0.84 & 0.03 & 0.82 & 0.88 & $0.04 \%$ \\
\hline & Uranium & $\mu \mathrm{g} / \mathrm{g}$ & 064752-02 & 0.878 & 0.00588 & 0.0392 & & & & & & \\
\hline & & & 064752-03 & 0.826 & 0.00583 & 0.0388 & & & & & & \\
\hline
\end{tabular}

See notes at end of table. 
TABLE A-6. Radiological Replicate Sampling for Soil Sampling Locations, 2004 (concluded)

\begin{tabular}{|c|c|c|c|c|c|c|c|c|c|c|c|c|}
\hline Location & Analyte & Units & $\begin{array}{c}\text { Sample } \\
\text { ID }\end{array}$ & $\operatorname{Activity}( \pm 2 \sigma)$ & $\begin{array}{c}\text { Decision } \\
\text { Level }\end{array}$ & $\begin{array}{c}\text { Detection } \\
\text { Limit }\end{array}$ & $\begin{array}{c}\text { Lab } \\
\text { Qualifier }\end{array}$ & Avg & $\begin{array}{l}\text { Std } \\
\text { Dev }\end{array}$ & Min & Max & CV\% \\
\hline \multicolumn{13}{|c|}{ Various On-Site } \\
\hline \multirow{12}{*}{ S-09 } & \multirow{3}{*}{ Americium-241 } & \multirow{3}{*}{$\mathrm{pCi} / \mathrm{g}$} & 064749-01 & $0.532 \pm 0.0891$ & 0.0413 & 0.0834 & & 0.69 & 0.27 & 0.53 & 1.00 & $0.39 \%$ \\
\hline & & & 064749-02 & $0.997 \pm 0.173$ & 0.057 & 0.115 & & & & & & \\
\hline & & & 064749-03 & $0.534 \pm 0.0451$ & 0.0163 & 0.0329 & & & & & & \\
\hline & \multirow{3}{*}{ Cesium-137 } & \multirow{3}{*}{$\mathrm{pCi} / \mathrm{g}$} & 064749-01 & $0.0911 \pm 0.0161$ & 0.0085 & 0.0174 & & 0.10 & 0.02 & 0.09 & 0.12 & $0.18 \%$ \\
\hline & & & 064749-02 & $0.121 \pm 0.0179$ & 0.00848 & 0.0173 & & & & & & \\
\hline & & & 064749-03 & $0.0891 \pm 0.022$ & 0.0107 & 0.0217 & & & & & & \\
\hline & \multirow{3}{*}{ Potassium-40 } & \multirow{3}{*}{$\mathrm{pCi} / \mathrm{g}$} & 064749-01 & $28.1 \pm 2.03$ & 0.0715 & 0.149 & & 28.67 & 0.81 & 28.10 & 29.60 & $0.03 \%$ \\
\hline & & & 064749-02 & $29.6 \pm 2.24$ & 0.0717 & 0.15 & & & & & & \\
\hline & & & 064749-03 & $28.3 \pm 1.81$ & 0.0878 & 0.182 & & & & & & \\
\hline & \multirow{3}{*}{ Uranium } & \multirow{3}{*}{$\mu \mathrm{g} / \mathrm{g}$} & 064749-01 & 0.612 & 0.00598 & 0.0398 & & 0.61 & 0.03 & 0.59 & 0.65 & $0.05 \%$ \\
\hline & & & 064749-02 & 0.645 & 0.006 & 0.04 & & & & & & \\
\hline & & & 064749-03 & 0.586 & 0.00593 & 0.0395 & & & & & & \\
\hline \multirow{12}{*}{ S-48 } & \multirow{3}{*}{ Americium-241 } & \multirow{3}{*}{$\mathrm{pCi} / \mathrm{g}$} & 064758-01 & $0.00119 \pm 0.0394$ & 0.0374 & 0.0756 & $\mathrm{U}$ & 0.00 & 0.01 & -0.02 & 0.01 & $-7.17 \%$ \\
\hline & & & 064758-02 & $-0.0174 \pm 0.0753$ & 0.0629 & 0.128 & $\mathrm{U}$ & & & & & \\
\hline & & & 064758-03 & $0.0103 \pm 0.0135$ & 0.0161 & 0.0324 & $\mathrm{U}$ & & & & & \\
\hline & \multirow{3}{*}{ Cesium-137 } & \multirow{3}{*}{$\mathrm{pCi} / \mathrm{g}$} & 064758-01 & $0.428 \pm 0.0591$ & 0.0164 & 0.0336 & & 0.50 & 0.11 & 0.43 & 0.62 & $0.22 \%$ \\
\hline & & & 064758-02 & $0.441 \pm 0.04$ & 0.00994 & 0.0204 & & & & & & \\
\hline & & & $064758-03$ & $0.621 \pm 0.0648$ & 0.0105 & 0.0215 & & & & & & \\
\hline & \multirow{3}{*}{ Potassium-40 } & \multirow{3}{*}{$\mathrm{pCi} / \mathrm{g}$} & 064758-01 & $28.8 \pm 1.98$ & 0.12 & 0.254 & & 29.87 & 1.01 & 28.80 & 30.80 & $0.03 \%$ \\
\hline & & & 064758-02 & $30.8 \pm 2.24$ & 0.0841 & 0.177 & & & & & & \\
\hline & & & 064758-03 & $30 \pm 2.09$ & 0.0803 & 0.168 & & & & & & \\
\hline & \multirow{3}{*}{ Uranium } & \multirow{3}{*}{$\mu \mathrm{g} / \mathrm{g}$} & 064758-01 & 0.509 & 0.00596 & 0.0398 & & 0.54 & 0.03 & 0.51 & 0.57 & $0.06 \%$ \\
\hline & & & 064758-02 & 0.573 & 0.00599 & 0.0399 & & & & & & \\
\hline & & & 064758-03 & 0.533 & 0.00584 & 0.0389 & & & & & & \\
\hline
\end{tabular}

Notes: $\quad \mathrm{pCi} / \mathrm{g}=$ picocurie per gram

$\mu \mathrm{g} / \mathrm{g}=$ microgram per gram

$\mathrm{U}=$ The analyte was analyzed for, but not detected, below this concentration. For organic and inorganic analytes the result is less

than the effective decision level. For radiochemical analytes the result is less than the decision level.

$\mathrm{X}=$ Preseumptive evidence that analyte is not present.

Std Dev $=$ Standard deviaition

$\mathrm{CV}=$ Coefficient of variation 
TABLE A-7. TLD Measurements by Quarter and Location Class for Calendar Year 2004

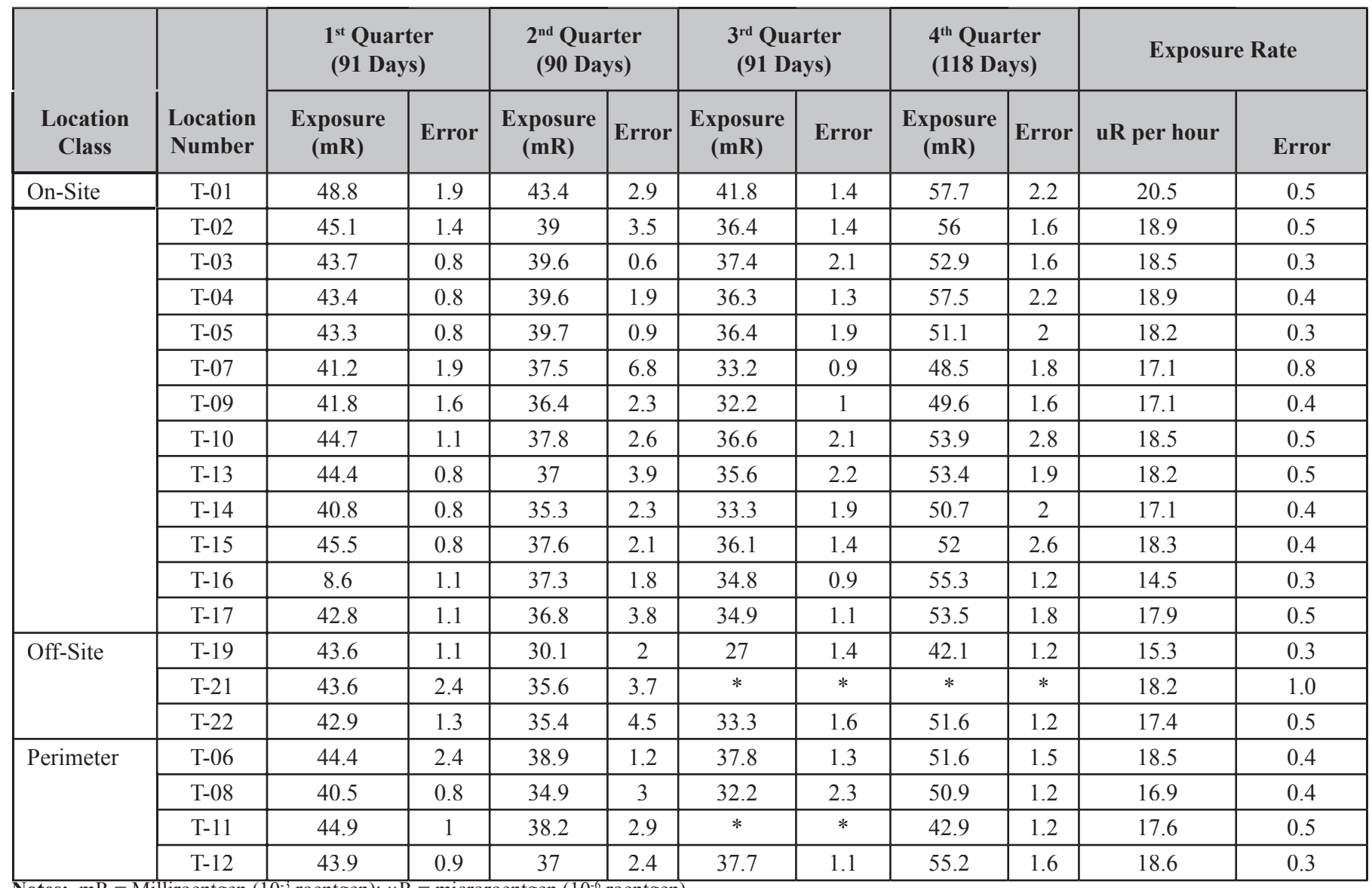

Notes: $\mathrm{mR}=$ Milliroentgen $\left(10^{-3}\right.$ roentgen $) ; \mu \mathrm{R}=$ microroentgen $\left(10^{-6}\right.$ roentgen $)$

* TLD lost, stolen, not exchanged, or data invalid and not used in calculation of average exposure rate 
This page intentionally left blank. 
TABLE A-8. Summary TLD Results for Calendar Year 2004, Tonopah Test Range

\begin{tabular}{|l|c|c|c|c|c|c|}
\hline $\begin{array}{c}\text { Location } \\
\text { Class }\end{array}$ & $\begin{array}{c}\text { Number of } \\
\text { Locations }\end{array}$ & $\begin{array}{c}\text { Mean } \\
\text { Exposure Rate } \\
\text { (uR/hour) }\end{array}$ & $\begin{array}{c}\text { Median } \\
\text { Exposure Rate } \\
\text { (uR/hour) }\end{array}$ & $\begin{array}{c}\text { Std } \\
\text { Dev. }\end{array}$ & Minimum & Maximum \\
\hline Community & 3 & 17.0 & 16.5 & 1.5 & 15.3 & 18.2 \\
\hline Perimeter & 4 & 17.9 & 18.0 & 0.8 & 17.0 & 18.6 \\
\hline On-Site & 13 & 18.0 & 18.2 & 1.4 & 14.5 & 20.1 \\
\hline
\end{tabular}

Notes: $\mathrm{uR}=$ microroentgen $\left(10^{-6}\right.$ roentgen $)$ 
This page intentionally left blank. 


\section{UNLIMITED RELEASE DISTRIBUTION}

U.S. Department of Energy/NNSA (15 HC/5 CDs)

Sandia Site Office (SSO)

Office of Oversight and Assessments

Attn: Karen Agogino

P.O. Box 5400

Albuquerque, NM 87185-5400

U.S. Department of Energy/NNSA (1)

Nevada Site Office (NS)

Attn: Bruce Hurley

P.O. Box 98518

Las Vegas, NV 89193-8518

U.S. Department of Energy/HQ (2)

Office of Engineering (EM-22)

Attn: James Fiore

19901 Germantown Road

Germantown, MD 20874

U.S. Department of Energy/HQ (1)

Director Office of Independent Oversight and Performance

Assurance (QA-1)

Attn: Glenn Podonsky

1000 Independence Ave. SW

Washington, DC 20585

U.S. Department of Energy/HQ (2)

Office of Facilities Management and

ES\&H Support (NA-117)

Attn: Richard Thorpe and Michael Thompson

19901 Germantown Road

Germantown, MD 20874

U.S. Department of Energy/NNSA (CD only)

Nevada Site Office (NSO)

Attn: Bruce Hurley

P.O. Box 98518

Las Vegas, NV 89193-8518

U.S. Department of Energy /HQ (1)

Attn: Alice Williams

Office of Environmental Projects and Operations (NA-56)

1000 Independence Ave. SW

Washington, DC 20585

Vuong Trinh (1)

Lockheed-Martin Corporation

6801 Rockledge Drive

Mail Stop DM315

Bethesda, MD 20817

U.S. Department of Energy/HQ (3)

Office of Air, Water, and Radiation (EH-41)

Attn: Ross L. Natoli

1000 Independence Ave. SW

Washington, DC 20585
U.S. Department of Energy/NNSA (2)

NNSA Service Center (NNSA/SC)

Environmental Safety and Health Department

Attn: C. Soden

P.O. Box 5400

Albuquerque, NM 87185-5400

John Dietrich (1)

Lockheed-Martin Corporation

6801 Rockledge Drive

Mail Stop DM315

Bethesda, MD 20817

Environmental Protection Agency (1)

Headquarters Office

Ariel Rios Building

1200 Pennsylvania Ave, NW

Washington, DC 20460

Environmental Protection Agency (1)

Region IX Office

75 Hawthorne Street

San Francisco, CA 94105

Environmental Restoration Division (1)

Nevada Site Office (NSO)

Attn: Kevin Cabble

P.O. Box 98518

Las Vegas, NV 81913-8518

Division of Environmental Protection (1)

Attn: Allen Biaggi

333 W. Nye Lane, Room 138

Carson City, NV 89706-0851

Frank Grossman (1)

Nevada Test Site

PO Box 98521

MS NTS 273

Las Vegas, NV 89193

Dan Barkley (1 w/disk)

Government Information Department

Zimmerman Library-UNM

1 University of New Mexico MSC05 3020

Albuquerque, NM 87131-0001

U.S. Department of Energy/HQ (1)

Deputy Assistant Secretary for Office of Corporate Safety and

Assurance (EH-2)

Attn: Ray Hardwick

1000 Independence Ave. SW

Washington, DC 20585 
Environmental Health Administration (1)

Environmental Management Division

Attn: Thomas E. Arizumi

Room 300

919 Ala Moana Blvd.

Honolulu, HI 96814-4920

Adeline Sasaki (1)

Kauai District Health Office

3040 Umi Street P.O. Box 671

Lihue, HI 96766

U.S. Department of Energy/HQ (1)

Office of Core Technical Group (EM-23)

Attn: J. Lehr

19901 Germantown Road

Germantown, MD 20874

Karren Suesz (1)

DOE/SNL Community Resource Information Office

2017 Yale SE, Suite E

Albuquerque, NM 87106

U.S. Department of Energy/HQ (1)

Director Office of Scientific and Technical Information (SC-33)

Attn: Walter Warnick

19901 Germantown Road

Germantown, MD 20874 


\section{SANDIA NATIONAL LABORATORIES, INTERNAL DISTRIBUTION}

\begin{tabular}{|c|c|c|c|c|c|}
\hline & (MS 0141) & A. Blumberg, 11300 & 1 & (MS 1042) & S. Hwang, 6331 \\
\hline 1 & (MS 1454) & M. L. Jones, 14412 & 1 & (MS 1042) & A. Jones, 6331 \\
\hline & (MS 0902) & S. Ward, 10872 & 1 & (MS 1042) & M.L. Miller, 6331* \\
\hline & (MS 0651) & ES\&H Security Record Center, 9612* & 1 & (MS 1042) & J. Payne, 6331 \\
\hline & (MS 0112) & F. Figueroa, 10000 & 3 & (MS 1042) & S. Salinas, 6331* (5 CDs) \\
\hline & (MS 1183) & Norm Nitta, 154191 & 1 & (MS 1042) & R. V. Sanchez, 6331* \\
\hline & (MS 9221) & J. Harris, 8516 & 4 & (MS 1042) & K. Wagner, 6331* \\
\hline & (MS 0899) & Central Technical Files, 8945-1* & 6 & (MS 1043) & ES\&H Library, 6329* \\
\hline & (MS 0899) & Technical Library, 9616* & 1 & (MS 9221) & J. Irwin, 10730 \\
\hline & (MS 1042) & L. Bayliss, 6331 & 1 & (MS 1374) & G. E. Chavez, 6927 \\
\hline & (MS 1042) & J. Bonaguidi, 6331 & 1 & (MS 1185) & R. G. Hay, 1523 \\
\hline & (MS 1042) & C. Fink, 6331 & 4 & (MS 1392) & W. Forston, 2915* (1 CD) \\
\hline & (MS 1042) & J. Guerrero, 6331 & 1 & (MS 1392) & R. A. Smith, 2915* (10 CDs) \\
\hline & (MS 1042) & J. Eckstein, 6331 & 1 & (MS 1392) & V. Gabbard, 2915* \\
\hline & (MS 0890) & H. Herrera, 6335 & 1 & (MS 1183) & A. Lopez, 15419* \\
\hline & (MS 1164) & D. Manning, 154021 & 1 & (MS 1037) & J. Moya, 6330 \\
\hline & (MS 1042) & S. Koss, $6331^{*}$ & 1 & (MS 1050) & B. Forbes, 6327 \\
\hline & (MS 1087) & D. Stockham, 6146 & & & \\
\hline
\end{tabular}

NOTE: *Require published copies of this report. 
This page intentionally left blank. 